Portland State University

PDXScholar

1994

\title{
A Simultaneous Route-level Transit Patronage Model: Demand, Supply, and Inter-route Relationship
}

Zhongren Peng

Portland State University

Follow this and additional works at: https://pdxscholar.library.pdx.edu/open_access_etds

Part of the Transportation Commons, and the Urban Studies Commons Let us know how access to this document benefits you.

Recommended Citation

Peng, Zhongren, "A Simultaneous Route-level Transit Patronage Model: Demand, Supply, and Inter-route Relationship" (1994). Dissertations and Theses. Paper 1159.

https://doi.org/10.15760/etd.1158

This Dissertation is brought to you for free and open access. It has been accepted for inclusion in Dissertations and Theses by an authorized administrator of PDXScholar. Please contact us if we can make this document more accessible: pdxscholar@pdx.edu. 


\section{A SIMULTANEOUS ROUTE-LEVEL TRANSIT}

\section{PATRONAGE MODEL:}

\section{DEMAND, SUPPLY, AND INTER-ROUTE RELATIONSHIP}

by

\section{ZHONGREN PENG}

A dissertation submitted in partial fulfillment of the requirements for the degree of

\section{DOCTOR OF PHILOSOPHY \\ in \\ URBAN STUDIES}

Portland State University

๑1994 


\section{DISSERTATION APPROVAL}

The abstract and dissertation of Zhongren Peng for the Doctor of Philosophy in Urban Studies was presented June 24, 1994 and accepted by the dissertation committee and the doctoral program.

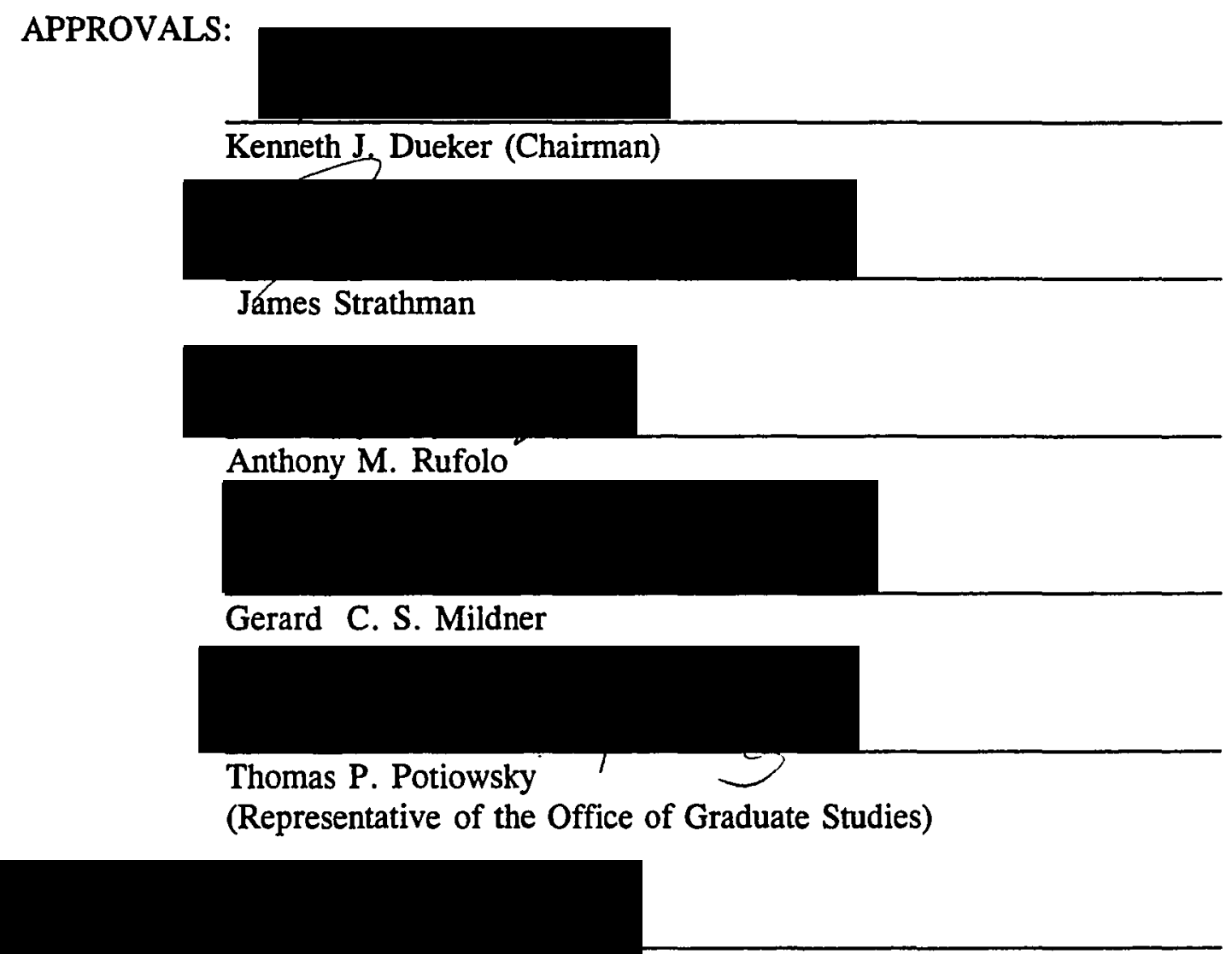

Nancy J. Chapman, Coofdinator, Ph.D. Program in Urban Studies

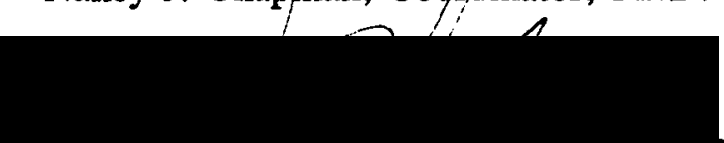

Nohad A. Toulan. Dean, Schoot Urban and Public Affairs

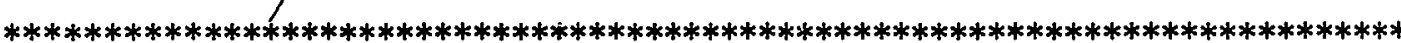

ACCEPTED FOR PORTLAND STATE UNIVERSITY LIBRARY

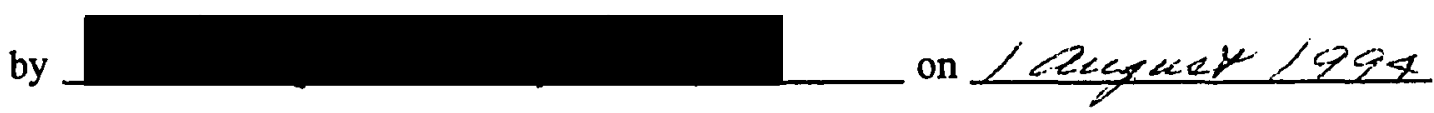




\begin{abstract}
An abstract of the dissertation of Zhongren Peng for the Doctor of Philosophy in Urban Studies presented June 24, 1994.

Title: A Simultaneous Route-Level Transit Patronage Model: Demand, Supply, and Inter-Route Relationship
\end{abstract}

It is observed that transit riders are responding to service changes while transit planning is responding to ridership changes, or that transit patronage and service supply are highly interrelated. It is also noticed that transit riders transfer from route to route, the introduction of new service may draw some riders from the existing routes, which implies transit patronage on a route is also affected by other parallel and intersecting routes. An analytic tool is needed to examine these complex relationships in the transit system. This study has developed a quantitative model by incorporating these interactions into a simultaneous system.

The simultaneity of transit demand, supply and the interrelationship of interroute effects are addressed in a three-equation simultaneous model: a demand equation, a supply equation and an equation for competing routes. These equations are estimated simultaneously using the three-stage-least-squares estimation method. The model is 
estimated at the route-segment level by the time of a day, and by the inbound and outbound directions. Data from Portland, Oregon metropolitan area are used as an extended case study.

The socioeconomic and demographic data are allocated to an one-quarter-miledistance service area around a transit route by utilizing the technique of Geographic Information Systems (GIS). The data allocation significantly reduces the measurement error. Inter-route relationships are also identified using GIS.

The estimation results show that a service change on a route increases the transit patronage on that route, but it also decreases the ridership on its competing routes, so the net effect of that service improvement is smaller than the ridership increase on the subject route. A conventional single-equation model under-estimates the ridership responses on the subject route, and over-estimates the net patronage response.

This study is the first research to discuss the net effects of a service change at the route level. The model can be implemented for system-level policy analysis and route-level service and land use planning. It is especially useful for "what-if" scenario analysis at the route level to simulate the ridership impacts of service and land use changes. 


\section{ACKNOWLEDGEMENTS}

I wish to thank the members of my dissertation committee, Professors Kenneth J. Dueker (Chairman), James Strathman, Anthony M. Rufolo, Gerard C. S. Mildner and Thomas P. Potiowsky for their guidance and encouragement. Professor Dueker has been a constant source of support throughout the course of the research. His advising and encouragement have been invaluable to the study. He carefully and painstakingly read, with insightful comments on, every draft of this dissertation. Professor Strathman offered valuable advice in every stage of the research, particularly the model estimation. Professor Rufolo's constructive comments and suggestions have led to important changes and improvements. Professor Mildner and Potiowsky also made numerous comments in reviewing the draft of the dissertation. Drawing from their extensive knowledge and experience of the subject, the committee has greatly improved the quality of the dissertation.

I would like to thank Ms. Janet Hopper from Tri-County Metropolitan Transportation District of Oregon (Tri-Met) for her contributions to this study. She brought her extensive knowledge about the operation of the Tri-Met system and provided all of the transit ridership and service data. Professors Dueker and Strathman, Ms. Janet Hopper and I have had a weekly discussion on the study for about two years. This research is truly an achievement of team work. 
This study was funded by Transportation Northwest (TransNow) Regional Center under the sponsorship of the Department of Transportation UTC Grant Program and Tri-Met. The digitized transit routes and land use data were provided by METRO of Portland, Oregon.

I am grateful to Richard Gerhart and James Hergert in Tri-Met, for their support and comments to this study; to Professor Kuan-Pin Lin for his helpful suggestions on the development of the simultaneous-equation models. I would also like to acknowledge the assistance at various stage from Cary Lorimor, Ningshen Zhou, Zhen Liu and John Zhao.

Finally, I owe special thanks to Xueqing Zhou, my wife, for her consistent assistance and sacrifice of her time. Her love and support have helped make this dissertation possible.

The contents of this dissertation do not necessarily reflect the views or policies of TransNow, the U.S. Department of Transportation and Tri-Met or any of those of the individuals mentioned above. The author is fully responsible for the views expressed and any errors that remain. 


\section{TABLE OF CONTENTS}

ACKNOWLEDGEMENTS $\ldots \ldots \ldots \ldots \ldots \ldots \ldots \ldots$ i

Chapter 1 INTRODUCTION $\ldots \ldots \ldots \ldots \ldots \ldots \ldots \ldots$

Chapter 2 OVERVIEW OF THE ROUTE-LEVEL TRANSIT

PATRONAGE MODELS $\ldots \ldots \ldots \ldots \ldots \ldots \ldots$

I Comparison of Network and Direct Demand Modeling $\ldots \ldots \ldots$

II Overview of Direct Demand Models . . . . . . . . . . . . . 14

A Cross-Sectional Models . . . . . . . . . . . . . . . 14

B Time-Series Models . . . . . . . . . . . . . . . 16

C A Combination of Cross-Sectional Models and Time-Series Models . . . . . . . . . . . . . . . . . . 20

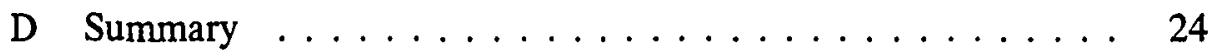

III Problems of Route-Level Transit Patronage Models . . . . . . 26 Problem 1 The Problem of Data Consistency . . . . . . . . 26 Problem 2 Inter-Route Relationship . . . . . . . . . . . . . 28 Problem 3 Simultaneity between Transit Demand and Supply . . 30

Chapter 3 A GIS DATABASE DESIGN AND SPATIAL DATA ALLOCATION $\ldots \ldots \ldots \ldots \ldots \ldots \ldots \ldots \ldots \ldots$

I Introduction $\ldots \ldots \ldots \ldots \ldots \ldots \ldots \ldots \ldots \ldots \ldots$

II Database Requirements of Transit Demand Modeling $\ldots \ldots \ldots 35$

III Spatial and Temporal Transit Database Design $\ldots \ldots \ldots \ldots 38$

IV Data Integration $\ldots \ldots \ldots \ldots \ldots \ldots \ldots \ldots \ldots \ldots$

Count Data Allocation . . . . . . . . . . . . . . 46

Attribute Data Allocation $\ldots \ldots \ldots \ldots \ldots \ldots \ldots$

$\mathrm{V}$ Inter-Route Relationships $\ldots \ldots \ldots \ldots \ldots \ldots \ldots \ldots$

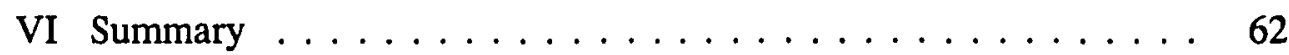


Chapter 4 SPATIAL AND TEMPORAL VARIATIONS OF TRANSIT

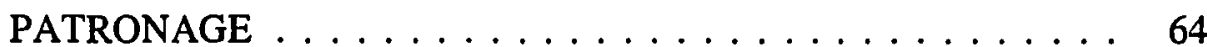

I Temporal Variations of Transit Ridership $\ldots \ldots \ldots \ldots 4$

II Spatial Variations of Transit Ridership . . . . . . . . . . . . 68 Ridership Variations Among Different Route Types . . . . . . . 68 Directional Variations . . . . . . . . . . . . . . 77 Variations Among Fare Zones . . . . . . . . . . . . . . . 79

III Summary $\ldots \ldots \ldots \ldots \ldots \ldots$

Chapter 5 AN ANALYSIS OF A SIMULTANEOUS TRANSIT SYSTEM $\ldots \ldots \ldots \ldots \ldots \ldots \ldots \ldots$

I Introduction $\ldots \ldots \ldots \ldots \ldots \ldots \ldots$

II Simultaneity of Transit Demand and Supply . . . . . . . . . . . . . . 90

Transit Demand . . . . . . . . . . . . . . . . . . . . 92

Transit Supply . . . . . . . . . . . . . . . . . . . . 97

Service Adjustment Process . . . . . . . . . . . . . . . . 101

III Inter-Relationships among Transit Routes $\ldots \ldots \ldots$. . . . . . 103

IV Summary $\ldots \ldots \ldots \ldots \ldots \ldots$

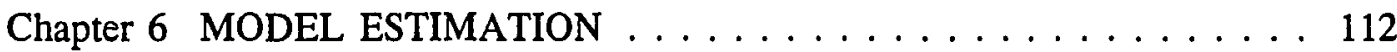

I Models for Inbound Direction . . . . . . . . . . . . . . 113

Demand Equations . . . . . . . . . . . . . . . 114

Supply Equations . . . . . . . . . . . . . . . . . . . 119

Equations for Competing Routes . . . . . . . . . . . . . . 122

II Models for the Outbound Direction . . . . . . . . . . . . . 125

Demand Equations . . . . . . . . . . . . . . . . 125

Supply Equations . . . . . . . . . . . . . . . . . . . . 129

Equations for Competing Routes . . . . . . . . . . . 132

III The Comparison Between A Single-Equation Model and A

Simultaneous-Equations Model . . . . . . . . . . . . 133

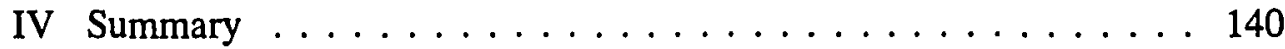


Chapter 7 APPLICATIONS OF THE MODELS: SYSTEM LEVEL POLICIES AND ROUTE-LEVEL PLANNING . . . . . . . . . . 143

I System Level . . . . . . . . . . . . . . . . . . . . . . 143

A Transit Service Planning . . . . . . . . . . . . . . . . . . . 144

B Land Use Planning . . . . . . . . . . . . . . 146

II Route Level . . . . . . . . . . . . . . . . . . . . . . 147

A Existing Route Analysis . . . . . . . . . . . . . 147

B New Route Analysis . . . . . . . . . . . . . . . 150

C Transit-Intensive Corridor Analysis . . . . . . . . . 151

III Application Process of Route-Level Patronage Estimate . . . . . . 154

IV Summary $\ldots \ldots \ldots \ldots \ldots \ldots \ldots \ldots \ldots \ldots \ldots$

Chapter 8 CONCLUSIONS AND IMPLICATIONS FOR FUTURE RESEARCH . . . . . . . . . . . . . . . . . . 159

REFERENCES . . . . . . . . . . . . . . . . . . . . . . . . 167

APPENDIX A SAMPLE OF ROUTE-SEGMENT LEVEL

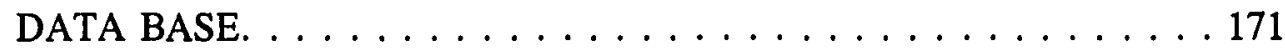




\section{LIST OF TABLES}

Table

Page

3.1 Attribute Data and Their Associated Spatial Features . . . . . . . . 40

3.2 Comparisons of Population Allocation Results Using Different Methods at the Transit Route Segment Level . . . . . . . . . . . . . . . . . . . 48

4.1 Ridership During Time Periods of a Day -- Spring $1990 \ldots \ldots 5$

4.2 Daily Ridership and Services by Route Typology . . . . . . . . . . . . 71

4.3 Transit Ridership at Time Period of a Day by Directions . . . . . . . 78

4.4 Transit Ridership on Fare zones . . . . . . . . . . . . . . . 81

$5.1 \quad$ Passenger Loading Standards . . . . . . . . . . . . . . . . . . . . 99

5.2 Policy Headways for Weekdays . . . . . . . . . . . . . . . . 100

5.3 Determinant Variables for Demand and Supply Equations in Different Time Periods and Directions . . . . . . . . . . . . . . . . . . 110

6.1 Demand Equations for Inbound Direction $\ldots \ldots \ldots \ldots$

6.1a Coefficients for Population in Inbound Demand Models . . . . . . . . 117

6.2 Supply Equations for Inbound Direction . . . . . . . . . . . . 121

6.3 Equations for Competing Routes for Inbound Direction . . . . . . . . . 124

6.4 Demand Equations for Outbound Direction . . . . . . . . . . . 126

6.5 Supply Equations for Outbound Direction . . . . . . . . . . . . . 130

6.6 Equations for Competing Routes for Outbound Direction . . . . . . . 133 
6.7 Iterative Process of Estimating Ridership Impacts of One Unit of Service Change ............................ 135

6.8 Net Effects of Service Changes of Additional One Hundred Seats on an Inbound Route in the Morning Peak Period . . . . . . . . . . . 138

7.1 Coefficients for Interaction Variables of Fare Zone Dummies with $\operatorname{LOS}_{\mathrm{i} z}$ for Inbound Routes in the Morning Peak Period . . . . . . . . 145

7.2 Coefficients for Interaction Variable of Fare Zone Dummy with Population for Inbound Routes in the Morning Peak Period . . . . . . 146

7.3 Ridership Impacts of Headway Change From 24 min. to 17 min. . . . . 153

7.4 Ridership Impacts of 1000 Person Increase on Line $56 \ldots \ldots$. . . . 154

7.5 Ridership Impacts of Headway Change And Population Changes . . . 154 


\section{LIST OF FIGURES}

$\begin{array}{lll}\text { Figure } & \text { Page }\end{array}$

3.1 Spatial Data Allocation $\ldots \ldots \ldots \ldots \ldots \ldots \ldots \ldots \ldots$

3.2 Cross-Route Relationship: Complementary and Competing Routes . . . 60

4.1 Transit Routes and Fare Zones in Portland, Oregon (1990) . . . . . . 80

5.1. Internal Variable Flow in A Transit System $\ldots \ldots \ldots \ldots \ldots$

5.2. General Factors Influencing Transit Demand and Supply . . . . . . 88

6.1. Estimated Simultaneous Effects of Endogenous Variables. . . . . . 135

6.2. The Impacts of Employment Changes upon Endogenous Variables $\ldots 137$ 


\section{CHAPTER 1 INTRODUCTION}

Currently, route-level transit service planning relies heavily on the accumulated experience and judgment of transit planners, aided by some ad hoc "rule-of-thumb" methods (Lago, 1991; Stopher and Mulhall, 1992). Route configuration and service are often planned on a trial-and-error basis and subsequently changed based on observed ridership (Multisystems, Inc., 1982).

A recent survey shows that most transit planning agencies use subjective judgement as a transit patronage forecasting tool, together with some quantitative methods such as elasticity analysis and regression models (Stopher and Mulhall, 1992). Few agencies rely solely on mathematical models. The heavy reliance on subjective judgement indicates that the available models have not reached the level of reliability and accuracy sufficient for the needs of transit planners, and that there is a significant need for new and better methods for route-level ridership estimation.

Different types of quantitative models have been developed to estimate route-level transit ridership. Most of them are single equation linear regression models that treat routes as independent from each other. Ridership is estimated based on the coefficients or elasticities of independent variables, especially transit service variables such as service frequency and hours of services. When transit agencies increase transit 
service, they expect an increase in transit ridership as the models predict. However, they are often disappointed if it turns out that the change in ridership corresponding to an increase in service is a shift of current transit riders among routes, and the net change in transit patronage is negligible, far less than what the model predicted.

There are many reasons for the poor performance of route-level transit demand models in predicting ridership changes. Long-term socioeconomic changes, such as the gradual decentralization of employment and population, may invalidate parameter estimates in the models. However, if the model is used as a short-term (less than five years) forecast tool, this long term factor will have little impact on the model's performance, because decentralization is usually a gradual process. The major weaknesses of the transit demand model at the route level are lack of consistent data, ignorance of inter-route relationship, and the lack of the simultaneous analysis of transit demand and supply.

An important factor to an accurate model is good data. The key question is whether the right thing has been measured. Estimation of ridership on a specific route requires route-specific socioeconomic and demographic data. Using socioeconomic data that are not route-specific or are inconsistent with the area that is served by the route to estimate route ridership will inevitably result in errors.

The second factor affecting model performance is the inter-route relationship. The transit system is a network, it is designed to facilitate riders to transfer from one route to the other. In addition, many transit routes traverse the same road or on closely parallel roads, which provide transit users choices of routes. In other words, in a transit 
network system, routes can be complementary or competing with each other. A service change in one of these complementary and competing routes will have impacts on the other related routes. Models that treat these routes as independent, not taking account of interrelationships among routes will generate biased ridership estimation, at both the route level and the system level.

The third factor affecting the performance of a model is the simultaneity of transit demand and supply. The current spatial distribution of transit service and ridership among routes is a combination of transit demand and transit supply. Transit ridership is responding to transit service changes, while transit planners are responding to ridership changes with adjustment of planned services. In a single-equation regression model using transit service level as a regressor, a simple ordinary least square (OLS) estimate will result in a coefficient estimate for the transit service variable. That estimated coefficient is a combined effect of transit demand responses to service changes and transit planners' responses to ridership changes. If the service variable coefficient was treated as the only contribution of service changes to ridership changes, the demand response to transit service changes would often be over-estimated. Such models often prove to be overly sensitive to frequency of service (Multisystems, Inc., 1982).

The primary objective of this dissertation is to address these three issues that affect the performance of route-level transit demand models by using the techniques of Geographic Information Systems (GIS) and simultaneous-equations models. GIS analysis is a powerful tool in addressing the spatial data consistency and inter-route 
relations. The simultaneous-equations model is to be used to deal with the simultaneity between transit demand and supply, as well as the simultaneity among related routes.

Data from the Tri-County metropolitan transportation district of Oregon (TriMet) service area in Portland, Oregon are used as an extended case study. Tri-Met is the transit agency that provides transit service to the Portland, Oregon metropolitan area. It has detailed transit ridership and transit service data.

Like many other transit agencies, service planning at Tri-Met is based mainly on planners' subjective judgement, guided by some "rule-of-thumb" standards. Service on a route is scheduled according to the loading standard and some policy headways (Tri-Met, 1989). For high ridership routes and during peak hours the service is planned and adjusted based on the loading standard so that the bus is not too crowded. For low ridership routes and during off-peak hours, the service is planned based on the standard of policy headway -- the minimal frequency of operation on each transit route. New routes and new services are planned based on the requests from communities and residents, as well as the availability of budget.

Forecasting ridership response to proposed service changes for existing routes is based on planners' experience and judgement, combined with some rule-of-thumb fare and service elasticities. Ridership forecasting for new routes uses ridership figures from similar route. These professional judgement methods are sometimes fairly accurate if the planners and schedulers are very experienced and have good knowledge about the region. But these methods are generally nonreplicable. The same individual may provide different estimates of ridership changes at different times, and different 
individuals would offer different estimates.

These judgements and elasticity methods are challenged when they perform poorly. For example, transit service and population have increased over last three years in Portland metropolitan area, but ridership did not increase accordingly. Tri-Met is under great pressure to explain why this is the case, and was questioned whether the service was provided efficiently. This demonstrates the need to have a reliable quantitative model as a tool to estimate ridership responses to service and other factor changes.

A quantitative model should be responsive and sensitive to a variety of service changes, as well as land use changes. The service changes include service frequency changes, extending or reducing hours of service, expanding or shortening route length, short-line operations and new route development. Land use change should include changes of land use density, because land use density is increasingly used as a transportation policy by some local and state governments in the U.S., especially in the State of Oregon.

In addition, the model should be capable of estimating ridership changes not only on the route in which the service is changed, but also on its related routes. In other words, the model should be able to estimate ridership impact on the route that has service changes, and to estimate the net effect of that service changes taking account of the interrelationships among its related routes, because some increased patronage on that route may be existing riders shifting from other existing routes.

These requirements are addressed in the models developed in this dissertation. 
Although the coefficients are applicable for the Tri-Met service area, the methodology can be applied to other regions as well.

This dissertation contains seven major analyses to develop a route-level transit ridership model, which will be presented in the subsequent chapters. Chapter 2 reviews the previous transit demand modeling activities and discusses some of the problems and difficulties faced in route-level modeling: data consistency, inter-route relationship and the simultaneity of transit demand and supply.

To achieve data consistency, Chapter 3 discuss the data requirements of a routelevel model, and describes how data consistency can be achieved among different data sets by the spatial and attribute data allocation using GIS. It also sheds some lights on a future GIS database design to serve transit demand modeling, and how different allocation methods result in different data accuracy.

Chapter 4 analyzes the temporal and spatial variations of transit patronage in Tri-Met service areas. Transit ridership variations in 1990 on different time period of a day, on different route types, on different fare zones and different directions are analyzed. This chapter also explain the reasons behind these temporal and spatial variation, which derives a need to deal with these variations differently in the models.

Chapter 5 addresses the issues of the simultaneity of transit demand and supply, and the simultaneity of ridership and service impacts among interrelated routes. A simultaneous decision making process of transit demand and supply is examined. Factors that affecting the demand for transit services and standards that are used in the service planning are discussed. GIS is used to analyze the relationships of transit lines 
in the transit route network. A simultaneous-equations model is developed to integrate the simultaneous system of transit demand and supply, and the inter-route relationship.

Based on the model developed in Chapter 5, Chapter 6 calibrates the simultaneous-equations models using observed ridership and service data in five time periods of a day and two directions, therefore ten models are calibrated altogether. Three stage least squares (3SLS) method is used to estimate the models. The OLS estimation results are compared with the 3SLS estimates. A simulation is made to trace the ridership response on a route with an 100 seats increase and on its related routes. The net effects of a service change can be derived from this simulation.

Chapter 7 extend the discussion on Chapter 6 about potential implementations of the models. It discusses the implementation strategies and limitations for transit service planning for the system level policy analysis and route level ridership estimations.

The last chapter provides a summary of the thesis, and briefly discusses the future research on route-level transit patronage modeling. 


\section{CHAPTER 2}

\section{OVERVIEW OF THE}

\section{ROUTE-LEVEL TRANSIT PATRONAGE MODELS}

Models developed to estimate route-level transit ridership can be classified as two general approaches. One is the traditional Urban Transportation Planning System (UTPS) approach or network approach which treats transit routes as a network system, and uses a four-step modeling process (trip generation, trip distribution, mode choice, and trip assignment) to derive ridership for individual transit routes. The other approach is the direct demand modeling. It usually uses a regression model, regressing ridership at the individual route, route segment, or bus stop level against the determining factors of transit ridership within the transit route service areas.

Both of these two approaches have been applied in transit ridership forecasting. These two approaches serve different purposes and have their advantages and disadvantages. This chapter will briefly describe and compare these two approaches and discusses the problems and difficulties faced in route-level transit ridership estimate modeling.

\section{COMPARISON OF NETWORK AND DIRECT DEMAND MODELING}

The network or UTPS model is a large-scale and long-range transportation 
planning tool. It focuses on travel origins and destinations, traffic flows and equilibrium assignments to the network. The UTPS model begins with trip generation estimation. Potential trips that can be generated at the starting point (or production point), and the potential trips attracted to the end point (or attraction point) are estimated based on the land use characteristics like households and employment. These potential trips are distributed among traffic zones. This process is called trip distribution, the trip volumes between zones is usually estimated by using gravity models. The traffic volume between two zones is positively related with the trip productions and attractions of each zone, and negatively related with travel impedance or disutility, such as distance, travel time, and out-of-pocket costs, between the two zones. After the traffic volume is estimated between each traffic zone pair, the next step is to determine what mode the travelers would use based on the travelers' preferences and affordability of time and money costs. It is referred as a modal choice, or modal split model. The final step is the trip assignment, that is, to determine the trip-makers' likely choice of paths between all zones and then to estimate the resulting flows on the individual links.

The network approach is capable of estimating modal split at the zone-to-zone level and assigning transit trips to individual routes. It is also able to trace the systematic consequences of isolated changes in the transportation system. A transit service change in a specific route will result in estimated transit patronage changes in other routes.

There are a couple of applications using this network approach in the literature. The Transit Ridership Forecasting Model (TRFM), a transit network package, was 
developed for transit forecasting within the UTPS context (Horowitz, 1984; Horowitz and Metzger, 1985). The TRFM is essentially a simplified UTPS model using the concept of "windowing and focusing" that preserves detail of a selected route, while greatly simplifying the configuration of the remainder of the network. It makes several assumptions in order to simplify procedures. The first assumption is that transit riders make at most one transfer because transit riders want to make as few transfers as possible. This assumption permits the model to consider only the route of interest and its immediate connecting routes, while other routes can be ignored. The second assumption is that the ratio of bus speed and auto speed is always constant, which eliminates the necessity of considering the highway network. The third assumption is that there is only a single destination for most transit trips, which greatly simplifies trip assignment. Finally, TRFM assumes that most transit riders are captive riders and that captive riders are insensitive to service changes and can be assigned directly to the subnetwork. In its later refinement, the transit service area rather than traffic analysis zone is suggested to be used as a basic measuring unit because a traffic analysis zone can contain all or part of a transit route, and a multi-path assignment algorithm rather than the all-or-nothing assignment algorithm is suggested as an improvement (Horowitz and Metzger, 1985).

Another application of using the network model is developed by Nickerson, Meyburg and Turnquist (1983). The model incorporates the observed transit ridership volume into the standard UTPS model. A sequence of simple trip generation, trip distribution and modal split models are used to generate trip-purpose specific trip 
tables. These trip tables and observed transit link volumes are used in a linear programming model which serves as a correction mechanism. The model can gain accuracy by using the observed ridership information on transit links. But its ultimate accuracy is determined by the trip-purpose specific trip tables derived from the first three component models.

Despite of these application efforts, there are several limitations of the network or UTPS-type models, especially when they are used in route-level estimation. Among those are the following:

1. The UTPS-type model focuses on large-scale and long-range regional transportation planning. It is incapable of providing sufficiently detailed information to guide small-scale operational improvements like transit frequency changes (Papacostas, 1987; Stopher and Mulhall, 1992). It often does not contain variables that relates to the transit level of service and is therefore not sufficiently sensitive to transit service changes. A marginal service change on one route will have virtually no impact on its ridership based on the UTPS model.

2. This UTPS approach is technically complex, and requires large amount of data and computing time. This makes application difficult in transit service planning. Although it can sometimes be scaled down by a process of "windowing and focusing" to apply in microcomputers, significant data and modeling problems still exist, and the "windowing and focusing" process would result in a larger amount of errors than more detailed models (Horowitz, 1984).

3. The weakest point of the UTPS type model is its inaccuracy at the route 
level. The margin of error associated with this method often significantly exceeds the likely change in transit ridership (Multisystems, Inc. 1982). Traffic volumes tween traffic zones generated from the trip distribution model like gravity model are not observed volume. They are generated from the model. This generated traffic distribution tables include errors. Furthermore, this generated trip disiribution table needs to be assigned to individual road in the network. The trip assignment in the UTPS-type models, whether using the all-or-nothing algorithm or multipath assignment procedure based on the concept of frequency split that assigns the trips to the bus routes according to their respective frequencies (Horowitz, 1987), often results in over-assigned riders on some routes and under-assigned riders on others (Prashker, 1988). While this is not a problem at the system level, prediction accuracy at the route level suffers. Horowitz and Metzger (1985) cited the Milwaukee case study, in which the 14 routes with the lowest actual volumes had a root mean square (RMS) error of 75 percent of average ridership. The Portland prototype model also generated overall errors of 49 percent (Tri-county Metropolitan Transit District, 1983).

Because of these disadvantages of the traditional UTPS model, very few transit operators are currently using this method in their route level service planning (Stopher and Mulhall, 1992).

While the network approach focuses on the travel origins and destinations, and the equilibrium of the network system, the direct demand model approach focuses on the ridership on a specific route. It utilizes the observed transit ridership and regress it against transit service variables and socioeconomic and demographic characteristics 
in the transit route service area.

In contrast to the UTPS-network model, the direct demand model is considered more appropriate for short-range route-level service planning. A major advantage of the direct demand model is that it is more sensitive to transit service changes and therefore suitable for short-run "what-if" scenario analysis. The direct relationship between level of service, land use patterns and transit ridership can be used directly for transit service and land use planning.

Another advantage of the direct demand model is the availability of the transit operating data which makes it easy to conduct ex post analysis of the consequences of transit service and land use changes.

The third advantage of the direct demand models, according to some previous studies, is their precision at the route level. Kyte, Stoner and Cryer (1988) report that errors in ridership forecasts for the route level direct demand model varies from $2.3 \%$ to $17.0 \%$, with most being less than $7 \%$.

On the negative side, the major disadvantage of the direct demand models lies in the isolation of individual routes from other routes in the transit network. It does not take into account the inter-route relationship. It treats individual routes as independent from each other, and assumes a service change in one route does not have any impacts on its related routes. These assumptions result in biased ridership estimate both in the route level and aggregated system level.

Considering the relative merits of the two basic approaches in their applications in route-level transit forecasting, the direct demand approach has the advantages of 
greater sensitivity of route-specific determinants of ridership, better estimation precision and the comparative ease of application over the large-scale, UTPS-type models. The direct demand model approach is applied in this dissertation for estimating route level transit patronage.

\section{OVERVIEW OF DIRECT DEMAND MODELS}

Direct demand models estimate the variance of demand and supply of transit services over space and time by using regression models. There are three major categories in the direct demand modeling: cross-sectional, time-series, and the combination of the two.

\section{A. Cross-Sectional Models}

Cross-sectional models examine the relationship between transit use and a range of characteristics of transit service and socioeconomic variables over many transit routes for a given point in time. They are based on the assumption that these relationships are constant over different bus routes, or at least over different routes of the same type. The estimated parameters of these variables can be applied over different routes and new routes.

The most common form of cross-sectional model is the single linear regression model. The transit ridership is usually modeled as a function of a set of explanatory variables, such as level of transit service, demographic and land use conditions, and the socioeconomic characteristics of the residents in a geographic area. Agrawal (1978) 
specifies four independent variables in a linear regression analysis: average adult fare, jobs, vehicle miles of service, and a miscellaneous events factor. He found that these variables were strongly correlated with transit ridership.

Some linear transformations, like logarithmic transformations, provide alternatives in model specifications and estimations. A study by Ecosometrics, Inc. (1976) for Pennsylvania Department of Transportation (PennDOT) found that the logarithmic transformations outperformed the linear forms, both in terms of fit and the statistical significance of the regression coefficients.

Lutin et al (1981) test a nonlinear specification of a regression model, and found the nonlinear models offered more explanation of variance. But the choice of a nonlinear model was criticized as being lack of theoretical support (Stopher and Mulhall, 1992).

The cross-section models can account for a wide variety of transit and land use policy variables and other exogenous variables which directly affect transit patronage. They can be used to make a detailed analysis of some transit ridership determinants. A cross-sectional model captures the variance over a wide geographic area, and it may be applicable over a wide range of situations (Multisystems, Inc., 1982). The cross-sectional models are often considered as an indication of "long run adjustment" (American Public Transit Association, 1991). The cross-sectional estimates have some advantage in forecasting structural changes in demand, but they cannot be used to explain the long-range temporal variance of transit ridership. 


\section{B. Time-Series Models}

Time-series models are developed to estimate transit patronage changes for an area or a single route as service and other variables change over time.

A significant characteristic of public transit use is its variation over time. Time series analysis is used to incorporate this temporal phenomena in regression analysis for forecasting purposes, based mainly on the past performance of transit ridership variations, and some policy input variables, such as level of services and some socioeconomic characteristics. Many other exogenous variables, which are major determinants of transit ridership, cannot be included in time series models because of the lack of systematic and consistent data. Therefore, many time-series analyses may be accurate in forecasting transit ridership over a very short time period, but may not be accurate over a long time period. In addition, time-series analysis is not very sensitive to policy changes because of limited policy input variables.

There are basically three different kinds of conventional time series analysis used in transit demand modeling: elasticity analysis, trend analysis, and ARIMA models.

\section{Elasticity Analysis}

Elasticity analysis in transit demand modeling measures the impact of changes in the fare and the level of service on transit patronage. There are two forms of elasticity: point elasticity, which measures the percentage change of ridership to a fare or service change at a specific point on the demand curve; and arc elasticity, which 
measures the percentage change between two points along a curve. Most elasticity analyses compute arc elasticities, because computation of a point elasticity requires knowledge of the true functional form of the relationship between transit demand and fare or services (Multisystems, Inc. 1982).

The commonly cited example of an elasticity analysis is Curtin's work. Curtin examined the ridership changes before and after fare changes on a variety of transit systems, and concluded the fare elasticity of transit demand is -0.33 ; i.e., a one percent increase of fare will result in a 0.33 percent drop in ridership (Curtin, 1968). Following Curtin, a number of elasticity analyses has been conducted (See Ferreri, 1979, Mayworm, et al, 1980, American Public Transit Association, 1991). Mayworm, et al's (1980) extensive survey of transit fare and service elasticities in 1980 indicated that both point and arc elasticities with respect to fare and service levels are inelastic.

The elasticity calculated from before and after a fare or service change is applicable when only a single level of variable of fare or service changes, holding other variables constant. If other determinants of ridership are also changed and are not controlled, an incorrect estimate of the elasticity may result. The ridership changes over time may be due to factors other than the attribute measured. In this case, a transfer function model (discussed later in this chapter) is a superior choice to the traditional elasticity estimating models (American Public Transit Association, 1991).

Elasticities are unique to each city or region, or even each transit route type. The elasticity model can not be used to estimate ridership for a new route. An elasticity from a "similar route" has to be borrowed to estimate ridership on the new route. 
Furthermore, the route level elasticity cannot be applied when the route configuration is changed.

\section{Trend Analysis}

Some trend analysis in the literature uses early performance to project route level transit ridership (Foerster \& Imlay, 1989). Most models are bivariate regression models, using time as the only independent variable. A linear model is the most commonly used form. Other forms include probit-, logit-, and power-function and linear-log models.

Trend analysis can be used as a very "quick and dirty" method to estimate transit ridership over a short period of time, assuming other factors are stable. It can not be used when other variable changes. It is not sensitive to any policy variables like fare or service changes.

Since it is easy to calibrate and estimate, trend analysis is still applied in some transit planning agencies (Stopher \& Mulhall, 1992).

\section{ARIMA MODEL}

The integrated autoregressive-moving average (ARIMA) model is a more sophisticated method using time-series data in transit ridership forecasting. It uses only the past transit patronage to forecast future ridership. It is simply a more sophisticated trend analysis.

ARIMA models have been used to study the effects of intervening events such 
as transit strikes and fare changes on transit ridership changes (Harmatuck, 1975; and Wang, 1981). They are also used to forecast future traffic volume and transit ridership (Nihan \& Holmesland, 1980; and Wang, Ling \& Skinner, 1982).

ARIMA models are atheoretical methods. The development of an ARIMA model is an art and requires experience. It may perform well in forecasting transit ridership over a very short time. In fact, some studies found that using ARIMA models outperforms many other more sophisticated structure-typed models in short-term forecasting (Naylor, et al, 1972; Nelson, 1973; and Nihan \& Holmesland, 1980). However, its long-term forecasting is very unreliable.

In addition, ARIMA model is insensitive to exogenous and policy variables. If other conditions that affect the transit variable changes, the ARIMA model cannot perform well. It is useful in a relatively stable environment over a short period of time.

It is important to note that an ARIMA model, or any time-series analysis based solely on past performance of transit ridership, is more applicable at the system level, i.e., the whole transit system in a city or a metropolitan area. It should be used cautiously at the route level, because most transit route configurations change over time, even though the route names may remain the same. An ARIMA model could not be used when the route configuration changed. This problem is mostly ignored in the literature, but it is too important to be avoided. The route configurations change over time, some are shortened, some are extended, and some are rerouted. The configuration changes make the time-series analysis inappropriate because the timeseries analysis requires the ridership data come from exactly the same route over time. 


\section{A Combination of Cross-Sectional Models and Time-Series Models}

Cross-sectional models capture variations across different routes in space, and time series models capture variations of transit ridership over time. A combination of cross-sectional models and time-series models can capture variations of ridership in time as well as in space. While this approach combines the advantages of both, it may combine the problems of both as well.

The combination of cross-sectional and time-series analysis in transit demand modeling takes two common forms: the pooled time-series analysis and the transfer function.

\section{Pooled Time-Series Analysis}

In many transit planning agencies, observations for transit ridership are available for some individual routes over a period of time. A single univariate time-series analysis is not appropriate because the route configuration has changed and the time span is not long enough for conventional time series techniques. A cross-sectional analysis lacks the ability of reflecting temporal and dynamic effect. A pooling of time series and cross-sectional is particulariy useful here to reflect the ridership variation between different routes over time.

Several studies in transit demand modeling have used pooled time-series analysis (Alperovich, Kemp \& Goodman, 1977; Gaudry, 1975; Ferguson, 1991; and McLeod, et al, 1991). Most of them are systemwide aggregate models (Gaudry, 1975; Ferguson, 
1991; and McLeod, et al, 1991). At the system level, heteroscedasticity is not a serious problem, since the data are aggregated in the city or the whole metropolitan area. The variances of the error term could be considered as being constant. Autocorrelation is a more serious problem. It is often corrected by considering the first-order or $\mathrm{n}$-th order auto-regressive process (Gaudry, 1975; and Ferguson, 1991). Some historical incidents like a gasoline shortage and a transit worker strike are treated as dummy variables.

Alperovich, Kemp \& Goodman (1977) use a set of dummy variables to distinguish routes or route groups and seasons in their route level transit demand modeling. A historical incident is also represented by a dummy variable. The dummy variables are used to distinguish the unique effects of route type and points in time as if these were surrogates for systematic effects observed in space and in time.

It should be noted, however, the effect of dummy variables is "fixed" conditionally in the intercept term. As Sayrs (1989) points out, "The intercept is not an explanation for the between-unit variance or the variance over time. The intercept is simply a characterization of the variance that attempts to minimize the bias in the 'true' explanation (P. 28)." The use of a time-related dummy variable has not made any assumptions about correlation in time periods such as first-order autoregression. Therefore, using a dummy variable can not detect the problem of autocorrelation.

At the route level, a pooled time-series analysis is even more difficult than at the system level. More detailed route-level data are required. For those routes with configuration changes, a digitized yearly route map is needed. Digitizing those route 
map over years is a very time-consuming task. Furthermore, the time-series micro-level socioeconomic and demographic data, such as in the census tract level, are required to be allocated into individual transit routes.

\section{Transfer Function Models}

The error term in the pooled time series analysis can be decomposed into three components: error systematic to space (cross-section), error systematic to time, and error systematic to both. A space-related dummy variable can be used to capture the error systematic to space, and therefore, can help detect the problem of heteroscedasticity. A time-related dummy variable, however, cannot detect the problem of autocorrelation. The error component systematic to time is left to be modeled. A transfer function model is the one to take into account these error components to forecast future behavior of the dependent variables.

A transfer function, or a multivariate autoregressive-moving average (MARMA) model is composed of two parts. The first part is a structural regression model which is based on theoretical construction. The second part is the time-series analysis (ARIMA model) which analyzes the residuals of the structural part (Pindyck and Rubinfeld, 1991). It takes the following general form:

$$
\mathrm{y}_{\mathrm{t}}=\alpha_{0}+\alpha_{1} \mathrm{X}_{1 \mathrm{t}}+\alpha_{2} \mathrm{X}_{2 \mathrm{t}}+\ldots+\alpha_{\mathrm{n}} \mathrm{X}_{\mathrm{nt}}+\phi^{-1}(\mathrm{~B}) \theta(\mathrm{B}) \eta_{\mathrm{t}}
$$

Where $y_{t}$ is a dependent variable, $X_{n t}$ are a set of independent variables, and $\alpha_{n}$ are corresponding coefficients of $X_{n t}$. The second part $\phi^{-1}(B) \theta(B) \eta_{t}$ is an ARIMA model 
that can help "explain" the unexplained variance in the structural model. The transfer function is likely to provide a better forecast than the cross-sectional regression model alone or a time-series analysis alone, since it includes the structural explanation and non-structural explanation of the variance of the dependent variable.

The transfer function model has been utilized in some recent transit demand models (Kyte, Stoner \& Cryer, 1988; and American Public Transit Association, 1991). The advantage of the transfer function has been reported in both studies. Kyte, et al (1988) report that mean absolute percent errors of ridership forecast is less than 7 percent for most routes, indicating a very promising application in transit demand forecasting.

The transfer function model, as well as pooled time series model, needs large amount of longitudinal data in a systematical and consistent way. The large data requirements make it difficult to be applied at the transit route level. If yearly or quarterly data are used to estimate transfer function model, the socioeconomic and demographic data need to be available at the same time interval on the individual transit route. It may be possible to have yearly or quarterly transit ridership and transit service variable for individual routes, however, the socioeconomic and demographic data like population, income, employment are not available on the yearly or quarterly basis and at the scale of individual route level. Kyte, et al. (1988) use population and employment data at the county level to estimate ridership at the route level. This will cause inaccuracy in the model estimation, because many routes serve the same counties. Allocating population and employment data at the county level to individual routes has 
to make some strong assumptions and may not be reliable. Furthermore, the route alignment changes over time will cause problems in the estimation of the ARIMA part of the transfer function.

\section{Summary}

In summary, the route-level transit ridership model needs to estimate the likely response of ridership on a transit route to a change in the level of service and other land use changes. The changes are usually at the marginal level, it is thus inappropriate to use large regional transportation models like UTPS. The direct-demand regression model is more appropriate for the small-scale route-level service planning.

Within the direct demand model, cross-sectional models mainly deal with the spatial variations of transit demand and supply for a given point in time. They can include many transit service, land use, socioeconomic and demographic variables in the model. Cross-sectional models can be used to conduct detailed structural analysis and to determine the major determinant factors that affecting transit demand and supply. They are appropriate for policy analysis and short-run ridership forecasting at the route or route segment level. But they are not appropriate to address long-run structural shift and trend analysis.

Time-series models are used to deal with long-range temporal change. They are used to estimate transit demand changes over time. They are more appropriate for the system model than the route-level model. If the route configuration changed over time, these types of model may be deficient. 
The pooled cross-sectional and time-series model has the advantage of capturing both spatial variations and temporal variations of transit demand. But it is more suitable at the system level, it is difficult to apply in the route level because of large detailed data requirements.

The transfer function model adds the ARIMA part to explain the residual of the structural model and could have more accurate estimation of transit ridership. Similar to the pooled model, the transfer function is more appropriate for the system model. At the route level, it requires socioeconomic and demographic data on a short time interval (yearly or quarterly) at a small scale like a transit route or route segment level, which are usually not available and reliable.

The objective of this dissertation is to develop a model for short-run route-level service planning and policy analysis. This model needs to be sensitive to a marginal service and land use change. Furthermore, the population, income, and employment data are not available on the quarterly or yearly basis at the census tract level. There are some estimated numbers at some years, but the estimated methods used are not consistent over time and are not very reliable. Therefore, based on the evaluations of different models and the major objective of this study, as well as the limitations of the data, this dissertation applies a cross-sectional regression model to estimate short-run (less than five years) transit demand and supply, utilizing observed transit ridership and service variables in 1990 , as well as the 1990 census data as the major data sources. 


\section{PROBLEMS OF ROUTE-LEVEL TRANSIT PATRONAGE MODELS}

Although there are many models developed to estimate route-level transit demand, the reluctant use of these mathematical models by transit operators indicates that those models are not sufficiently reliable, accurate and easy to use for transit planners and schedulers. This also implies some problems and difficulties in the development process of route-level models. There are three major problems or difficulties in the route-level transit ridership estimations using cross-section models: lack of consistent data, ignorance of inter-route relationship, and lack of accounting for the simultaneity of demand and supply. This section will analyze these three problems.

\section{Problem 1. The Problem of Data Consistency}

For any regression model, a good quality data set is a key factor to an accurate model. The key question is whether the dependent variable and independent variables are measuring the subject from the same area at the same time. For example, if a regression model is to be developed to estimate the transit ridership as a function of population, ridership and population have to correspond, measured for the same region. If Portland's transit ridership in 1990 is regressed against the total population in the whole United States, or for Oregon, there is no way to have an "accurate" model.

For transit ridership model at the route level, the dependent variable is the boarding riders on a transit route or route segment. These boarding riders come from three sources: originating riders from local residential areas around the transit route, originating riders from park-and-ride users, and transfer riders from other transit route. 
Since there are three sources of boarding riders, the independent variables have to be the ones that can accurately describe the characteristics of those boarding riders. In other words, the dependent and independent variables have to be consistent.

Transfers from other routes need to be directly included as an independent variable in the model. For those riders who use the park-and-ride facilities, the parkand-ride lot capacity can be a proxy to be included in the model. The question remains as how to use variables that describe characteristics of originating riders who walk from and to local residential and employment areas.

Previous studies have shown that the walking distance is the most important determinant of transit usage (Lam \& Morrall, 1982; Horowitz and Metzger 1985). Most people will not walk more than a quarter mile, or approximately 5 minutes, to use the transit. Therefore, the transit service area is usually defined as a one-quarter mile distance around a transit line, or more precisely, around a transit stop.

This walking distance is crucial to potential transit riders. The walking distance affects the travelers' mode choices and even trip generation. Since most transit riders have both trip ends within the transit service area, it is reasonable to argue that only residents and employees in the walking distances of a transit route are likely to use the transit. The population and employment beyond the walking distance of a transit route can be considered as irrelevant to the ridership for that route. Including those social and demographic characteristics beyond walking distance of a transit route as independent variables in the model will introduce error.

Some previous studies have used this service area concept in transit demand 
modeling (Yuratovac, 1982; and Hunt, et al, 1986). But many other analyses lack this consistency. For example, Kyte et al (1988) relied on county level population and employment to estimate their route level models. If two routes run through the same counties, the same population and employment will be used to estimate the ridership on both routes.

Some other studies use population and employment at the census tract level to estimate route-level ridership. A census tract could be as large as several square miles, a transit line may only serve a very small partial of this census tract. Using the total population to estimate ridership will inevitably cause errors. For a route level transit ridership estimation model, in which the population and employment are major determinants of transit demand, this lack of consistency among variables is the major source of inaccuracy in estimating route level demand models (Multisystems, Inc., 1982).

\section{Problem 2. Inter-Route Relationship}

Inter-route relationship is an important factor in estimating transit ridership at the route level. Most previous models are single-equation models and treating transit route as independent from each other. One shortcoming of a single-equation regression model is that it lacks a systematic view of the whole transit system, and ignores the service and ridership impacts on its related routes. A transit system is an interrelated network rather than a set of independent routes. A change of service and ridership on one route may have impacts on its related routes. 
A single equation model assumes that the transit ridership on a particular route is determined primarily by the level of service offered by that route, the socioeconomic and demographic characteristics on the service areas of that route. And this route has no relationship with other transit routes. In other words, changing other parts of the transit network would not significantly affect the transit ridership on this route.

Such assumptions are certainly invalid. Riders select routes and passengers transfer. Many transit network systems are designed to facilitate transfer of riders between routes, such as Tri-Met's timed-transfer system in suburbs and the grid system in the urban areas. The availability of transferring not only affects the ridership on the route to which the passengers transfer, but also affects the patronage on the subject routes. People may choose not to use the bus or even forego the trip if there is no straight service nor transfer routes.

Some routes use the same road or closely parallel roads, and compete with each other for passengers. People living in those areas have a choice among routes. Those residents are double counted in more than one route's ridership determining factors in the single equation model. Single equation models over-estimate the potential ridership for routes that share the same service areas.

The issue of inter-route relationships has been ignored in most previous studies of route-level transit ridership estimate models. A study by Alperovich, Kemp and Goodman (1977) is an exception, in which inter-route transfers have been specifically discussed. The transfer passengers on the subject road from other routes are modeled as a function of the total ridership on this route, the number of interconnecting transfer 
routes, and a set of route type dummy variables. It is interesting to note that the transfer passengers are modeled as a function of the total ridership on the subject route, not the total ridership on those routes with which the subject route intersects. The authors experience some difficulties in using a sample of routes in the analysis. By using a sample rather than a whole population of the routes, the necessary patronage volumes cannot all be generated endogenously within the model. Using total ridership on the subject routes to estimate the transfer passenger volume is an unfortunate proxy. In addition, their model does not discuss another important inter-route relationship, the competing relationship, i.e, a service and ridership change on one route may have possible impacts on other parallel routes.

\section{Problem 3. Simultaneity between Transit Demand and Supply}

The ridership on a transit system is the result of two decision-making processes: that of the riders and that of the transit planners or schedulers. The riders' decision making process determines the demand for transit services, while the planners' or schedulers' decision-making process determines the supply of transit services. These two decision-making processes constitute a simultaneous demand and supply system. Transit riders respond to service changes, while the transit planners adjust transit services based on their expectation of future ridership and other factors.

It has been well understood and modeled in the previous studies that transit demand is a function of transit services. Many single regression equation models are based on this understanding. This single-equation model does not reflect the transit 
planners' or schedulers' decision process, that is, that the transit service provided on a route is determined by the previous ridership and the planners' expectation of future ridership on this route, as well as the availability of fare box revenues and subsidies.

The traditional single-equation model represents only one decision-making process, that of the transit users' response to changes of level of service. It does not reflect the decision-making rule of transit planners. A single-equation model cannot reflect this multiple decision-making process and the feedback relationship.

The single-equation model assumes causality in one direction; the level of transit service determines transit ridership. This one directional causality assumes that the transit planner can randomly put bus service on the road, the riders will respond to it. It ignores the important decision making process in the service supply side. Therefore, the single-equation model is static and deterministic in nature. It cannot reflect the dynamic process of the whole system.

A single regression model regressing ridership on transit services generates estimates that could be estimates of the demand parameter, the supply parameter, or, some combination of these sets of parameters. In a model using transit service level as an independent variable, a simple ordinary least square (OLS) regression will result in a coefficient estimate of the transit service variable. That estimated coefficient is a combined effect of transit demand response to service changes and transit planners' response to ridership changes. If we consider that the coefficient of service variable is the only contribution of service changes to ridership changes, the demand response to transit service changes would often be over-estimated or under-estimated. Such models 
often prove to be overly sensitive to frequency of service (Multisystems, Inc., 1982). Gaudry (1975) developed a simultaneous equation model for the bus demand function and supply function, using systemwide aggregate data from the Montreal Urban Community Transit Commission system. He states that on the demand side, transit ridership is a function of present transit service and other exogenous variables. On the supply side, the transit service is a function of ridership at the previous year, and other exogenous variables with a lagged time period. He argues that absolute supply levels are in general fixed once a year at the budget time, the service quantity supplied during any time period depends primarily on past (rather than current) levels of demand, expected costs, and some other factors.

Gaudry's model is actually a recursive model. The supply and demand functions can be regarded as shifting independently, or nearly so. And the supply and demand equation can be solved independently using OLS. There is no feedback effects from the demand equation to the supply equation, because the service supply depends on the previous year's ridership, not the current ridership.

Alperovich, et al (1977) have calibrated a set of simultaneous equations to estimate the supply and demand of transit services of individual routes. The authors assume the transit supply and demand are fully simultaneous. Three equations of the supply function and two equations of the demand function are designed to address the simultaneity of demand and supply.

But their simultaneous model totally ignores the route specific demographic and socioeconomic information in its supply and demand equations. Although the five 
equation model looks promising, a better model specification is needed because of the lack of socioeconomic and demographic variables and the complexity of the model, (Multisystems, Inc. 1982).

In summary, data consistency, inter-route relationship and simultaneity of supply and demand are three major problems, among many others, in route-level transit patronage estimate models. This dissertation intends to specifically deal with these problems while it develops a route-level transit patronage model. A GIS is used to allocate demographic and socioeconomic data to the service areas of specific routes, and to analyze inter-route relationship. The simultaneous-equations model is applied to address interrelationship among transit routes and to simulate the interactive process of transit demand and supply. 


\section{CHAPTER 3}

\section{A GIS DATABASE DESIGN AND SPATIAL DATA ALLOCATION}

\section{INTRODUCTION}

Transit demand modeling is data driven. Valid and accurate data are needed for model specification, a key factor to generate an unbiased estimation of a transit demand model. Invalid data or inaccurate data will result in biased and inefficient model estimation. Transit ridership, transit service, socioeconomic and demographic data are not generally stored in consistent geographic units that are required for transit demand modeling. Therefore, GIS database design is needed to integrate data to common spatial units.

Several efforts to address the issue of common digital map databases for a variety of applications for public transportation systems are underway. The Advanced Public Transportation (APTS) Map and Spatial Database User Requirements Working Group (MSDWG) is addressing the issue of standardization of spatial data entities for transit service (Okunieff, 1994). The MSDWG efforts focus on a broad range of potential applications, such as demand-responsive systems, fixed route operations and service planning, customer information systems, and transit decision support systems. A common database requirement provides a basis of defining and describing transit data elements in a consistent and transferable form, so users can integrate different data with 
a common definitions and common relationships among data sets.

This chapter discusses the data requirements for transit demand modeling from the standpoint of GIS database design. It addresses the issue of data requirements, data structure and data integration for transit demand modeling. Two data integration issues are addressed: the spatial and attribute data allocation, and the inter-route relationship. The accuracy of different methods to allocate demographic and socioeconomic data from census areas to the service areas for transit routes are compared, using data from Tri-Met service area. Spatial data integration is also used to analyze transit inter-route relationships. Inter-route relationship analysis is needed in route-level ridership models to estimate the ridership impacts of service changes not only on the route with the service changes, but also on other related routes.

\section{DATABASE REQUIREMENTS OF TRANSIT DEMAND MODELING}

Different data are required for three major categories in the direct demand modeling: cross-sectional, time-series, and the combination of the two. But they all require spatial data and temporal data.

Cross-sectional models mainly deal with the spatial data. They relate observed transit uses, transit service and socioeconomic variables over space for a given point in time. Time is not considered explicitly and independently in the modeling process. Different models are developed for different time periods, such as models for the morning peak, midday, afternoon peak, evening and night period. Modeling variations

over different time period of a day requires spatial data for the corresponding time 
period of a day.

Time-series models mainly deal with temporal data. They are developed to estimate transit demand changes on a spatial unit, usually for the whole metropolitan region, as service and other variables change over time. To treat spatial variations individual models are developed for each spatial unit or different bus routes. Timeseries models primarily require longitudinal data. If the route configuration changed over time, however, a spatial database is also needed over time.

A combination model of cross-sectional model and time-series model is used to capture variations of transit ridership in time as well as in space. Therefore, it requires both spatial and longitudinal data at the same time.

In addition, there are also ridership and service variations by direction. For example, in the morning peak period, there is a large difference of ridership between inbound and outbound direction. To serve the purpose of route-level service planning, the database design must address these spatial, temporal and directional variations to satisfy the needs of transit demand modeling.

Typically direct demand models are regression models. Transit ridership is modeled as a function of a set of independent variables: transit services, socioeconomic and demographic data in the service areas. So at least three kinds of data: ridership, transit services, and socioeconomic and demographic data are required for any transit demand modeling process. 


\section{Ridership Data}

For transit ridership models, the dependent variable is usually the boarding rides on a spatial unit such as a stop, a route segment or a transit route. These boarding rides come from three major sources: originating rides from local residential areas around the transit stop, originating rides from park-and-ride users, and transfer rides from other transit routes. A database should include these three sources of transit rides and relate them to a specific geographic location, for time periods where appropriate.

\section{Service Data}

Transit service includes service quantity variables such as bus frequency, hours of service, and route length of service; and quality variables such as on time performance. Transit service variables also include the location, usage and capacity of park-and-ride lot provided by transit agencies.

\section{Socioeconomic and Demographic Data}

Transit riders take transit from origins to destinations. It is the characteristics of those origins and destinations that determine the demand for the transit service. Demographic and socioeconomic characteristics at the place of residence are the ridership production factors, which describe the potential transit users at trip origins. These include population and age structure, household income, auto ownership, and so on. The demographic and socioeconomic characteristics at the destination are the ridership attraction factor, representing the potential destination of the transit trips. This 
includes such data as employment and high school enrollment.

These data may be related to different spatial units. Some are related to transit stops like boarding and alighting rides, some are related to transit routes such as service frequency, and some are related with statistical areas such as population and employment. A regression model requires these variables to be measured in the same geographic unit. In other words, all variables have to be consistent in space and in time. To achieve this data consistency, these data sets have to be spatially related and integrated.

\section{SPATIAL AND TEMPORAL TRANSIT DATABASE DESIGN}

To relate these data spatially, each variable has to be related to a common geographic unit. A geographic unit can be represented by an abstract spatial feature: point, link, segment, route, and polygon.

A point is a basic unit of location. It can be represented by an $(x, y)$ coordinate, or a milepoint. It has zero dimension. From the modeling point of view, the transit stop, the starting and ending point of a transit route, an intersection point of two transit line, a transit transfer center, and the centroid of a high school or a park-and-ride lot can be treated as spatial points.

A link is a line between two points. It has one dimension. The line between two bus stops is a spatial link. A line between a bus stop and a rider's home is another example of a link.

A segment is one or more continuous links. The piece of a transit route within 
a fare zone is a segment of the route.

A route is a set of links beginning from a starting point (from-node) to the ending point (to-node) of a transit line.

A polygon is an enclosed area bounded by three or more links, such as a census block, block group, census tract, fare zone or transit service area of transit stops or routes.

Every spatial feature has associated attribute data. For example, a bus stop is associated with the number of boardings, alightings and transfers. A fare zone segment of a route has associated characteristics such as transit fare structure. A transit route is associated with route typology such as a radial, crosstown, feeder or express route. A polygon has associated small area data, such as employment and population. A detail list of spatial features and their attribute data is shown in Table 3.1.

The relationships among the spatial features can be established by either dynamic segmentation or relating them back to the enhanced Topologically Integrated Geographic Encoding and Reference (TIGER) line file, developed by the U.S. Census Bureau, by retaining TIGER arc and node identifiers.

Transit stop point data and linear data can be easily related by using dynamic segmentation, because they are related by the common route. The bus stops and the breaking points of the segments of a transit route are linked by mileposts and route identifiers.

The relationship among bus stops on one route and those in other transit routes can be related by unique bus stop identifiers or by reference to common TIGER lines 
and nodes. The potential transfer points can be identified by analyzing the point relationships. Bus stops are unique, but one bus stop can relate to many routes. Relating point and linear transit data to the TIGER network enables integration of point, linear and polygon data. For example, the continuity relation can be used to search for the blocks (polygon data) that are within a quarter mile walking distance from a bus stop (point data). More detail about the spatial data allocation is included in the next section.

TABLE 3.1 Attribute Data and Their Associated Spatial Features

\begin{tabular}{|c|c|c|c|c|c|}
\hline $\begin{array}{c}\text { Abstract } \\
\text { Spatial } \\
\text { Data }\end{array}$ & Point & Link & Segment & Route & Polygon \\
\hline $\begin{array}{l}\text { Spatial } \\
\text { Features }\end{array}$ & $\begin{array}{l}\text { Transit stop, } \\
\text { starting and } \\
\text { ending point, } \\
\text { intersection, } \\
\text { transfer center, } \\
\text { centroids of } \\
\text { park-and-ride } \\
\text { lot, high } \\
\text { school... }\end{array}$ & $\begin{array}{l}\text { piece of } \\
\text { transit } \\
\text { route... }\end{array}$ & $\begin{array}{l}\text { part of a } \\
\text { transit } \\
\text { route } \\
\text { segmented } \\
\text { by fare } \\
\text { zone ... }\end{array}$ & $\begin{array}{l}\text { an entire } \\
\text { transit } \\
\text { route... }\end{array}$ & $\begin{array}{l}\text { census } \\
\text { tract, } \\
\text { block } \\
\text { group, } \\
\text { block, fare } \\
\text { zone, } \\
\text { service } \\
\text { area... }\end{array}$ \\
\hline $\begin{array}{l}\text { Attribute } \\
\text { Data }\end{array}$ & $\begin{array}{l}\text { Boarders, } \\
\text { alightings, } \\
\text { transfers, } \\
\text { on time } \\
\text { performance, } \\
\text { park-and-ride } \\
\text { lot capacity, } \\
\text { high school } \\
\text { students... }\end{array}$ & $\begin{array}{l}\text { Travel } \\
\text { distance, } \\
\text { travel } \\
\text { time, } \\
\text { bus } \\
\text { speed ... }\end{array}$ & $\begin{array}{l}\text { Travel } \\
\text { distance, } \\
\text { travel } \\
\text { time, } \\
\text { bus speed, } \\
\text { transit fare } \\
\ldots\end{array}$ & $\begin{array}{l}\text { service } \\
\text { length, } \\
\text { hours of } \\
\text { service, } \\
\text { service } \\
\text { frequency, } \\
\text { total seats } \\
\text { in a bus... }\end{array}$ & $\begin{array}{l}\text { employ- } \\
\text { ment, } \\
\text { population, } \\
\text { age } \\
\text { structure, } \\
\text { car } \\
\text { ownership, } \\
\text { income... }\end{array}$ \\
\hline
\end{tabular}


There can also be a temporal component at every spatial unit. For each bus stop, for instance, there could be ridership data by the time of a day, by season, or by year. The temporal component can be for a time point, time period and time range. The time point is the basic unit of time like $2: 00 \mathrm{pm}$. A time point data are not necessary in most modeling applications, unless used in a real-time application. Time period is a subdivision of a day, a time unit within one day, or a week, such as the morning period, morning peak period, or the weekend. Time range is a longer period of time, such as a season or a year.

In addition, there is also a directional component. The directional component can be treated in three ways. The first method is a symmetric system, i.e., the data are the same for both directions in a linear system. For example, if two bus stops for inbound and outbound are on the two way street, and are oppositely located cross the road, these two bus stops can be considered as one in a linear network system like a street centerline file. Ridership data in either direction can be related by the same bus stop but with different directions.

The second method is for a nonsymmetric system, i.e., data points for two directions are not the same. The directional data are related to different geographic locations. For example, in an one way street, the bus stop for inbound and outbound direction will have different locations, and must be treated as independent points.

The third method is to apply a dynamic segmentation to both directions of the route. So for the same stop point, the milepost for the inbound direction is different for the outbound direction. Bus stops may have additional relations, such as address, $(x, y)$ 
coordinate, or TIGER line identifiers to enable relating to data with those geographic units.

\section{DATA INTEGRATION}

For the purpose of transit demand modeling, data have to relate to the same geographic unit. In other words, the model must be either at the bus stop level, a bus segment level, or the bus route level. If the unit of observation is at the bus stop level, all the linear data and polygon data must be converted into the point data that are associated with the individual bus stops. That is, at each bus stop, there must be a data set that describes the transit ridership, transit service, and population and employment within walking distance of that stop. Similarly, if the basic observation is at the bus route segment or a route level, the point and polygon data have to be converted into the route segment or route level.

It is not a problem to convert the point data to the linear data or vice versa if the points are located on the same route (line) or in the route service area (polygon). In fact, the advantage of the dynamic segmentation is its ability to store and transfer point and linear data interchangeably (Dueker and Vrana, 1992). It is more difficult, however, to convert polygon data, a two-dimensional database to point or linear data system.

The overlay operation in GIS is often used to integrate polygon data and point or linear data. Caution must be exercised to determine whether the topological and geometric relations represent the real relationship among the polygon, point and linear 
data. In other words, even though the population in a census tract can be associated with a bus stop or a route segment by an overlay and allocation operation in GIS, it is yet to be determined whether that population contributes to the transit ridership in that transit stop, or whether the transit service in that segment serves all or part of the population in that census tract. The question remains as to specifying or allocating population and the kind of population to transit routes.

To allocate polygon and point data to transit routes, the transit service area has to be defined. Previous studies have shown that walking distance is the most important determinant of the transit service area (Lam \& Morrall, 1982; and Horowitz and Metzger 1985). The transit service area is usually defined as a one-quarter mile around the transit lines, or more precisely, around transit stops.

The service area for each transit route can be delineated by either a geometric distance buffer or a topological neighborhood search (Dueker and Vrana, 1991). For a geographic buffering approach, bus stops are buffered by a quarter mile distance, because it is the bus stops that determine the real walking distance. The area inside the buffer is the service area for that particular transit stop. Because the distance between bus stops is usually less than a quarter mile, there will be considerable overlap among bus stop buffers. Objects such as population in those overlapped areas are allocated to the nearest bus stop. This is a useful approach if the transit demand model is developed at the bus stop level.

If the model is developed at the route segment or route level, however, buffering bus stops and allocating objects to bus stops is not necessary. Bus routes, 
rather than bus stops can be buffered for urban routes wherein the bus stops are less than a quarter mile apart. This can achieve sufficient accuracy and reduce the redundancy of buffering individual bus stops on bus routes.

The topological approach delineates the service areas of a transit stop by searching for a quarter mile distance in the street network. This approach considers the actual walk distance in the street network, so it is more accurate to define a transit service area. However, in the urban areas where the network is very dense, the geometric and topological approaches produce similar results, but the geometric approach is much more simple and efficient.

In developing a transit demand model at the route segment level, this dissertation uses the geometric buffering approach. A quarter mile distance is used to buffer a bus route segment and a light rail station to define the transit service areas. Because the light rail stations, unlike most bus stops, are usually more than half a mile apart, the demographic and socioeconomic data are then allocated to buffers around station points. The demographic and socioeconomic data are mainly from the 1990 U.S. census, available at the geographic unit of census tract, block groups and census block. Since the boundaries of these geographic units are not consistent with the boundaries of the transit service area buffers (Figure 3.1), data in those different geographic units (census tracts, block groups and blocks) have to be allocated to the route service areas.

Count and attribute data are allocated differently. Count data, including the number of population, employment, high school enrollment, and park-and-ride facilities, are counts of spatially distributed subjects and can be allocated to different geographic 


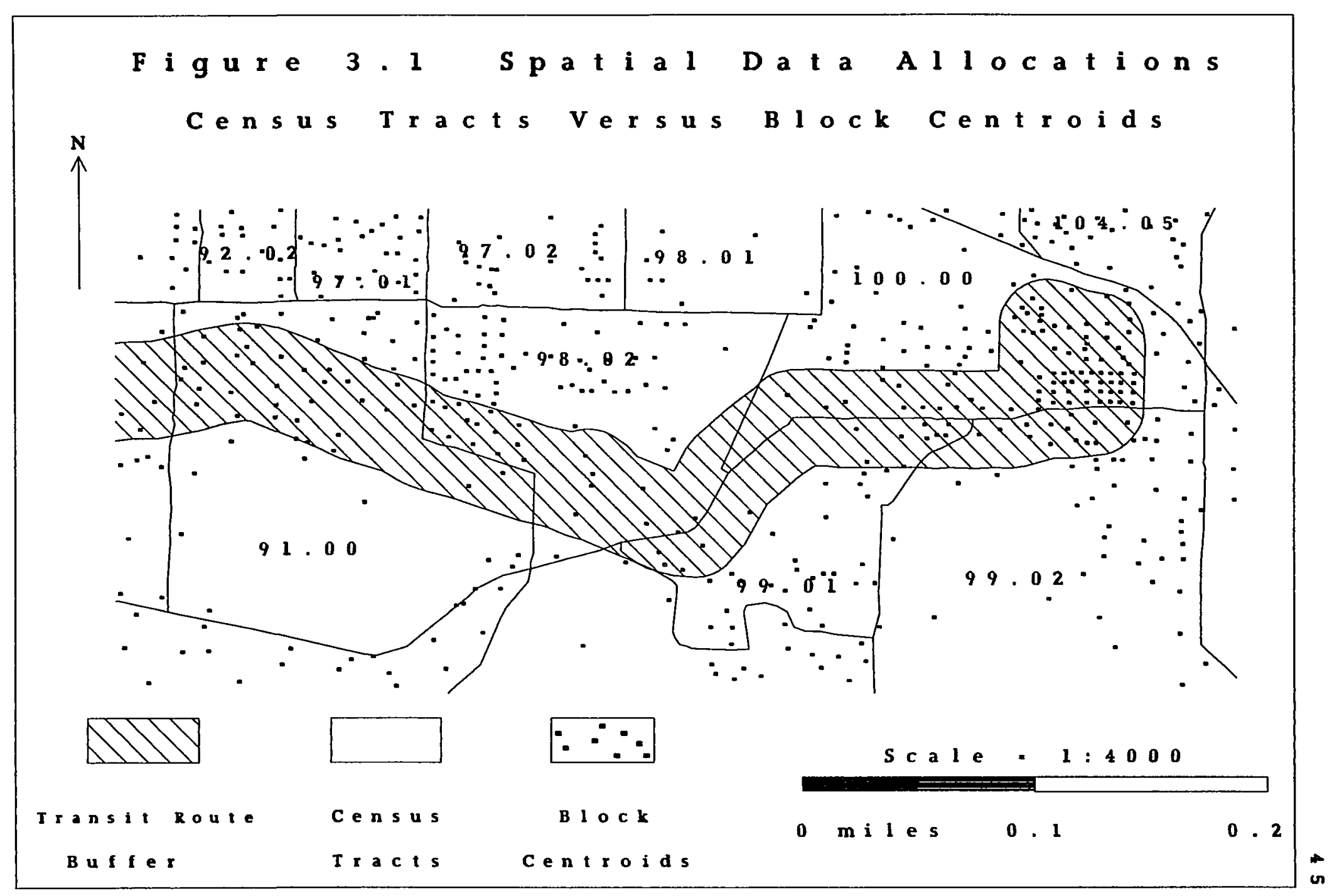


units by overlay functions in GIS, i.e., spatial allocation. Attribute data representing the characteristics of those count data, like income, auto-ownership rate, population age structure cannot be allocated by the overlay functions in GIS, unless these data are at the individual person or household level. They have to be allocated differently as discussed later.

\section{Count Data Allocation}

Count data in an areal unit are the aggregate number of objects or features. There are four basic methods of count data allocation (Peng \& Dueker, 1993). They are: all or nothing allocation, allocation based on the uniform density assumption, allocation based on land use types and allocation based on block centroids. These four allocation methods are by no means exhaustive, they are the most commonly used in spatial data allocation.

All-or-nothing allocation allocates spatial count data like population and employment of whole census tracts or block groups to the bus route service area if the transit line buffer coincides in part or whole with the census tract or block group. The whole census tract or block group is considered as being served by the bus route as long as there is some common area between a bus route buffer and the census tract or block group, regardless of how large or how small the common area. If a census tract or block

group is very large and a transit route runs on a major arterial, which is often the boundary of census tracts, the real walking distance for some people living in the census tract may be far more than a quarter mile (see Figure 3.1). Assuming they all are served 
by the transit route is unreasonable. Including them in the route-level transit patronage estimation model as determinants of transit ridership introduces measurement error.

The uniform density allocation assumes that the population and employment in a census tract are uniformly distributed, and the allocation of population and employment is based solely on the proportion of the area of a census tract that is within the bus line buffer area. This method will result in errors in tracts where population is not uniformly distributed. It is especially inappropriate for employment data, because employment is often clustered together rather than evenly distributed.

Allocation based on the type of land use relates population to residential land uses and relates employment to non-residential land use. Population and employment can be allocated uniformly to residential land acres and non-residential land acres, respectively, or allocated based on floor area. This is a better alternative than the uniform density allocation method. Still it can introduce errors if population and employment are concentrated and mixed, such as a mix of single family and multifamily housing, and a mix of different commercial and industrial land uses.

Allocation based on census block centroids assumes all the population in the census block is located at a single point (block centroid). The whole block's population is allocated to the transit service area if the block centroid is located inside the transit route buffer area.

In urban areas, a census block is the most detailed geographic unit for which census data are available, and it is small enough to be considered as a spatial point. This dissertation uses 1990 census block data to allocate population to the transit route 
service areas. The point coverage of census block centroid was first overlaid with the transit route or stop buffers, the route-specific population within the service areas were aggregated by summing population of block centroids inside the buffer.

To compare the accuracy of different data allocation methods, the uniform density and the all-or-nothing allocation methods are used to allocate population to transit route buffer, using census data in Portland, Oregon metropolitan area. The allocated results were compared to that using the census block centroid. The difference of these three methods is shown in Table 3.2 , and assumes the population allocated by the block centroid is the ground truth and the basis of comparison.

TABLE 3.2 Comparisons of Population Allocation Results Using Different Methods at the Transit Route Segment Level

\begin{tabular}{|l|l|l|l|l|}
\hline & UDBG & AONBG & UDCT & AONCT \\
\hline Median difference & $7.4 \%$ & $202.0 \%$ & $13.0 \%$ & $327.9 \%$ \\
\hline Mean difference & $44.6 \%$ & $1057.9 \%$ & $35.6 \%$ & $2762.4 \%$ \\
\hline
\end{tabular}

The results shown in Table 3.2 are difference of three methods of population allocation to the bus route buffer aggregated at the route segment level. There are four segments segmented by fare zones in Tri-Met service area, zone $0,1,2$ and 3, concentric with the downtown Portland central business district (CBD). The numbers in the tables are the percentage differences of allocated population as compared with that of block centroid method (BLOCK). These differences are for the all-or-nothing (AON) and uniform density (UD) allocation methods at both the block group (BG) and 
census tract (CT) level, respectively. These differences are calculated by the following formulas:

$$
\begin{aligned}
& \underset{\text { Average Percentage }}{\text { Difference of } \mathrm{AON}_{\mathrm{z}}}=\frac{\sum_{\mathrm{z}}\left|\sum_{\mathrm{j}} \mathrm{AON}_{\mathrm{jz}}-\mathrm{BLOCK}_{\mathrm{z}}\right|}{\sum_{\mathrm{z}} \mathrm{BLOCK}_{\mathrm{z}}} * 100 \\
& \begin{array}{c}
\text { Average Percentage } \\
\text { Difference of } \mathrm{UD}_{\mathrm{z}}
\end{array}=\frac{\sum_{\mathrm{z}}\left|\sum_{\mathrm{j}} \mathrm{UD}_{\mathrm{jz}}-\mathrm{BLOCK}_{\mathrm{z}}\right|}{\sum_{\mathrm{z}} \mathrm{BLOCK}_{\mathrm{z}}} * 100
\end{aligned}
$$

Where $\mathrm{j}$ is the geographic area on which the population allocation is based. $\mathrm{j}$ could be either the census tract (CT) or the block group (BG) number. $z$ indicates the allocated population are compared at the route segment (fare zone) level. BLOCK is the allocated population at the fare zone $\mathrm{z}$ based on the population in the block centroid.

It can be seen from Table 3.2 that the uniform density method is better than the all-or-nothing allocation, and the block centroid method is much better than the uniform density allocation. In terms of allocation errors of the area type, blocks produce the least error, followed by block group, and then census tract. Note there is a big difference between the mean and the median, because the mean error includes larger outliers.

It should be noted that the differences in Table 3.2 are aggregated at the route segment level. Aggregation tends to reduce the variance and errors. They are balanced in aggregation. If the allocation difference of different methods is compared at the census tract level, the difference is much larger. Peng and Dueker (1993) have a more detailed analysis that shows the allocation to a whole route buffer introduce less error 
than does allocation to a smaller geographic unit like a census tract. It is interesting to note that the mean difference of uniform density allocation using census tracts is less than that using block groups at the route segment level. This may be due to the balance of the over-allocation (positive difference) and under-allocation (negative difference) in the process of aggregation, it does not necessarily indicate the population allocation based on the proportion of census tract areas is better than that based on the block group areas.

Unlike population data, employment data are simply not available at the census block level. The same allocation method used for population allocation cannot be used to allocate employment data.

Employment data are only available at the census tract level by industry in Portland metropolitan area. METRO, the regional planning organization at Portland metropolitan area, geocodes state employment data to census tracts. This dissertation has allocated these employment data to route-specific service areas based on land use types, from METRO's parcel level Regional Land Information System (RLIS). RLIS is used because it identifies land use type at the individual parcel level. Every land parcel in the RLIS data base has a specific land use type, i.e., residential single family, residential multifamily, industrial, commercial land uses and farm lands.

In the employment data set, there are five categories of employment by industry: manufacturing, commercial, government, transportation and real estate, and agricultural. These industrial categories are not consistent with the land use categories. In order to allocate employment data to land use, this study relates manufacturing 
employment to industrial land use, agricultural employment to farm lands, and all other employment to commercial land uses. The employment allocation process is described as follows.

First of all, each land parcel in the RLIS was converted to a centroid point. Then RLIS parcel point coverage are overlaid with the census tract polygon coverage. Parcel-level floor area and land use area by different land use types allocated to census tracts were aggregated, and employment density (employment per unit of floor areas or land use areas) by employment type was calculate using Equation (3.3). For example, if census tract $i$ has 500 manufacturing employees and 250 acres of industrial land, its manufacturing employment density is 2 employees per acre.

$$
\text { EMPLOYMENT DENSITY }_{p k}=\frac{\text { EMPLOYMENT }_{p k}}{\text { LAND OR FLOOR AREA }_{p k}}
$$

Where the subscript $\mathrm{p}$ is employment typology: commercial, industrial, and agricultural, and $\mathrm{k}$ is the census tract number.

For commercial employment allocation, floor area rather than the land area is a better measurement of employment density. However, the floor area data are only available from Multnomah County in the Portland metropolitan area, the same variable has too much missing data in Clackamas and Washington counties. They could not be used with confidence. Therefore, floor areas in Multnomah County and land areas in Clackamas and Washington counties are used to calculate commercial employment density for census tracts.

Next, the transit buffer was intersected with the commercial land use point 
coverage from RLIS and the census tract polygon coverage. If the centroid of a land parcel is located inside the buffer, that parcel is counted as being served by the transit route. Land areas and floor areas inside the route buffer in each census tract by land use types were aggregate and used to calculate the proportion of these land and floor areas that are within the buffer by land use typology.

Lastly, the specific employment in transit buffer areas is the product of the employment density of an employment type and the proportion of the land area or floor area inside the buffer as illustrated by Equation (3.4). The employment in a census tract served by the transit is the summation of employment of all employment types in the census tract (see Equation (3.5)). The total employment served by a whole transit route is the summation of employment served in all census tracts the transit line buffer goes through (see Equation (3.6)).

$$
\text { EMPLOYMENT }_{\text {ipk }}=\text { EMPLOYMENT DENSITY }_{\mathrm{pk}} * \frac{\text { LAND OR FLOOR AREA }_{\text {ipk }}}{\text { LAND OR FLOOR AREA }_{\mathrm{pk}}}
$$

$$
\text { EMPLOYMENT }_{\text {ik }}=\sum_{\mathrm{p}} \text { EMPLOYMENT }_{\mathrm{ipk}}
$$

$$
\text { EMPLOYMENT }_{i}=\sum_{\mathrm{k}} \text { EMPLOYMENT }_{\mathrm{ik}}
$$

Where the subscript $i$ is the route buffer area of the transit route $i$, and the subscript $\mathrm{p}$ and $\mathrm{k}$ are defined as in Equation (3.3).

The allocation of high school enrollment and park-and-ride facilities are relatively simple. The location of high school and park-and-ride lot is represented by a point coverage. High school enrollment number for every high school that does not 
have school bus system are from the school districts in the Portland metropolitan area. High school enrollments represent major transit usage attractions because the Portland School District, unlike suburban cities, does not provide school bus service for high school students. Every high school is allocated to a specific bus route using the overlay operation in GIS. The point coverage of high school location is intersected with the transit route buffers. High schools are allocated to the buffer when they are within the bus service areas. One high school may be allocated to more than one bus line if there are more than one bus line are within walking distance of the school, indicating there are more than one bus service available for that school.

Park-and-ride lot location is also a point coverage. Each park-and-ride lot is represented by a spatial point. Its allocation to transit service areas is simply an overlay operation, the same as the high school enrollment allocation. Park-and-ride lots are provided by Tri-Met to facilitate transit riders beyond walking distance. Ideally, the park-and-ride lot usage rather than capacity should represent the real demand for transit use, because some park-and-ride lots are heavily used while others are poorly used. However, the park-and-ride lot usage data are not available, and capacity serves as a proxy to the real demand for transit uses.

It should be noted, however, there are limitations in these spatial data allocation procedures. First, although blocks are small enough to be considered spatial points, they may be large in suburban and rural areas. Where blocks are large, they should be treated as polygons rather than as points.

The second limitation lies on allocating employment according to land area. 
Using land area to allocate commercial employment is crude. The uniform density assumption within the same land use type is also questionable, because for different commercial land uses, employment density varies. Employment density of a car lot may not be the same as that of a retail store.

The third limitation is the errors associated with GIS operations, especially for spatial overlays (Blakemore, 1984; Flowerdew, 1991; and Pullar \& Beard, 1990). The commonly mentioned problem in spatial overlay operation is the creation of a host of "sliver polygons" and "dangling chains" (Flowerdew, 1991), and the mismatch of a point on a polygon or line. Since the census tract coverage and the RLIS come from different sources errors can occur in overlaying. Error arises when the land parcel is out of the census tract when it should be in, and vice versa.

\section{Attribute Data Allocation}

Different people have different taste and demand for transit service. These differences between people are usually characterized by categories of age, income, car ownership and other attribute variables that describe the characteristics of persons and households. These characteristics are very important factors that determine transit ridership.

At the individual level, every person has associated characteristics, there is no need for allocation. At the aggregate level data allocation is necessary if attribute data are only available at the higher level of aggregation. Such is the case of population count data that are available at the block level, while detailed attribute data like income 
and car ownership are only available at either the block group or the tract level. The attribute data have to be allocated.

Since this study used population of 1990 at the block level to allocate population to the bus route buffer, income and auto ownership data at the block group level have to be allocated to the buffer areas. Three methods can be used to allocate such attribute data as income and car ownership.

The first method is to assume each block is like its parent block group. For example, the proportion of zero auto ownership households of a block group is used to calculate the zero auto ownership households that are within a transit route buffer for the same block group. That is, to estimate the number of household without automobiles for the part of the block group $\mathrm{g}$ that is inside the route $\mathrm{i}$ buffer area, the formula (3.7) can be used:

$$
\text { Zero auto households }_{\text {ig }}=\frac{\text { Zero auto households }_{\mathrm{g}}}{\text { Total households }_{\mathrm{g}}} * \text { Households }_{\mathrm{ig}}
$$

The second method is simply to apply the median income of a block group to all blocks of that block group, as is illustrated in Equation (3.8). This method cannot be used to allocate auto ownership data, unless the average auto ownership is calculated for the block groups.

$$
\text { Median } \text { income }_{\mathrm{b}}=\text { Median } \text { income }_{\mathrm{bg}}
$$

Where b represents block, and bg represents block group.

These two methods are based on an assumption that the population and 
households are homogeneous inside a block group. This is a strong assumption, because inside a block group there can be considerably spatial variations. This limitation is reduced by aggregation of the individual allocations to the route segment buffer.

The third method is to use a regression model to estimate population attributes. Even though the census data does not provide income data at the block level, it does, however, provide block level surrogates of income such as housing values, rents, age structure and housing size. If a relationship can be found between income and these surrogates at the block group level, the income of the households at a census block can be derived.

Lycan (1993) formed a relationship of income and its related variables using a regression model at the block group level. The estimated coefficients can be applied to the variables at the block level. Equation (3.9) illustrates the regression equation at the block level. The linear model is estimated using ordinary least squares to obtain coefficients of those independent variables.

$$
\text { INCOME }_{g}=\alpha+\beta_{1} \text { HOUSVAL }_{8}+\beta_{2} \text { RENT }_{8}+\beta_{3}{\text { PCT } 65 O_{8}}_{8}+\beta_{4} \text { PCT18U }_{8}+\beta_{5} \text { SIZE }_{8}+\beta_{6} \text { PER/ROOM }_{8}+\epsilon
$$

Where, the subscript $g$ means all variables are at the block group level, INCOME is the median income; HOUSVAL and RENT are the median housing value and rents; PCT65O and PCT18U are percentage of population with age of 65 years old and over, and with age of 18 and under, respectively; SIZE is the housing size measured by square footage, and PER/ROOM is the average persons per room; $\epsilon$ is an error term. These estimated coefficients $\left(\hat{\alpha}, \hat{\beta}_{1}, \hat{\beta}_{2}, \hat{\beta}_{3}, \hat{\beta}_{4}, \hat{\beta}_{5}, \hat{\beta}_{6}\right)$ are then applied to the 
independent block data. At the block level, these estimated coefficients and its corresponding variables are used to estimate income for each individual block as shown in Equation (3.10).

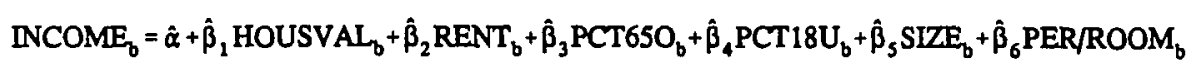

Where the subscript $b$ indicates all variables are at the block level.

One problem of this approach is that there are many missing data for some variables at the block level such as housing values and rents. Income cannot be estimated if any of the variables is missed from the block, especially the important variables of housing value and rents.

This means additional models are needed at the block group level with the selected variable(s) excluded. Then, estimates can be made for blocks with missing value for rent, if there are no rental housing units in that block. This block group level model should exclude the rent variable, using those block groups that are mostly owner occupied (such as 90 percent) to estimate the coefficients. Similarly, another model at the block group level could exclude the housing value variable, using those block groups that mostly renter occupied to estimate coefficients to apply to blocks having no owner occupied housing units.

There are several problems associated with these alternative models. The first problem is that there may not be enough block groups without housing value to estimate a model, because not many block groups are purely renter occupied. The second problem is that if the model excludes the housing value variable, and some 
block groups have owner occupied housing, the model will not be fully specified. An incorrect specified model will result in a biased estimation. The third problem is that if all variables are expressed in terms of median or mean values, extremes are excluded, and the resulting model tends to under-estimate the low end and overestimate the high end.

This study used the first method to allocate income and auto ownership data at the block group level to the transit service areas. Income and auto ownership data are aggregated at the route segment level. Because of this aggregation, the average income at the block or block group level is not appropriate, the number of households within an income range is more appropriate.

\section{INTER-ROUTE RELATIONSHIPS}

A transit system is not a set of independent routes. A change of service and ridership in one route may have impacts on related routes. The inter-route relationship is therefore an important factor in estimating transit ridership at the route level.

From the planning point of view, an inter-route relationship is a physical relationship among two or more routes. For the purpose of modeling, an inter-route relationship is the service and ridership influence of one route upon the other. The same physical relationship may have different possible ridership impacts, for example, a service increase in one of the two routes that serve the same service areas may draw riders from the other route. It may also attract more riders from the service areas because of the total level of service increase in that area. The net effect of the service 
increase in one route may be a simple redistribution of current riders with little or no increase of total transit ridership, or a combination of redistribution and net increase of ridership. It is therefore necessary to differentiate between the inter-route physical relationship and ridership impact. The former is defined as inter-route linkages while the latter as inter-route effects in this study.

The physical relationship between two transit routes can be identified by analyzing the relationship of transit routes by their overlapping service areas (Figure 3.2). The bus route and light rail stop buffers were overlaid with each other. The interroute linkage can be identified by analyzing the overlaid areas. There are three kinds of inter-route physical linkages: independent, complimentary and competing.

If two route buffers have no overlay at any part of the routes, i.e., they are at least half a mile apart, these two routes are independent, like route 71 (RT71) and 75 (RT75) in Figure 3.2. Transferring and competition between them is unlikely because there is no overlapping area within walking distance of both. These independent routes can be treated as independent from each other in the route-level modeling. A service change in one route presumably has no impact on another.

If two route buffers overlap, they are linked. The relationship between them can be identified by the configuration of the routes and topographic constraints. Two interroute linkages can be identified: complementary and competing.

If two route buffers overlap only at one end of transit routes, such as at a transit transfer center, and the other ends are in different directions. The relationship between these two routes is considered complementary. Riders from one route may transfer to 


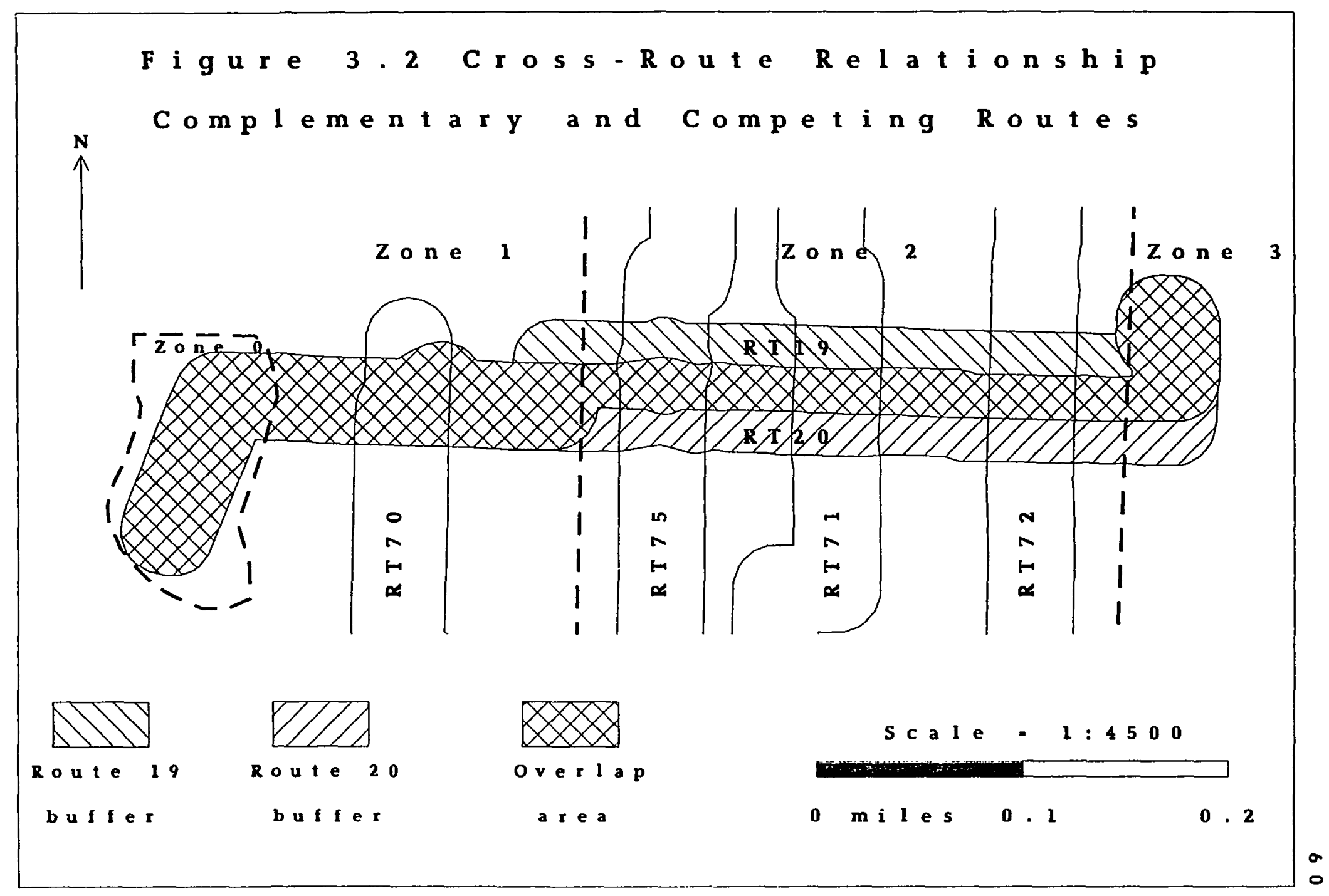


the other. A service change in one route will have a direct impact on the other. A typical example is the relationship between a radial bus and a feeder bus.

If two route buffers intersect at one point other than the ends of routes, and the two routes have different origins and destinations, such as radial bus and crosstown bus, these two transit routes are also considered as complementary. For example, route 71 and 75 are complementary routes of route 19 (RT19) and 20 (RT20) in Figure 3.2, and vice verse. Potential riders may transfer from one route to the other at the intersection point.

The common characteristics of these two types of complementary routes are that they are connected with each other at one point, at least one end of the routes is different from each other, and there are potential riders who may transfer from one route to the other.

If two route buffers overlap linearly with each other, and have at least one common end, they are considered as competing routes. Routes 19 and 20 in Figure 3.2 are examples of competing routes. Competing routes share some common service areas with each other, i.e., they run either on the same road or nearby parallel roads. One route will compete for riders with the other from the common service area. A service change on one route will affect the ridership on the other.

The relationship of two competing routes is a function of how close the two routes are to each other. If two route buffers overlap only for a small portion, the competing relationship will be small. If two routes run very closely or on the same road, these two routes will have a greater impact on each other. The area of overlap 
between the two competing routes determines the inter-route effects. Or, more precisely, the population in the overlap area of two competing routes affects the strength of the relationship between them, because it is the population that directly demand transit services. The population percentage in the overlap area of two competing routes can be conveniently estimated using GIS. It is defined as

$$
\text { OVPOPPC }_{i j z} \equiv \frac{P O P_{i j z}}{P O P_{j z}}
$$

Where, OVPOPPC $\mathrm{ijz}_{\mathrm{j} z}$ is the proportion of population in the overlap areas (POP $\left.\mathrm{PO}_{\mathrm{ij}}\right)$ to the population in the competing route buffer $\left(\mathrm{POP}_{\mathrm{j} 2}\right)$, The subscript of $\mathrm{i}$ refers to the route of interest, $j$ refers to the competing routes of $i$. The subscript of $z$ refers to the route segment or fare zone number.

The inter-route relationship discussed above assumes a homogeneous and barrier-free surface, these inter-route physical linkages have to be checked against geographical barriers, such as freeways, rivers and steep slopes. Two routes may be in parallel and their buffers overlay, but if there is a freeway or a river between them, they cannot compete for rides with each other. Potential riders cannot cross the freeway or the river to ride the bus on the other side. All bus routes have to be checked against these geographic barriers in the identification of inter-route linkages.

\section{SUMMARY}

GIS has an important role in route-level transit demand modeling. A GIS is essential to integrate different spatial data sets to support transit demand modeling. It 
is an efficient tool to achieve data consistency and to analyze inter-route relationships. Important GIS database design issues have been addressed to store and maintain spatial and temporal data for transit demand modeling.

GIS database design and spatial data analysis is used to increase the accuracy and validity of relating transit ridership and service data to demographic and employment data. The effect of this is to reduce measurement error in route-level modeling. The comparison of different data allocation methods provides a framework for analysis of spatial and attribute data allocation. Hopefully, it will promote more systematic choice of allocation methods used in GIS analysis.

This study also provides an approach to inter-route relationship analysis using GIS, which avoids double counting of population and takes into consideration interroute effects. The inter-route analysis provides a basis for a simultaneous-equations modeling analysis on interrelated routes. This also provides a useful tool for transit planning. 


\section{CHAPTER 4}

\section{SPATIAL AND TEMPORAL VARIATIONS OF TRANSIT PATRONAGE}

An important characteristic of transit ridership is its variation over space and over time. It can be observed that the transit ridership varies in different routes, directions, segments and different time periods of a day. These spatial and temporal variations of transit ridership reflect variations of travel patterns, influencing factors and their different magnitude of impacts on transit demand and supply. From the modeling point of view, these variations imply different independent variables and different coefficients for models in different space and time periods. This chapter will discuss these spatial and temporal variations of transit ridership and services, and their implications in the route-level modeling process.

\section{TEMPORAL VARIATIONS OF TRANSIT RIDERSHIP}

Transit ridership varies significantly over time, both in the long-term and the short-term time period. Public transportation usage goes up and down from year to year, because of changes in transportation policies, technology, national and local economies, costs and supplies of energy, demographic factors, urbanization and suburbanization. Monthly variations within a year are caused by seasonal variations of 
weather, student and work trip patterns. During a week, transit ridership on weekends is considerable different from weekdays. Even during an one-day period there is a large difference of ridership in different time periods. These temporal variations are caused by different factors in different time periods. To address the long-term temporal variations of yearly and seasonal changes, a time-series model is more appropriate (see Kyte, et al, 1988). A cross-sectional model can be used to address short-range changes such as those between weekends and weekdays, and variations during different time periods of a day. This dissertation will not address long-term longitudinal changes. It only deals with short-range variations. Specifically, this dissertation deals with temporal changes during different time periods of a day. It will not address transit use variations between weekends and weekdays because of lack of data.

For the purpose of transit service planning, Tri-Met divides a weekday into five time periods: morning peak (7:00am--9:00am), mid-day (9:00am--4:00pm), afternoon peak $(4: 00 \mathrm{pm}--6: 00 \mathrm{pm})$, evening $(6: 00 \mathrm{pm}--8: 00 \mathrm{pm})$ and night $(8: 00 \mathrm{pm}-2: 00 \mathrm{am}$ and 4:00am--7:00am). Each time period is associated with distinctive demands. The transit ridership variations during one day are shown in Table 4.1 .

TABLE 4.1 Ridership During Time Periods of a Day -- Spring 1990

\begin{tabular}{|l|r|r|r|r|r|r|}
\hline Time Periods & $\begin{array}{l}\text { AM Peak } \\
(7-9 \mathrm{am})\end{array}$ & $\begin{array}{l}\text { Mid-day } \\
(9-4)\end{array}$ & $\begin{array}{l}\text { PM Peak } \\
(4-6 \mathrm{pm})\end{array}$ & $\begin{array}{l}\text { Evening } \\
(6-8 \mathrm{pm})\end{array}$ & $\begin{array}{l}\text { Night } \\
(8-7)\end{array}$ & All Day \\
\hline Boarding Rides & 31,868 & 79,749 & 35,953 & 13,385 & 25,945 & 186,900 \\
\hline $\begin{array}{l}\text { Percentage of the } \\
\text { total daily } \\
\text { ridership }\end{array}$ & 17.05 & 42.67 & 19.24 & 7.16 & 13.88 & 100.00 \\
\hline Rides per hour & 15,934 & 11,393 & 17,977 & 6,693 & 3,243 & 8,495 \\
\hline
\end{tabular}


Not surprisingly, the morning and afternoon peak hours have the largest ridership on an hourly basis. In just four hours, the ridership in these two peak periods account for about 36 percent of total daily transit ridership. It is interesting to note that the afternoon peak period has more ridership than the morning peak hours. Large portion (about 43 percent) of transit usage occurs during the mid-day period, but the hourly ridership during the mid-day is only about two-thirds of the morning and afternoon peak hours. Ridership in the evening has the smallest share of the total daily ridership, and the night period has the lowest hourly ridership.

These differences in transit ridership during different time periods may be caused in large part by the different trip purposes. Transit services are stratified to serve the multiple objectives of the transit systems (Tri-Met, 1989). Transit users during the morning peak period are mostly work commuters. The concentration of work trips causes a large demand for transit services at this peak time period. Transit services are provided to facilitate workers travelling from home to work. Park-and-ride lots are most frequently utilized at this time period. Most riders board transit either near places of residence or near park-and-ride lots. Employment centers and high schools are major destinations of transit trips.

Transit riders during the midday period have the mixture of work trips and nonwork trips. Transit service is planned based on transit demand for heavily used routes and based on policy headway (the minimal headway required under some political considerations) on other routes (Tri-Met, 1989). Places of residence and work places are major origins and destinations of transit riders, with commercial areas being a 
secondary destination. High schools are other major sources of boarding riders for some routes in the late afternoon when the high school students get out of schools. Some park-and-ride lots may also be used by people in order to avoid parking charges in downtown Portland.

Transit usage during the afternoon peak period is mostly for work trips from workplaces to homes. Transit services are planned based on the transit demand to facilitate workers going home. Workplaces are dominant sources of boarding riders, and places of residence are major destinations.

Transit rides during the evening period are mostly work-related trips and some non-work trips. Transit services are provided to facilitate those later shift workers. Both work places and places of residence are major sources of boarding rides and their destinations.

During the night period many bus route services are discontinued. Those with service are major transit corridors and trunk lines. Most riders during this time period are early or late shift workers, and are usually transit dependent. Since the night service wraps around to the early morning, it also captures the beginnings of the AM peak work trips.

Because of these large differences of transit ridership in different time periods, for the same variables like population and employment, the coefficients will be different at different time periods. Some variables like income may be more significant in the models for the evening and night period than for the peak commuting hours. Models using data from different time periods cannot differentiate these different impacts and 
will result in ambiguous coefficients. This dissertation develops individual models for different time periods to capture the within-day variations of transit ridership and its determinants.

\section{SPATIAL VARIATIONS OF TRANSIT RIDERSHIP}

Transit ridership varies from route to route. Some routes have a high level of ridership and others have a lower level of ridership, because transit routes serve various places and have different functions. Ridership also varies in different directions and in different segments within a route. Ridership tends to concentrate in one segment in one direction and another segment in the reverse direction corresponding to land use patterns and trip destinations. This section discusses these spatial variations among route types, directions, and route segments.

\section{Ridership Variations Among Different Route Types}

The transit system in the Tri-Met service area is a multi-destinational transit system (Tri-Met, 1989). It is composed of two fundamental systems: a grid system and a timed-transfer system. The grid system is operated in the urban area. It is composed of a series of crosstown and radial lines with a relatively high frequency of service. Radial routes serve downtown Portland while crosstown routes do not operate into downtown.

The timed-transfer system is operated in the low-density suburban area. It is composed of feeder buses, transit centers and trunk lines. Feeder buses link suburban 
neighborhoods and business parks to suburban transit centers. These transit centers are connected with downtown Portland via trunk lines. Schedules for trunk lines and feeder lines are designed such that all buses are at the transit center at the same time, so that riders from feeder lines can transfer to trunk lines without waiting. Hence the name timed-transfer system. This timed-transfer system is designed to serve both intrasuburban and suburban-to-downtown-Portland trips.

Each line in these two transit systems serves different geographic areas and different trip purposes. Based on the functions of each transit line, all bus lines are classified as six categories: regional trunk line, crosstown, city radial, suburban radial, feeder or express.

A regional trunk line connects downtown Portland with a suburban transit center. It is served by high-frequency, high speed operation with high-capacity vehicles.

A city radial line connects downtown Portland with high-density urban neighborhoods with frequent services.

A crosstown line does not operate into downtown Portland, and it primarily serves non-downtown trips in urban neighborhoods. It has relatively frequent service but requires little or no peak-period supplementary service.

A suburban radial line links downtown Portland and suburban residential areas and provides basic area coverage.

A feeder line connects suburban residential and commercial areas with transit centers. It provides access to areas not directly accessible to trunk lines. 
An express line is provided on major corridors to provide direct services to downtown commuters in peak hours. It has limited bus stops in the middle segment of the route, and ideally operate a minimum of 25 percent faster than local service along the same line during the same time period.

In addition to these six categories of bus service, there is a light rail service. Light rail provides service between the eastern suburban city--Gresham, and downtown Portland. Light rail serves as a large trunk line, linking many feeder lines and parkand-ride lots with downtown Portland.

These transit routes have different ridership and service standards based on their service areas and functions. Table 4.2 summarizes the total daily ridership, service revenue hours and total seats supplied by route types in weekdays. Ridership is the number of boarding rides, not originating rides. The difference between boarding rides and originating rides is that boarding rides include transfers while originating rides do not include transfers. A passenger boards route 1 and transfers to route 2 is counted as one originating ride but two boarding rides. All ridership mentioned in this study is boarding rides, unless otherwise defined. Revenue hours are total hours of service. Total seats are the sum of seats in each bus line within service hours. They are not simply the product of total revenue hours and average seats in a bus line, because different capacity of vehicle may be used in peak and off-peak period for the same transit line.

Data in Table 4.2 shows that, there is a significant difference in total ridership and service supplied among different route types. City radial routes have the largest 
share of total daily ridership, they account for 45.6 percent of the total ridership, almost a half of the daily ridership. Crosstown routes come the second, sharing 16.03 percent of the total daily ridership. Light rail and regional trunk line account for $\mathbf{1 2 . 2 1}$ and 11.27 percent of the total ridership. Suburban radial, express and feeder lines have a small share of the total ridership.

TABLE 4.2 Daily Ridership and Services by Route Typology

\begin{tabular}{||l|l|l|l|l|l|l|l|l||}
\hline $\begin{array}{l}\text { Route } \\
\text { Type }\end{array}$ & $\begin{array}{l}\text { Total } \\
\text { Rider- } \\
\text { ship }\end{array}$ & $\begin{array}{l}\text { Rider } \\
\text { Share } \\
(\%)\end{array}$ & $\begin{array}{l}\text { Total } \\
\text { Rev. } \\
\text { Hours }\end{array}$ & $\begin{array}{l}\text { Rev. } \\
\text { hr. } \\
\text { Share } \\
(\%)\end{array}$ & $\begin{array}{l}\text { Total } \\
\text { Seats } \\
\text { Supply }\end{array}$ & $\begin{array}{l}\text { Seats } \\
\text { Share } \\
(\%)\end{array}$ & $\begin{array}{l}\text { Rides } \\
\text { per } \\
\text { Rev. } \\
\text { Hr }\end{array}$ & $\begin{array}{l}\text { Rides } \\
\text { per } \\
\text { Seat }\end{array}$ \\
\hline Trunk line & 21,056 & 11.27 & 446.42 & 11.10 & 23,181 & 11.91 & 47.17 & 0.908 \\
\hline $\begin{array}{l}\text { City } \\
\text { Radial }\end{array}$ & 85,233 & 45.60 & $1,678.52$ & 41.77 & 74,069 & 38.07 & 50.78 & 1.151 \\
\hline Crosstown & 29,965 & 16.03 & 731.20 & 18.20 & 31,442 & 16.16 & 40.98 & 0.953 \\
\hline $\begin{array}{l}\text { Suburban } \\
\text { Radial }\end{array}$ & 17,582 & 9.41 & 492.12 & 12.25 & 21,169 & 10.88 & 35.73 & 0.831 \\
\hline Feeder & 7,914 & 4.23 & 397.10 & 9.88 & 17,078 & 8.78 & 19.93 & 0.463 \\
\hline Express & 2,327 & 1.25 & 80.36 & 2.00 & 4,868 & 2.50 & 28.96 & 0.478 \\
\hline Light Rail & 22,823 & 12.21 & 192.73 & 4.80 & 22,765 & 11.70 & 118.42 & 1.003 \\
\hline All lines & 186,900 & 100.00 & $4,018.45$ & 100.00 & 194,572 & 100.0 & 46.06 & 0.950 \\
\hline
\end{tabular}

As to the service supply, city radial routes have the most intensive services, with 41.77 percent of total revenue hours and 38.07 percent of total seats. Crosstown routes have the second largest service share. They account for 18.20 percent revenue hours and 16.16 percent of total seats. Suburban radial routes have 12.25 percent share of total revenue hours, but only 10.88 percent of total seats; while trunk lines have 11.11 percent of total revenue hours but 11.91 percent of total seats. This indicates that 
the trunk lines have larger size vehicles than suburban radial routes. Feeder routes have about 10 percent share of revenue hours but a smaller share of total seats ( 8.78 percent) because of their smaller vehicle size. The reverse is true for light rail, it accounts for only 4.80 percent of total revenue hours but 11.70 percent of total seats.

Considering transit ridership and service supply together, the effectiveness of transit services for different route types can be compared. However, because of various measurements of service supply, the comparison of service effectiveness based on different criteria may generate different results. The effectiveness of transit service can be measured by boarding rides per revenue hour, boarding rides per seat, originating rides per revenue hour, or originating rides per seat. It can also be measured by the farebox recovery ratio (FRR), which is the ratio between all cash, ticket, and pass revenue collected from riders and the total costs of transit operations and administration, i.e., the total passenger revenue divided by the system costs.

Transit lines are not independent, so it is difficult to isolate the contribution of an individual line to the whole system. The direct contribution of a line may be how many originating rides it attracts. However, some originating rides may not use the route if there are no other routes to which they can transfer, so the originating rides are not the pure contribution of that particular route. The number of boarding rides is not a good measurement of effectiveness either, because by design some routes like regional trunk lines have more transfers than others like suburban radial routes. The ridership of several feeders will be concentrated onto one regional trunk route. Feeder lines will be under-evaluated relative to a trunk line if the boarding rides are used as 
a comparison criterion. Similarly, express routes will also be under-evaluated based on boarding rides, because there are few transfers and little turnover along the way.

The number of revenue hours is a direct measurement of operational costs. It measures most of the labor cost of bus drivers, which is the major component of operational costs. It also captures most of the variance in maintenance costs which is dependent on the distance the bus travels. But it does not include the difference of fixed costs of different vehicles. The number of total seats includes the number of revenue hours of service and the capacity of vehicles. It indirectly measures the operational costs, vehicle maintenance and fixed costs. But the operators' costs and vehicle costs are inappropriately weighted. Revenue hours are often overwhelmed by the difference of the vehicle capacity. However, the total seats is a good measurement of service supply from the riders' point of view.

The use of FRR as a criterion of comparing the effectiveness of transit service at the route level requires revenue and cost allocation to individual routes. This is a very difficult task because of the independence of transit routes and the complexity of the fare structure. The transit fare is based on the fare zone structure. No fare is needed for transit riders traveling within the fareless square. The cash fare for traveling in Zones 1 and 2 was $\$ 0.75$, and $\$ 0.95$ in all zones in 1990 . There was also a short trip fare $(\$ 0.75)$ for those transit users traveling within a single fare zone. There was no surcharges for transfers if the transferring was within two hours of the original boarding. There was also a fare of $\$ 3.00$ for all day trips. In addition, there are discount tickets and monthly passes available for all zones. It is very difficult, if not 
impossible, to allocate ticket and monthly passes to individual lines. Furthermore, because of no surcharge for transferring, those lines with lots of transfer rides will be under-evaluated based on passenger revenues. In addition, it is difficult to fully allocate fixed costs to various service types.

However, it is not the purpose of this dissertation to evaluate the effectiveness and efficiency of individual transit routes or route types. To do that requires separate study. The purpose here is to list the differences in ridership, supplied services and the resulting ridership per service unit, and to look for the homogeneity among these different types of lines in terms of ridership and services.

Based on the ridership per revenue hour, light rail is the most effective: one revenue hour generates about 118 boarding rides (Table 4.2 ). City radial, trunk line and crosstown routes are approximately in the same range: one revenue hour generates about 51, 47 and 41 boarding rides. Suburban radial and express routes can be classified as another category: one revenue hour generates 36 and 30 boarding rides. Feeder routes are the least effective. A revenue hour only generates about 20 rides.

Based on the ridership per seat, city radial lines is the most effective. One seat generates 1.15 boarding rides. It should be noted that the seat is measured by the total seats in each bus serving a whole transit line, while the boarding rides are the number of passengers that board the bus regardless of how long they stay inside the vehicle. A 1.15 rides per seat does not mean that all the seats are occupied all the time. Light rail, crosstown routes, trunk lines and suburban radial routes can roughly be classified as one category in terms of rides per seat. They generate $1.0,0.95,0.91$ and 0.83 rides 
per seat, respectively. While feeder and express routes have the least rate of rides per seat. They only generate 0.46 and 0.48 boarding rides per seat. These rates may underestimate the effectiveness of the feeder and express routes as explained before.

It is worth noting that the express bus routes are not as effective as what is expected based on the measurement of rides per revenue hour or rides per seat. This may be because the measurement of ridership is boarding rides, does not take trip length into account. Riders on express routes are usually long distance commuters. There are limited or no stops along the way to downtown Portland, and little or no turnover. The ridership is limited by the riders at the one end and by the one-time bus capacity.

From the above analysis it can be seen that route typology plays an important role in transit service design and ridership distribution. Different route typology serves various functions in the transit system. Ridership and service differ dramatically in different route types. But the difference is reduced when the ridership per service unit is estimated.

From the modeling point of view, the most important factor to decide whether these routes are homogeneous is that if the variations in the dependent variable (boarding rides) can be explained by the same factors (or independent variables). In this regard, serving downtown Portland is an important factor in grouping routes, because the huge downtown employment could overwhelm other factors, and downtown Portland is the most important attraction of many transit trips. Therefore, routes that operate into downtown can be aggregated into one group, while routes that do not serve 
downtown (i.e., crosstown and feeder routes) can be grouped as another group.

The second important factor to consider is whether the same service generates the similar ridership. If the same service does not generate the similar ridership, it implies that the coefficient for the service variable may not be the same. The routes are not homogeneous. Therefore, express routes cannot be grouped together as other routes that operate into downtown. Crosstown and feeder lines have to be treated separately in the model too.

Based on these considerations, this study classifies city radial, trunk line, suburban radial lines and light rail as one group--radial routes, crosstown routes as another category, and feeder routes as the third category. The express lines are different from all other routes in that the rides concentrate only on one end of the route. They should be modeled separately. Because there are only four express routes, there are not enough observations to estimate the model. They are excluded from the model. A special model is needed to address the express routes.

Different models could be developed separately for these three categories, assuming the coefficients of variables are different. One problem of this approach is that there may be too few observations for some route types. Another approach is to put all routes into one model, and using the route type dummy variable and its interactions with other variables to differentiate the differences of route types. Statistical tests can be used to test the significance of the differences among these various route types. 


\section{Directional Variations}

The direction of transit routes is determined based on the relationship with Downtown Portland. For a route that operates into downtown (like radial routes), heading towards downtown Portland is defined as inbound, while moving away from downtown Portland is defined as outbound. For a feeder route, the direction is defined in relation to the route or transit center it feeds. The direction of going towards the trunk line or transit center is defined as inbound, while the direction of moving away from the trunk line or transit center is outbound. For a crosstown route, the inbound and outbound direction is somewhat arbitrary. This study defines all crosstown routes as the inbound in the morning peak hours and as outbound in the afternoon peak hours, because many riders on crosstown routes transfer to radial routes to downtown in the morning peak period, and transfer to radial routes away from downtown in the afternoon peak period.

Theoretically, the total transit ridership should be balanced in two directions. People who take the bus to work usually take the bus home. The observed data in Table 4.3 show that the inbound direction has a little more ridership than outbound, but they are roughly balanced. The big difference in ridership lies in different time periods of a day, not the aggregated daily ridership (Table 4.3). The transit ridership in the inbound direction is about twice the number in the outbound direction in the morning peak hours. The reverse is true in the afternoon peak hours. The ridership during the mid-day is almost balanced for the two directions. Outbound ridership in the evening is about 1.5 times of inbound ridership, indicating most riders are late workers 
traveling home. But the reverse is true for the night period, implying most transit usage is early morning work trips going to work.

There are different factors affecting transit ridership in two directions. Most transit riders board inbound routes at their places of residence. Some drive to park-andride lots first and take the bus from there. Therefore, population, the characteristics of the place of residence, and the park-and-ride lot usage, as well as transfers and transit services are important factors that determine the boarding rides in the inbound direction.

In contrast to inbound riders, most outbound riders board buses at the places of employment. The large employment density implies a big activity attraction center, and determines the number of work trips and shopping trips. It is the amount of employment, especially the employment density, that determines the boarding rides in the outbound direction. Since not all employment is located in the downtown area, some riders may also ride outbound buses to go to suburban destinations, so the population and the characteristics of the place of residence are also important determinants of outbound ridership.

TABLE 4.3 Transit Ridership at Time Period of a Day by Directions

\begin{tabular}{||l|r|r|r|r|r|r||}
\hline \hline Direction & AM Peak & Mid-day & PM Peak & Evening & Night & All Day \\
\hline Outbound & 10,313 & 40,078 & 23,254 & 7,956 & 9,979 & 91,840 \\
\hline Inbound & 21,555 & 39,671 & 12,699 & 5,429 & 15,975 & 95,060 \\
\hline Total & 31,868 & 79,749 & 35,953 & 13,385 & 22,954 & 186,900 \\
\hline
\end{tabular}


Since ridership in inbound and outbound directions is determined by different factors, two separate models need to be developed to reflect these differences.

\section{Variations Among Fare Zones}

The basic spatial unit of observation of this study is the route segment, segmented by fare zones. In the Tri-Met service area, there are four fare zones: fareless square (zone 0), zone 1 , zone 2 , and zone 3 based on the transit fare structure. These four fare zones are concentric squares surrounding the downtown Portland (Figure 4.1).

Transit ridership varies among these fare zones (Table 4.4). Most transit riders board transit in Zone 2. Boarding rides in Zone 2 account for about one-third $(33.02$ percent) of the total daily ridership without considering direction. Zone 0 comes the second (29.17 percent). Followed by Zone 3 (20.07 percent). Zone 1 has the least share (16.74 percent) of the total daily ridership because of its relative smaller size compared with Zones 2 and 3 (see Figure 4.1).

These zonal effects are also affected by direction. For the outbound direction, boarding rides are dominant in Zone 0 , the downtown employment center. More than half of outbound rides (about 51 percent) board transit in Zone 0 . Boarding rides in Zone 2 account for about 22 percent of outbound rides. Zone 1 and 3 have only a small portion of outbound boarding rides. For the inbound direction, a little less than half (about 44 percent) of the rides are from Zone 2. Zones 3 and 1 account for another half of the ridership (about 27.4 and 20.5 percent, respectively). Boarding rides in Zone 0 


\section{F I G U R E 4 . I}

T r a n i $t$ Rou t e a n d F a r e Z o n e s

Port la $n d, \quad 0 r$ e g $n$, ( 1990$)$

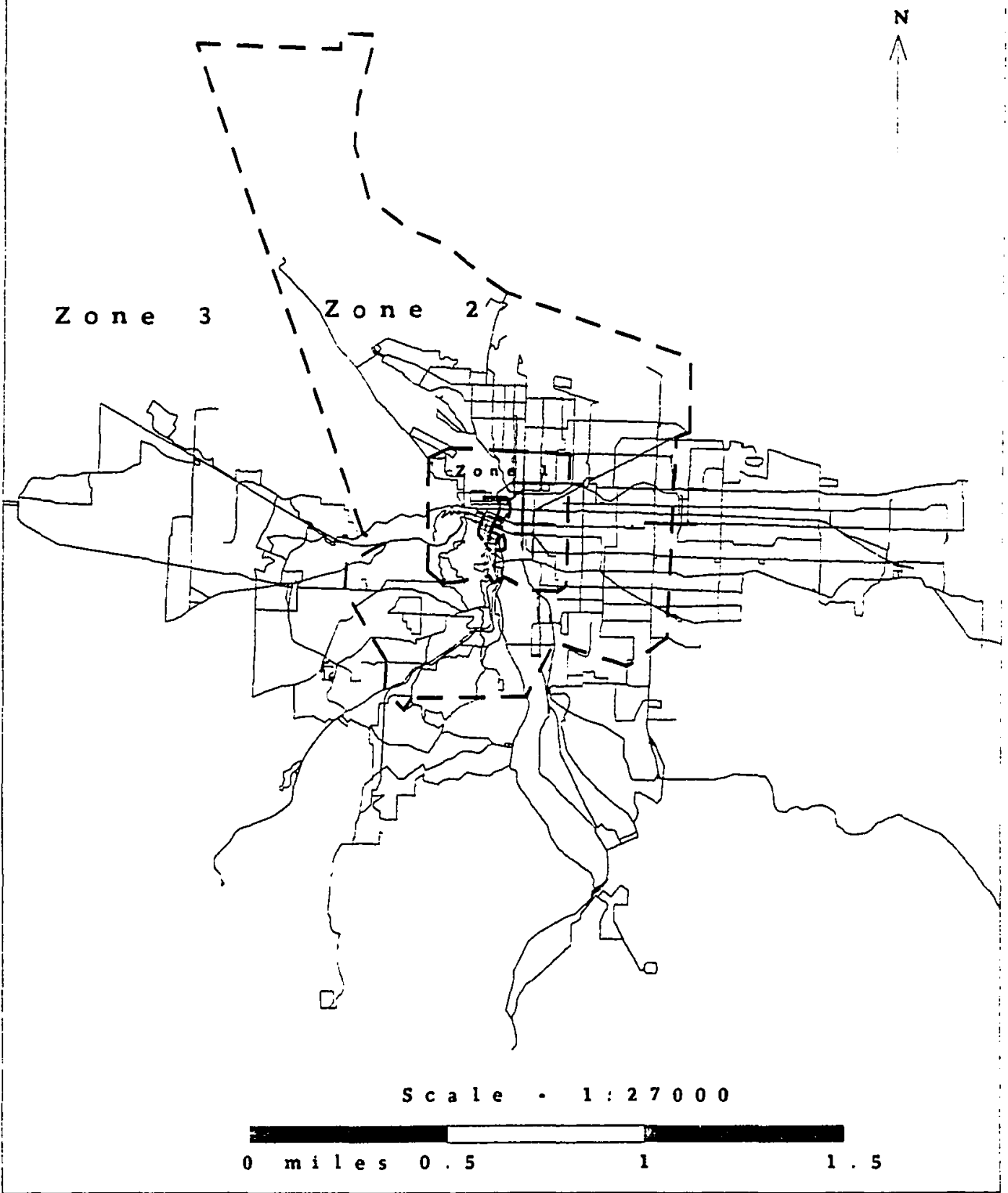


is very small (only about 8 percent). These observations are consistent for all time periods as illustrated in Table 4.4.

TABLE 4.4 Transit Ridership on Fare zones

\begin{tabular}{||r|r|r|r|r||}
\hline \hline Direction & $\begin{array}{l}\text { Fare } \\
\text { Zone }\end{array}$ & \multicolumn{1}{l|}{$\begin{array}{l}\text { Daily } \\
\text { Rides }\end{array}$} & $\begin{array}{l}\text { Zone Share within } \\
\text { One Direction (\%) }\end{array}$ & $\begin{array}{l}\text { Zone Share of All } \\
\text { Directions (\%) }\end{array}$ \\
\cline { 2 - 6 } Outbound & 0 & 46,749 & 50.90 & 25.01 \\
\cline { 2 - 6 } & 1 & 11,829 & 12.88 & 6.33 \\
\cline { 2 - 6 } & 2 & 19,963 & 21.74 & 10.68 \\
\cline { 2 - 6 } & 3 & 13,299 & 14.48 & 7.12 \\
\hline \hline \multirow{3}{*}{ Inbound } & All zone & 91,840 & 100.00 & 4.16 \\
\cline { 2 - 6 } & 0 & 7,775 & 8.18 & 10.41 \\
\cline { 2 - 6 } & 2 & 19,453 & 20.46 & 22.34 \\
\cline { 2 - 6 } & 3 & 26,075 & 43.93 & 13.95 \\
\cline { 2 - 6 } & All zone & 95,060 & 27.43 & 100.00 \\
\hline \hline \multirow{3}{*}{ Total } & & 186,900 & 100.00 & \\
\hline \hline
\end{tabular}

The variations in ridership among fare zones are the result of many causes. As discussed above, the outbound ridership is dominated by the downtown employment. The concentration of employment in downtown Portland could explain the large share of transit ridership in Zone 0 . For the inbound direction, the zonal variation of transit ridership is caused by many other factors, such as the transit fare, the distance to downtown, the costs and availability of parking, land use characteristics, and selfselection of residential choices.

Different fares are charged in different fare zones as explained before. The fare 
zone structure can be considered as a proxy of fare structures. The concentric fare zone structure is also a surrogate for the distance to downtown. From zone 0 to zone 3 , the distance to downtown increases. Most of areas in fare zones 1 and 2 are in the inner city, while zone 3 is basically in the suburbs. The distance to the downtown is an important factor affecting transit use. The closer one is to the downtown, the more likely one is to use transit, because of the shorter travel distance. Due to the selfselection process, a resident who is more pro-transit is also more likely to choose his/her residential location closer to downtown, i.e., in Zones 1 and 2. The shorter distance and more frequent transit service will reduce the relative disadvantages of transit use compared to auto use. The fare zone structure may capture this effect in the model.

Parking is not free in the entire fareless zone and a parking license is required in part of Zone 1. To avoid the downtown parking charges, some drivers park their cars in the park-and-ride lots provided by Tri-Met and ride transit to downtown, while others park their cars in some residential neighborhoods in zone 1 (this is sometimes called informal parking) and take the bus there or walk to the fareless square to take the bus. The park-and-ride usage can be partially captured in the model by including the park-and-ride lot capacities in the model. The informal neighborhood parking in zone 1, however, cannot be incorporated in the model because of the lack of data, which could be captured by the zone dummy.

In addition, the variation of transit ridership among fare zones is also caused by other factors like land use characteristics. Land use density, transit-oriented design, and 
lower income neighborhood in Zones 1 and 2, may also contribute to the larger shares of transit uses in inner city zones.

Because of the zonal variations of boarding rides, using the fare zone as the basic spatial observation unit has an important implications for transit planning and transit demand modeling. The use of the fare zone as the basic observation unit can capture the spatial variations, while the use of the entire route as the basic unit cannot. As is observed, for a transit route that goes across four fare zones, transit riders may mainly come from Zones 2 and 1 . The ridership aggregated at the route level will be unable to identify the major sources of boarding rides and its causes. Therefore, using the route segment (fare zone) as the basic unit in transit demand modeling has its advantage over using the whole route as the basic observation unit.

However, there are some limitations of using the segment as the basic observation. The first limitation is that the length of each segment or the size of each fare zone is not equal. For example, Zone 1 is much smaller than Zone 3 . This is the major reason that the total ridership in Zone 1 is less than Zone 3 . To avoid this problem, the length of a transit route in each segment could be included in the model implicitly, or using the density variable such as ridership per mile and seats per mile. This study originally included the segment length in the model to take into account this variation, but it is highly correlated with the total population variable. The longer the route, the more population it serves. Since the measurement of population is a more direct estimate of transit demand, this study includes only the population variable not the route length in each route segment in the model. 
The second limitation is that not all routes serve every fare zone because of the route configuration. Some routes serve only one or two fare zones, especially for those crosstown and feeder routes. Most routes serve four fare zone and have four route segments.

The third limitation is that the transit service variable is harder to measure at the segment level. In most cases, the service frequency and hours of service are the same for a transit route throughout all fare zones. A few routes operate more frequently over a portion of the line than over the entire line. On time performance at transit stops has to be aggregated to the route segment.

Lastly, using the route segment as the basic observation unit makes it harder to analyze inter-route relationships (see Chapter 3). Two routes may compete with each other in only part of a segment. There are some diagonally oriented routes which intersect and compete with different routes in different subsegments. To take these inter-route effects into account, aggregation is needed. In the process of aggregation, some variations within a route segment are reduced.

Because of these limitations, a stop level model is more appropriate than a route segment model. A stop level model, however, requires more reliable and accurate data than is available, and requires more detailed data allocation as explained before. Therefore, the route segment rather than transit stop is used as the basic observation unit in this study. Further study needs to consider using stop level data to develop transit demand models. 


\section{SUMMARY}

Considering these temporal and spatial variations of transit ridership, this study develops ten models for five time periods and two directions of each time period. The basic spatial observation of models is the fare zone. Two kinds of dummy variables are used in the models: the route typology dummy and fare zone dummy to take account of the variations in different route types and fare zones. The total seats supplied at each fare zone is used as the service quantity variable, because the number of total seats is a direct measurement of seating capacity. The average on time performance at a fare zone is used as a service quality variable. These route and zone dummy variables and service variables are common in all models. The demographic and other variables are different in different models.

For inbound models, the common demographic variables are population and household income. In addition to these two common variables, there are park-and-ride lot capacity and high school student enrollment for the morning peak and mid-day period.

For outbound models, the common demographic variables, for all but morning peak period models, are employment density, population density, population downstream (total population at all downstream fare zones) and household income. In addition, there is a high school student enrollment variable in mid-day model. For the Morning peak outbound model, employment density should not be an independent variable, because unlike other time period, downtown employment does not cause transit ridership at zone 0 in the morning peak period. Therefore, the variables used 
in the outbound model in the morning peak period are population, population density, income and high school student enrollment.

The major difference between inbound and outbound models is that the inbound models only include population and income at the place of residence, because most transit riders board transit at the place of residents, some park-and-ride users are picked up by the park-and-ride lot capacity. While outbound models (except for the morning peak period) include employment density and population downstream, because it is the employment density and population downstream that determine the outbound boarding rides most of the time. Park-and-ride lot capacity has no impact on outbound boarding rides in the zones where park-and-ride lots are located, it can affect the alightings on that zone but not boarding rides. 


\section{CHAPTER 5}

\section{AN ANALYSIS OF A SIMULTANEOUS TRANSIT SYSTEM}

\section{INTRODUCTION}

A transit system is composed of an agency that supports transit service, transit users and a transit route network. The transit agency plans a transit network and supplies transit service, transit riders utilize supplied services, and a transit network facilitates the integration of transit service supply and transit users. These three components are interdependent. Transit service and network are planned based on transit ridership, transit ridership is affected by the level of service and the interrelationships of routes in the route network. Ridership changes further affect the level of service and the alignment of the network. Therefore, a transit system can be considered as a simultaneous system as shown in Figure 5.1.

The diagram in Figure 5.1 shows a simple flow in the

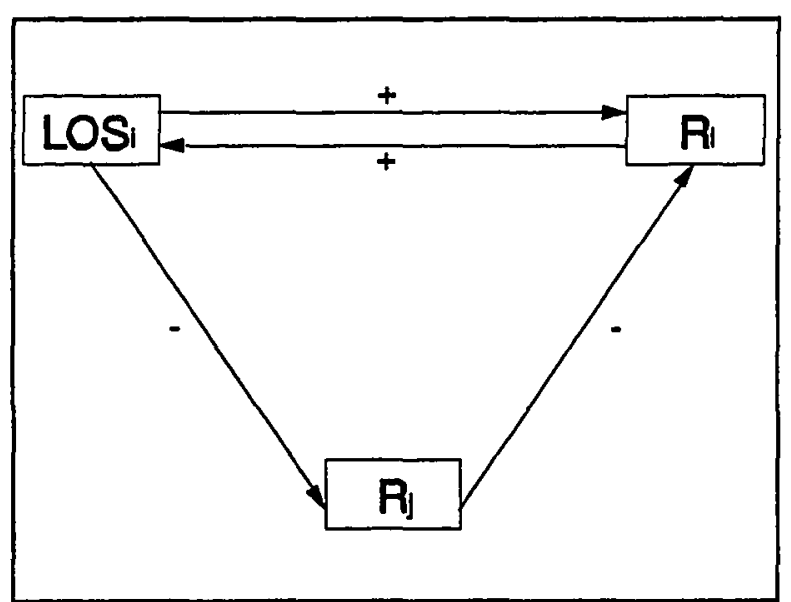

Figure 5.1. Internal Variable Flow in A Transit System simultaneous transit system. Level 
of service of a subject route $i\left(\operatorname{LOS}_{i}\right)$ affects the ridership on that route $\left(R_{i}\right)$ and the ridership of its competing routes $j\left(R_{j}\right)$, the routes that are on the same or closely parallel roads with the subject route $i$. The change of ridership on the competing routes also affects the ridership on the route $i$. In other words, the level of service on the route of interest $\left(\operatorname{LOS}_{i}\right)$ influences ridership on the route $i\left(R_{i}\right)$ in two ways: a direct effect and an indirect effect. Level of service can directly affect ridership, it can also affect ridership indirectly through ridership changes in the competing routes. The ridership changes on the route $i$ in turn influences the supply of service $\left(\operatorname{LOS}_{i}\right)$ on that route.

The simple flow shown in Figure 5.1 is only an internal flow of the transit supply (level of service) and transit demand (ridership), it does not take factors outside the transit system (exogenous variables) into account. The level of service supplied does not depend on the current ridership alone, and the ridership is not just affected by the level of service. There are many other factors that affect both transit service supply and demand. Those general exogenous variables are shown in Figure 5.2.

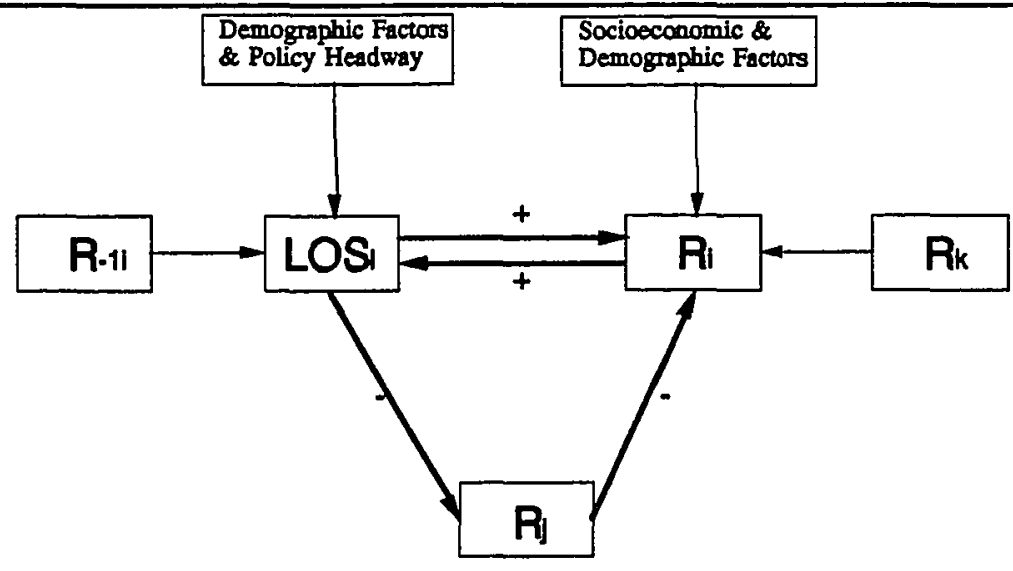

Figure 5.2. General Factors Influencing Transit Demand and Supply 
The service supply and distribution among routes are determined by the current ridership $\left(\mathrm{R}_{\mathrm{i}}\right)$, ridership in the previous planning year $\left(\mathrm{R}_{-1 \mathrm{i}}\right)$, socioeconomic and demographic factors, and some political considerations. Route level ridership $\left(R_{\mathrm{i}}\right)$ is affected by the level of service on the route, the total ridership on the competing routes $\left(R_{j}\right)$ and the complementary routes $\left(R_{k}\right)$, and socioeconomic and demographic factors. The total ridership on the competing routes $\left(R_{j}\right)$ is affected by the level of service on the route $i$ and route $j$, as well as the degree of interaction among routes, which is measured by the percentage of population in the overlap area with route $i\left(O V P O P P C_{i}\right)$.

This interacting transit system can be represented by a simultaneous-equations model, expressed by the following three equations:

Demand Equation:

$$
R_{i}=F\left(\operatorname{LOS}_{i}, \sum_{j} R_{j}, \sum_{k} R_{k}, X_{i}^{d}\right)
$$

Supply Equation:

$$
\operatorname{LOS}_{i}=F\left(R_{i}, R_{-1 i}, X_{i}^{s}\right)
$$

Equation for Competing Routes:

$$
\sum_{j} R_{j}=F\left(\operatorname{LOS}_{i}, \operatorname{LOS}_{j}, \text { OVPOPPC }_{i}\right)
$$

Where, $X_{i}^{d}$ and $X_{i}^{s}$ are a set of socioeconomic and demographic variables. The following sections in this chapter will discuss in detail the factors and the structures of this simultaneous-equations model. Section II addresses the simultaneity of transit demand and supply, and describes the simultaneous decision-making process of transit riders and service planners and schedulers. Section III discusses the inter-route 
relationship among transit routes in the transit network, and analyzes the possible impacts of service changes of one route on the other routes, as well as the ridership impacts of one route upon the other.

\section{SIMULTANEITY OF TRANSIT DEMAND AND SUPPLY}

Transit demand and supply is an interdependent process. Transit demand depends on transit service supply, while transit supply depends on transit demand.

But this interdependence between demand and supply does not imply demand and supply can adjust instantaneously. It takes time for transit planners to respond to demand changes and for transit users to respond to service changes. However, there is little documented evidence about response times for transit service changes and ridership changes.

Cherwony and Polin (1977) fits logistic growth curves to the early growth in patronage on a number of newly established bus routes. They found that 99 percent of the ultimate stable ridership level would be achieved in periods ranging from about 3 months to 7 months after inauguration, with a median growth time of roughly 5 months. For a marginal service change such as headway changes on an existing route, there is no report on its possible response time.

There is two different opinions about the response times of service supply on ridership changes. Gaudry (1975) argues that for the specific bus systems the service supply is unlikely to have been influenced by the current level of demand, it is generally fixed once a year at the time of budget planning. In contrast, Alperovich, et 
al (1977) argue that such limiting cases may exist, in general transit managements usually have the flexibility to make both short-run and long-run adjustments in service supply to match the expectations of demand. Therefore, in Gaudry's supply equation, only the ridership in previous planning year is considered to influence transit supply. While in the Alperovich, et al's supply models, both current and previous ridership are considered as factors affecting service supply, but the authors admit that if the transit agency is reasonably adept at predicting patronage levels, the inclusion of current demand in the supply function may make the past demand data superfluous.

This study considers transit demand and supply as both recursive and simultaneous. On the one hand, the relationship between ridership and level of service is recursive because there is a lagged time period for transit services and transit users to respond to the changes of each other. It may take several months for transit riders to respond to a service change. A major service change occurs only once a year, which is based on the observed ridership on the time of planning and the planners' expectation of future ridership. On the other hand, if the available data are averages over a long period (longer than the response time), the transit ridership responses can be considered simultaneous with service changes. And the transit planners have the flexibility to adjust short-run demand changes and their expectations of future ridership are rational, the service supply could be simultaneous with transit demand. In other words, the service planning could be based on both the previous year's ridership (recursive models), and the current ridership (simultaneous models). This simultaneous system can be represented by the following regression model: 


$$
\begin{gathered}
R_{i z}^{d}=F\left(S_{i z}^{s}, X_{i z}^{d}\right)+\varepsilon_{i z} \\
S_{i z}^{s}=F\left(R_{i z}^{d}, R_{-1 i}, X_{i z}^{s}\right)+\eta_{i z}
\end{gathered}
$$

Here $R_{i z}{ }^{d}$ and $S_{i z}{ }^{s}$ are observed transit ridership and service variables, representing transit demand and supply at route $i$ and fare zone $z . R_{.1 \mathrm{i}}$ is the ridership at previous planning year. The demand function will describe the transit riders' decision-making process. A theory of transit riders' behavior suggests the function form of $R_{i z}{ }^{d}($.$) and the vector of explanatory variables X_{i z}{ }^{d}$. The supply function will describe the transit planners' or schedulers' decision-making process. A theory of transit planners' behavior suggests the function form of $\mathrm{S}_{\mathrm{i} 2}{ }^{\mathrm{S}}($.$) and the elements of vector of$ determinant variables $\mathrm{X}_{\mathrm{iz}}^{\mathrm{s}}$, and $\epsilon$ and $\eta$ are stochastic error terms.

The major role of the simultaneous equation model is to reflect the interrelationship and feedback between transit ridership and level of service and obtain efficient and consistent parameters of exogenous and endogenous variables including level of services. This cannot be achieved by any single-equation models.

\section{Transit Demand}

There are many factors affecting the demand for transit service, such as people's attitudes toward public transportation, socioeconomic and demographic characteristics of local residents, land use patterns, commuting patterns, and transit service quantity and quality.

At the individual level, the transit riders can be classified as choice riders and 
captive riders. A choice rider is one using transit by choice, who rides transit not because he/she has to but because he/she prefers to. A captive rider is one whose only mode choice of travel is transit. For a choice rider, his/her attitude toward transit is the major factor affecting his/her choice in using transit, coupled with his/her socioeconomic characteristics and commuting patterns. For a captive rider, his/her socioeconomic characteristics and physical constraints are major factors.

Attitude toward transit use is very important for a choice rider. In Tri-Met's market segmentation study (Tri-Met, 1993), about 87 percent of transit riders (defined as two or more rides per month) are generally pro-transit, or have positive attitude toward transit usage. With the same transit attitude, however, there is a difference in real behavior, some people frequently use transit while others rarely do. This can be partially explained by the place of residence, the place of employment, the difference of gender, age, income, car ownership, the availability and the level of transit service. It should be emphasized here that these factors are not the only factors that influence people's mode choice. Even for the same socioeconomic and demographic characteristics and transit services, some people use the transit service, while others will not regardless the level of transit service. Using these factors can only explain part of the observed transit ridership variations.

Places of residence play an important role in determine residents' travel behavior. There is a significant difference of transit usage for residents living in Multnomah, Clackamas and Washington counties in Portland metropolitan area. Most transit riders live in Multnornah county, residents in Clackamas and Washington 
counties have fewer riders. The location of three counties can be a proxy to the distance to downtown. Downtown Portland is located in Multnomah county, while Clackamas and Washington counties are farther from downtown. This is consistent with the ridership observations in different fare zones (See Chapter 4). Residents of Clackamas and Washington counties often perceive long commuting trips as the main reason for using less or not using transit (Tri-Met, 1993).

The place of employment is another important factor affecting commuters' mode choice. Working or studying in downtown is a major discriminator between transit users and nonusers who have the same attitude toward public transportation. People working and studying in the downtown area are more likely to use transit.

Furthermore, women are more likely to use transit than men, the young are more likely to use transit than the old. The income effect is mixed, with high, medium and low incomes being both transit users and non-users. However, there is a tendency for lower-income and fewer-car households use more transit.

In addition, the quantity and quality of transit service affect the transit demand. Convenience, waiting time, security and safety are identified as major factors (Tri-Met, 1993). Most people are willing to take public transportation if it is convenient in terms of ease of transferring, ease of carrying packages and having a seat to sit down. Waiting time implies service frequency and on time performance, and is a major concern of most people. Security and personal safety are other concerns of many transit users.

At the aggregate fare zone level, variations of some of these factors are reduced 
and some of the factors are not available. Attitude data, an important factor affecting individual mode choice, is not available at the fare zone level. Gender and age are important factors affecting individual choices, but it may not be significant in aggregation, because there is little variation of gender and age difference among fare zones. The total population, rather than the gender proportion and age structure, is more appropriate at the aggregated level.

Security and safety issues are often mixed with other variables at the aggregate level. Crime is usually associated with low income and high density land use areas, where transit ridership is also high. Simply relating crime rate and transit ridership will generate a positive relationship, with a high crime rate associated with high ridership. This is a spurious relationship. Also, perceptions of poor security may not be correlated with areas where security is actually a problem. But perceptions are harder to be quantified. Security and safety are more appropriate to be addressed at the disaggregated individual level, or using a stated preference survey method.

The convenience and waiting time can be approximated by the service frequency (service quantity) and on time performance (service quality). Frequent service will reduce waiting time and increase seat availability. Good on time performance will make it easy to transfer and may reduce transferring and waiting time too. But the measurement of on time performance is difficult at the aggregated level. On time performance on each transit stop has to be aggregated at the fare zone level for a time period. Variation is reduced in this aggregation process. And this average on time performance cannot reflect the service quality. Furthermore, the importance of on time 
performance also depends on the frequency of service. For a route with one bus per hour, on time is very important. While for a route with a service of every ten minutes, on time is not so important. Because of the problem of measurement, on time performance is not significant in the model and has been dropped from the model estimation.

In summary, the aggregate demand for transit depends on the transit service quantity and quality, and socioeconomic and demographic characteristics of residents in the transit service area. The transit demand equation without considering inter-route effects is expressed by Equation (5.6).

$$
\begin{aligned}
& R_{i z}=F\left(\operatorname{LOS}_{i z}, X_{i z}{ }^{d}\right) \\
& X^{d} \in\{\text { POP, INC, EMPDEN, PARK, HSCH }\}
\end{aligned}
$$

Where,

$$
\text { LOS }_{\mathrm{iz}} \equiv \frac{\text { SERVICE TIME }_{\mathrm{iz}}}{\text { HEADWAY }_{\mathrm{i} z}} * \text { SEATS PER BUS } \mathrm{i}_{\mathrm{i} z}
$$

$\mathrm{R}=$ Boarding rides.

SERVICE TIME $=$ the total minutes of service in a service time period, such as AM peak, midday, PM peak.

HEADWAY is the time interval between two buses in a bus route, i.e. the number of minutes per bus. The service time over headway is the total number of buses served during a time period. Therefore, the LOS variable is the total number of seats supplied during a time period.

$\mathrm{X}^{\mathrm{d}}$ is a subset of socioeconomic and demographic variables. These variables are different in different time period and directional models.

$\mathrm{POP}=$ Population within a transit service area. A service area is defined as a 
quarter mile distance around a bus route or a quarter mile circle around a light rail stop.

INC $=$ Number of households with income less than $\$ 25,000$ within the route buffer. The median income in Portland Metropolitan area is about $\$ 30,000$, the $\$ 25,000$ represents the lower than median income range. acre.

EMPDEN = Employment density, expressed by the number of employees per

PARK = Total number of parking spaces used in park-and-ride lots within a bus route buffer. This is a survey data from Tri-Met, and allocated to the route buffers using GIS. They are differentiated between Tri-Met owned lots and some church lots.

HSCH $=$ High school enrollment of those high schools inside a transit route buffer not served by school buses.

The subscript i represents the route of interest, while $\mathrm{z}$ represents the fare zone.

\section{Transit Supply}

It is hard to clearly define the objectives of a publicly-owned and subsidized transit system. Little empirical investigation has been reported in the literature. However, as Alperovich and his colleagues (1977) point out, in spite of the absence of profit-maximization motives, transit agencies are generally responsive to both changing demands and community requests, and their supply behavior is likely to reflect this. And the flexibility to adjust supply is usually limited by rigid budget constraints which may be more or less independent of current transit demand and supply considerations.

The general mission of Tri-Met is to assure people increase mobility in a compact urban region. This mission and six goals are summarized in the "Tri-Met Service Standard" (Tri-Met, 1989). The six goals are briefly stated as follows: 
"Goal 1. Steadily increase system reliability and decrease the number of customer complaints.

Goal 2. Increase transit ridership to 325,000 riders per day by 1998 .

Goal 3. Attract, train and retain 2,600 employees by 1998 who will provide superior customer service.

Goal 4. Steadily decrease the cost of each originating ride provided, maintain the equivalent of three month's working capital, and increase the continuing annual revenue base $\$ 45$ million by 1995 .

Goal 5. By 1998, expand and diversify service to 1,010 buses and mini-buses and two operating rail corridors, with two rail corridors in construction and one in advanced design. Double the percentage of carpool, bike and walk trips.

Goal 6. Using public and private partnership, help assure that a majority of all new housing and jobs inside the region's Urban Growth Boundary (UGB) are served by the primary transit network within a 5-minute walk (Tri-Met, 1989, p.2)."

To achieve these goals, the service supply on the route level is determined by demand and policy in Tri-Met (Tri-Met, 1989). During peak hours, service is scheduled to accommodate actual passenger volumes based on vehicle loading standards. During off-peak periods, the service level is mostly determined by policy considerations.

\section{The Standard of Level of Service -- Loading Standards}

The loading factor is the number of passengers on a vehicle divided by the vehicle's seating capacity. A bus carrying full-seated passengers but no standees has a load of 1.0 or 100 percent. Service on a route is designed so that average loading factor does not exceed the applicable loading standard during each specific time period. During off-peak hours, the loading standard states that service should be scheduled so that every passenger is offered a seat (Tri-Met, 1989). When more than two consecutive off-peak trips on a line consistently exceed a seated load outside downtown 
Portland, service should be adjusted to reduce passenger crowding.

During peak periods, the loading standards are shown in Table 5.1. That is, service should be provided so that the passenger load factors shown in Table 5.1 are not exceeded. Load factors greater than 100 percent should not exceed 20 minutes when the vehicle is outside the fareless square (zone 0). This implies that, for an outbound route serving downtown, the bus should be free of standees by the time it has traveled 20 minutes or more from the edge of downtown.

TABLE 5.1 Passenger Loading Standards

\begin{tabular}{||l|r|r|r|r||}
\hline \multirow{2}{*}{ Vehicle Type } & \multicolumn{3}{|c|}{ Passenger Capacity } & \multirow{2}{*}{$\begin{array}{c}\text { Load Factor } \\
\text { (Percentage) }\end{array}$} \\
\cline { 2 - 5 } & Seated & Standing & \multicolumn{1}{c|}{ Total } & 130 \\
\hline Small Bus & 25 & 8 & 33 & 145 \\
\hline Standard Bus & 44 & 20 & 64 & 173 \\
\hline Articulated Bus & 64 & 47 & 111 & 218 \\
\hline Light Rail Vehicle & 76 & 90 & 166 & \\
\hline
\end{tabular}

Source: "Tri-Met Service Standards," Table 2, P.13 (Tri-Met, 1989).

\section{The Standard of Level of Service -- Policy Headways}

During off-peak hours, passenger demand typically does not exceed seated capacity, so the loading standard is no longer applicable, and policy headways should then apply. Headway is the time interval between two consecutive buses serving a route, and it is usually represented by number of minutes per bus. Frequency is the number of buses per hour, and it is the reciprocal of headway measured in hours. For example, if the bus service is every 15 minutes a bus, the headway is 15 minutes, but 
the frequency is 4 buses per hour.

The policy headway is the minimal headway under which a transit route should operate. It varies for each route type at different time periods (Table 5.2). The standards of policy headways have been set somewhat arbitrarily, mostly based on the route functions and service areas. Policy headways are presumably the threshold of minimal service so that the choice riders are likely to use the service. They are intended to ensure that a transit line taps the largest number of potential transit users. Although policy headways are not rigid, service should generally operate according to the service standard specified in Table 5.2. For poorly-performing routes, service may be less than that described by the policy headway after a careful evaluation of those routes.

TABLE 5.2 Policy Headways for Weekdays

\begin{tabular}{|c|c|c|c|c|}
\hline & $\begin{array}{l}7-9 \mathrm{am} \text { and } \\
4-6 \mathrm{pm} \\
\text { (Peak) }\end{array}$ & $\begin{array}{l}6-7 \mathrm{am} \text { and } \\
9 \mathrm{am}-4 \mathrm{pm} \\
\text { (Base) }\end{array}$ & $\begin{array}{l}\text { 6-9:30pm } \\
\text { (Evening) }\end{array}$ & $\begin{array}{l}\text { 9:30pm- } \\
\text { Mid-night } \\
\text { (Night) }\end{array}$ \\
\hline \multicolumn{5}{|l|}{ URBAN GRID } \\
\hline Regional /Urban Trunks & 10 & 15 & 15 & 30 \\
\hline City Radial & 15 & 15 & 30 & 60 \\
\hline Crosstown & 15 & 15 & 30 & - \\
\hline \multicolumn{5}{|c|}{ SUBURBAN TIMED-TRANSFER } \\
\hline Regional Trunks & 15 & 30 & 30 & 60 \\
\hline Suburban Radial/Feeders & 30 & 30 & 60 & - \\
\hline Peak-only Radial/Feeders & 30 & - & -- & -- \\
\hline
\end{tabular}

Source: "Tri-Met Service Standards," Table 1, P.9 (Tri-Met, 1989). 


\section{Service Adjustment Process}

Service standards are applied and evaluated periodically. Based on the review and evaluations of route performances according to service standards and service requests, transit service is adjusted accordingly. Service is adjusted to accommodate changes in passenger demand, to respond to service requests from customers or communities, and/or to overcome specific operating problems such as overloads or schedule adherence problems. Major service changes occur in September, concurrent with the issuance of new timetables and the "Tri-Met Guide," a detailed service schedule for all transit routes and other passenger information. Minor schedule changes of up to plus-or-minus three minutes and minor route changes may be implemented as necessary any time, without the reprinting of public timetables, although public notices may be printed. More significant changes (i.e., changes greater than plus-or-minus three minutes) and major route changes will be implemented only in September. Route and schedule changes that require a public hearing are also made only in September. Major changes which are not apparent to the public but effect transit operations may occur in November, January, April and June.

In addition to the service adjustments at fixed times, there is also an on-going fine-tuning process to analyze schedule efficiency and patronage changes. This includes adjustments to schedules, the elimination and addition of selected trips, changes in through-route combinations and minor route changes. This ongoing analysis and evaluation are made through discussions with operators, road supervisors and other 
staff members.

Furthermore, anticipated land use or employment level changes are also reviewed to determine whether an increase in patronage can be expected. For example, if a new shopping center were scheduled to open along an existing line, then the service might be changed in anticipation of future increase of patronage.

Service supply is also constrained by the available budget. Transit services have been increased or reduced in most transit agencies according to budget variations over time. The budget of transit service varies in the long-term but could be stable in the short-term, such as one to three years. The total transit budget in such a short time period can be treated as constant. Most budget for Tri-Met is from the payroll tax, it is relatively stable in a short time period. Therefore, the budget constraint is not included in the short-term supply equation. It is more appropriate to be included in the time series model at the system level since the total budget is more variable in the long period of time.

In summary, there are four major factors that affect transit service supply in the short run: ridership in the previous planning year, ridership in the current quarter, policy headway requirements and land use patterns including population and employment. Major service changes occur once a year, and there are also on-going minor service and schedule changes corresponding to ridership shifts and service requests from passengers and communities. Since the ridership and service data used in this study are considered as average yearly data, the ridership and service changes 
can be considered as simultaneous. The transit supply equation is

$$
\begin{aligned}
\operatorname{LOS}_{i z} & =F\left(R_{i z}, R_{-1 i}, X_{i z}^{s}\right) \\
X^{s} & \in\{P O P, E M P D E N, H S C H\}
\end{aligned}
$$

Where,

$\mathrm{R}_{\mathrm{iz}}=$ the transit ridership at route $\mathrm{i}$ and zone $\mathrm{z}$ from equation (5.6).

$\operatorname{LOS}_{\mathrm{iz}}=$ the level of service represented by the total seats supplied, or the loading factor. It shows the service quantity supplied, and is defined by Equation (5.7).

$\mathbf{R}_{-1 \mathrm{i}}=$ the ridership of the route $\mathrm{i}$ in the previous planning year.

$\mathrm{X}^{\mathrm{s}}=\mathrm{A}$ subset of land use characteristics.

Other variables are defined as in Equation (5.6).

It should be noted that the policy headway is not included as an independent variable. It is part of the service supply included in the level of service variable (See Equation (5.4)). Because of the policy headway requirements, the independent variables in the supply equation may not explain all of the variations in the service supply.

\section{INTER-RELATIONSHIPS AMONG TRANSIT ROUTES}

Transit routes in a transit network are interdependent. This interdependent physical relationship among transit routes has been discussed and identified in Chapter 3. For physically related routes, a change of service and ridership in one route may have impacts on its related routes. However, the same physical relationship may have different possible ridership impacts. For example, a service increase on one the two 
routes that serve the same service areas may draw riders from the other route. It may also attract more riders from the service areas because of the total level of service increase in that area. The net effect of the service increase on one route may be a simple redistribution of current riders with little or no increase of total transit ridership, or a combination of redistribution and net increase of ridership. It is therefore necessary to discuss the service and ridership relationship among physically related routes, or inter-route effects.

Based on three inter-route physical linkages discussed in Chapter 3, there are four types of inter-route effects: indifference, complementary, competing and synergistic.

For independent and complementary routes, the inter-route effects are simple. For independent routes, there is no route overlap or ridership impacts. They are independent from each other, and can be treated independently in transit demand modeling.

For complementary routes, the service and ridership impact of one route upon the other is complementary. A service and ridership change in any of these routes will have a positive impact on the other routes. For example, a change of service frequency and its corresponding ridership change in a radial route will affect the ridership of its feeder routes, and vice verse.

For competing routes, however, the inter-route effect is more complicated. A service and ridership change in one route have two possible impacts on the other routes: competing and synergistic effects. 
Taking an example of two competing routes $\mathrm{A}$ and $\mathrm{B}$, assume the transit service frequency increases on route $\mathrm{A}$, some current riders in the common service area may shift to route $\mathrm{A}$ because a more frequent service reduces waiting time. As a result, the ridership on route A may increase while the ridership on route B may decrease. This negative ridership impact of service changes on the other routes, or the redistribution of current ridership among competing routes, is the competing effect.

A service increase on route A not only has an impact on current riders' route choice, but may also have an impact on potential riders in the common service areas. Because of the service increases on one route, the total transit service to the residents at the common service area increases, which may attract more transit users. The total ridership of these two routes may increase. This positive impact of service increase of one competing route on the other is the synergistic effect. The synergistic effect can be observed in some transit trunk lines where several bus routes share a common road, particularly on roads converging on the downtown area.

Both competing and synergistic effects are a function of how close the two competing routes are to each other. If two route buffers overlap only for a small portion, both competing effects and synergistic effects will be small. If two routes run very closely or even on the same road, a service change in one route will have a greater impact on the other. In other words, the competing and synergistic effects will become larger when two competing routes overlap in larger portions.

The final net ridership response of route $A$ and $B$ to the service change in route A will be determined by the combination of the competing effect and the synergistic 
effect. If the competing effect is dominant, current transit riders will shift from route B to $A$, the net effect of service changes in route $A$ is only a redistribution of current transit riders between route $A$ and $B$. If the synergistic effect is larger than the competing effect, ridership in route A will increase and ridership in route B will not decrease (it may even increase), so the net effect of service increase in route $\mathrm{A}$ will be a net increase of transit riders. Therefore, the final ridership changes in route $B$ corresponding to service changes in route A may decrease, increase or stay the same, depending on the magnitude of the difference between the competing and synergistic effects.

The inter-route relationship can be estimated by a simultaneous equation model. Ridership on the route of interest is modeled as a function of total ridership on the competing routes and complementary routes, as well as the service and demographic variables on the route of interest; the ridership of the complementary and competing routes is modeled as a function of ridership and services on the route of interest, the service and demographic data on the complementary and competing routes. These simultaneous equations are shown as follows:

$$
\begin{gathered}
R_{i z}=F\left(\text { SEATS }_{i z}, X_{i z}^{d}, \sum_{j} R_{j z}, \sum_{k} R_{k z}, \text { OVPOPPC }_{i j z}\right) \\
\sum_{k} R_{k z}=F\left(R_{i z}, \text { SEATS }_{i z z}, \sum_{k} F_{k Q_{k z}}, \sum_{k} X_{k z}^{d}\right) \\
\sum_{j} R_{j z}=F\left(\text { SEATS }_{i z}, \sum_{j} F_{j} Q_{j z}, \text { OVPOPPC }_{i j z}\right)
\end{gathered}
$$

Where, 
OVPOPPC $=$ The percentage of population in the overlap area of two competing route buffers over the total population on the competing routes. It is defined as in Equation (3.11). hour.

FRQ $=$ The frequency of transit service, expressed by the number of buses per

The subscript of $\mathrm{i}$ refers to the route of interest, $\mathrm{j}$ refers to the competing route of $\mathrm{i}$, and $\mathrm{k}$ is the complementary route. The subscript of $\mathrm{z}$ refers to the fare zone number, there are four fare zones in the Tri-Met service area, $z=0,1,2,3$.

Other variables are defined as in Equations (5.6), (5.7) and (5.8).

It should be noted that Equation (5.9) is a revision of equation (5.6), taking inter-route effects $\left(R_{j}\right.$ and $\left.R_{k}\right)$ into account.

In calibrating these simultaneous equations to estimate the inter-route effects, there will be a potential problem if complementary routes are the same for most routes of interests. For example, if crosstown routes intersect with most radial routes and are therefore considered as complementary routes for all radial routes, $\sum \mathrm{R}_{\mathrm{kz}}$ is a constant or has a very little variation among all radial routes, and this will cause problems in model calibration. This is exactly the case in this study area.

To solve this problem, an alternative has to be sought. This study uses alightings of the complementary routes at the route intersection points rather than the total ridership of the complementary routes to estimate the ridership on the route of interest in equation (5.9). $\sum R_{\mathrm{kz}}$ is now a summation of alightings at all intersection points from complementary routes for the route of interest $i$. By using alightings from complementary routes it eliminates the need to estimate the equation (5.10). The demand equation (5.9) now becomes: 


$$
R_{i z}=F\left(L_{i z}, X_{i z}{ }^{d}, \sum_{j} R_{j z}, \sum_{k} A \operatorname{LIGHT}_{k z}, \text { OVPOPPC }_{i j 2}\right)
$$

Where, $\sum_{k} A$ ILIGHT $_{k z}$ is the total alightings from complementary routes $k$ at the intersection points with route of interest $i$.

The limitation of eliminating equation (5.10) is that it only considers the influences of alightings from complementary routes on the route of interest, but it ignores the feedback effect of the alighting responses to service changes on the route of interest. It assumes that alighting changes in the complementary routes will have direct impact on the ridership on the route of interest, but the service changes on the route of interest have no impact on the alightings of complementary routes. This is a limitation of this model. Further study needs to take this feedback effect into account.

These simultaneous models will be estimated for five time periods (morning peak, mid-day, afternoon peak, evening, and night) and two directions (inbound and out bound). Different variables are used in different models because of different travel patterns and influencing factors discussed in Chapter 4 . These different variables are listed in Table 5.3 for demand and supply equations by different models.

\section{SUMMARY}

In summary, transit ridership on the route of interest is an interactive result of two simultaneous processes: the simultaneity of transit demand and supply, and the simultaneity of ridership on one route and its related routes. A service change on one route will have four impacts. The first impact is on the ridership on the route of service 
change. The second impact is on the ridership of the competing routes, ridership on the competing routes may decrease (or increase) if the service on the route of interest increases (or decreases), the riders can shift between the route of interest and its competing routes. The third impact is on the net effects of all ridership changes considering both the route of interest and its competing routes. And the final impact is that the ridership changes will influence further transit service supplies. 
TABLE 5.3. Determinant Variables for Demand and Supply Equations in Different Time Periods and Directions

\begin{tabular}{|c|c|c|c|}
\hline Direction & $\begin{array}{l}\text { Time } \\
\text { Periods }\end{array}$ & Demand Equation & Supply Equation \\
\hline \multirow{5}{*}{ Inbound } & $\begin{array}{l}\text { Morning } \\
\text { Peak }\end{array}$ & $\begin{array}{l}\text { Population, Income, High } \\
\text { school student, Park-and-ride } \\
\text { capacity, Service supplied, } \\
\text { Alightings from complementary } \\
\text { routes, Ridership on competing } \\
\text { routes, Route typology } \\
\text { dummy, Zone dummy }\end{array}$ & $\begin{array}{l}\text { Current ridership, } \\
\text { Ridership in } \\
\text { previous year, } \\
\text { Population, } \\
\text { Employment density, } \\
\text { Route typology } \\
\text { dummy }\end{array}$ \\
\hline & Mid-day & $\begin{array}{l}\text { Population, Income, High } \\
\text { school student, Park-and-ride } \\
\text { capacity, Service supplied, } \\
\text { Alighting from complementary } \\
\text { routes, Ridership on competing } \\
\text { routes, Route typology } \\
\text { dummy, Zone dummy }\end{array}$ & $\begin{array}{l}\text { Current ridership, } \\
\text { Ridership in } \\
\text { previous year, } \\
\text { Population, } \\
\text { Employment density, } \\
\text { Route typology } \\
\text { dummy }\end{array}$ \\
\hline & $\begin{array}{l}\text { Afternoon } \\
\text { Peak }\end{array}$ & $\begin{array}{l}\text { Population, Income, Service } \\
\text { supplied, Alighting from } \\
\text { complementary routes, } \\
\text { Ridership on competing routes, } \\
\text { Route typology dummy, Zone } \\
\text { dummy }\end{array}$ & $\begin{array}{l}\text { Current ridership, } \\
\text { Ridership in previous } \\
\text { year, Population, } \\
\text { Employment density, } \\
\text { Route typology } \\
\text { dummy }\end{array}$ \\
\hline & Evening & $\begin{array}{l}\text { Population, Income, Service } \\
\text { supplied, Alighting from } \\
\text { complementary routes, } \\
\text { Ridership on competing routes, } \\
\text { Route typology dummy, Zone } \\
\text { dummy }\end{array}$ & $\begin{array}{l}\text { Current ridership, } \\
\text { Ridership in } \\
\text { previous year, } \\
\text { Population, } \\
\text { Employment density, } \\
\text { Route typology } \\
\text { dummy }\end{array}$ \\
\hline & Night & $\begin{array}{l}\text { Population, Income, Services } \\
\text { supplied, On time } \\
\text { performance, Alighting from } \\
\text { complementary routes, } \\
\text { Ridership on competing routes, } \\
\text { Route typology dummy, Zone } \\
\text { dummy }\end{array}$ & $\begin{array}{l}\text { Current ridership, } \\
\text { Ridership in } \\
\text { previous year, } \\
\text { Population, } \\
\text { Employment density, } \\
\text { Route typology } \\
\text { dummy }\end{array}$ \\
\hline
\end{tabular}


TABLE 5.3. (Continued)

\begin{tabular}{|c|c|c|c|}
\hline \multirow{5}{*}{ Outbound } & $\begin{array}{l}\text { Morning } \\
\text { Peak }\end{array}$ & $\begin{array}{l}\text { Population, Income, High } \\
\text { school student, Services } \\
\text { supplied, Alighting from } \\
\text { complementary routes, } \\
\text { Ridership on competing routes, } \\
\text { Route typology dummy, Zone } \\
\text { dummy }\end{array}$ & $\begin{array}{l}\text { Current ridership, } \\
\text { Ridership in } \\
\text { previous year, } \\
\text { Population, High } \\
\text { school student, } \\
\text { Route typology } \\
\text { dummy }\end{array}$ \\
\hline & Mid-day & $\begin{array}{l}\text { Population, Population density, } \\
\text { Income, High school students, } \\
\text { Services supplied, Alighting } \\
\text { from complementary routes, } \\
\text { Ridership on competing routes, } \\
\text { Route typology dummy, Zone } \\
\text { dummy }\end{array}$ & $\begin{array}{l}\text { Current ridership, } \\
\text { Ridership in } \\
\text { previous year, } \\
\text { Population, High } \\
\text { school student, } \\
\text { Route typology } \\
\text { dummy }\end{array}$ \\
\hline & $\begin{array}{l}\text { Afternoon } \\
\text { Peak }\end{array}$ & $\begin{array}{l}\text { Population downstream, } \\
\text { Employment density, Services } \\
\text { supplied, Alighting from } \\
\text { complementary routes, } \\
\text { Ridership on competing routes, } \\
\text { Route typology dummy, Zone } \\
\text { dummy }\end{array}$ & $\begin{array}{l}\text { Current ridership, } \\
\text { Ridership in } \\
\text { previous year, } \\
\text { Population, Route } \\
\text { typology dummy }\end{array}$ \\
\hline & Evening & $\begin{array}{l}\text { Population downstream, } \\
\text { Population, Income, } \\
\text { Employment density, Services } \\
\text { supplied, Alighting from } \\
\text { complementary routes, } \\
\text { Ridership on competing routes, } \\
\text { Route typology dummy, Zone } \\
\text { dummy } \\
\end{array}$ & $\begin{array}{l}\text { Current ridership, } \\
\text { Ridership in } \\
\text { previous year, } \\
\text { Population, Route } \\
\text { typology dummy }\end{array}$ \\
\hline & Night & $\begin{array}{l}\text { Population downstream, } \\
\text { Population, Income, } \\
\text { Employment density, Services } \\
\text { supplied, Alighting from } \\
\text { complementary routes, } \\
\text { Ridership on competing routes, } \\
\text { Route typology dummy, Zone } \\
\text { dummy }\end{array}$ & $\begin{array}{l}\text { Current ridership, } \\
\text { Ridership in } \\
\text { previous year, } \\
\text { Population, Route } \\
\text { typology dummy }\end{array}$ \\
\hline
\end{tabular}




\section{CHAPTER 6}

\section{MODEL ESTIMATION}

The combination of the demand equation, supply equation, and equations for competing routes forms a whole simultaneous system model. For convenience, those equations illustrated in Chapter 5 (Equations (5.12), (5.8) and (5.11)) are restated as follows:

$$
\begin{aligned}
& R_{i z}=F\left(\text { LOS }_{i z}, \sum_{j} R_{j z}, \sum_{k} \text { ALIGHT }_{k z}, X_{i z}^{d}, \text { OVPOPPC }_{i j z}\right) \\
& \mathrm{X}^{\mathrm{d}} \in\{\text { POP, INC, EMPDEN, PARK, HSCH }\} \\
& \operatorname{LOS}_{i z}=F\left(R_{i z}, R_{-1 i}, X_{i z}^{s}\right) \\
& \mathrm{X}^{\mathrm{s}} \in\{\mathrm{POP}, \mathrm{EMPDEN}, \mathrm{HSCH}\} \\
& \sum_{j} R_{j z}=F\left(\operatorname{LOS}_{i z}, \sum_{j} F R Q_{j z}, \text { OVPOPPC }_{i j z}\right)
\end{aligned}
$$

The definitions of these variables are shown in Chapter 5 .

Several functional forms of this simultaneous system model have been tested. The linear model seems to perform better in terms of goodness of fit and the significance of variables. Other function forms tested include logarithmic form and logarithm-linear form. The advantage of the logarithmic form is that coefficients can be directly used as constant elasticities. However, the logarithmic form cannot be used 
if the elasticity of an independent variable is not constant. Furthermore, the zero value of observations cannot be transformed to the logarithmic value. The linear form does not need data transformation, it is straightforward in interpretation, but the problem of the linear model is that the estimated value of the dependent variables could become negative, which is hard to interpret intuitively.

The system model is calibrated for five time periods (morning peak, mid-day, afternoon peak, evening and night period) in two directions (inbound and outbound direction). Therefore ten models are estimated altogether. Different variables are used in different models because of the different travel patterns and influencing factors as discussed in Chapters 4 and 5.

The calibration results of these ten models using three stage least square (3SLS) estimation method are shown in Tables 6.1-6.6. Tables 6.1-6.3 are models for the inbound direction while Tables 6.4-6.6 are models for the outbound direction. The following sections discusses the calibration results in more detail.

\section{MODELS FOR INBOUND DIRECTION}

The common characteristic of inbound routes is that most rides are from places of residence and transit service is planned to facilitate trips from home to work. The characteristics of the residents and residential land use patterns are important factors that influence boarding rides.

The coefficients in the individual equation represent the initial impact of variable changes upon the dependent variables. But the total impact must take the other 
equations into consideration. For example, to find out the total impact of level of service on the ridership, it not only needs to consider the coefficient of service variable in the demand equation, it must also consider the feedback effects from the supply equation and the equation for competing routes. Furthermore, to measure the total impact of exogenous variables upon three endogenous variables, the coefficients must be calculated from the reduced form equations. The initial impact, represented by the coefficients in the demand equations, is analyzed first in this section. The total impact will be discussed in the Section III of this chapter.

\section{Demand Equations}

The most important independent variables that affect inbound ridership are level of service, population, income, large park-and-ride lot capacity provided by Tri-Met, and fare zone dummy variables. Ridership on complementary routes and competing routes, and route typology dummy variables are less important. High school student enrollment, small park-and-ride lots provided by participated churches, are not significant in all time periods and are dropped from the final models in both inbound and outbound directions.

The level of service (LOS), represented by total seats provided at each time period, is highly significant in all time periods. The coefficients of $\operatorname{LOS}_{\mathrm{iz}}$ (Table 6.1) show that the transit service increase generates the highest initial boarding rides during the morning peak and mid-day periods. One hundred more seats can generate about 29 more rides in the morning peak hours and 31 rides in the mid-day period from each 
TABLE 6.1 Demand Equations for Inbound Direction

\begin{tabular}{|c|c|c|c|c|c|}
\hline Independent Variables & AM Peak & Mid-day & PM Peak & Evening & Night \\
\hline $\begin{array}{l}\text { Total Seat Supply } \\
\left(\operatorname{LOS}_{\text {iz }}\right)\end{array}$ & $\begin{array}{l}0.289 * * * \\
(7.892) \\
\end{array}$ & $\begin{array}{l}0.312 * * * \\
(11.09)\end{array}$ & $\begin{array}{l}0.220 * * * \\
(9.351)\end{array}$ & \begin{tabular}{|l}
$0.185 * * *$ \\
$(8.569)$ \\
\end{tabular} & $\begin{array}{l}0.223 * * * \\
(6.457) \\
\end{array}$ \\
\hline Population $\left(\mathrm{POP}_{\mathrm{i}}\right)$ & $\begin{array}{l}0.0134 * * * \\
(4.687) \\
\end{array}$ & $\begin{array}{l}0.017 * * * \\
(3.704) \\
\end{array}$ & $\begin{array}{l}0.0049 * * * \\
(2.960) \\
\end{array}$ & \begin{tabular}{|l}
$0.0025 * * *$ \\
$(2.677)$ \\
\end{tabular} & \begin{tabular}{|l}
$0.0062 * * *$ \\
$(2.489)$ \\
\end{tabular} \\
\hline $\begin{array}{l}\text { Household with income } \\
\text { less than } \$ 25,000 \\
\text { (INCLS25B } \mathrm{B}_{\mathrm{i}} \text { ) }\end{array}$ & $\begin{array}{l}0.015 \\
(1.211)\end{array}$ & $\begin{array}{l}0.051 * * * \\
(2.765)\end{array}$ & $\begin{array}{l}0.018 * * * \\
(2.504)\end{array}$ & $\begin{array}{l}0.0087 * * * \\
(2.197)\end{array}$ & $\begin{array}{l}0.012 \\
(1.094)\end{array}$ \\
\hline $\begin{array}{l}\text { Tri-Met Park-and-ride } \\
\text { lot capacity }\left(\text { PARKTRI } \mathrm{I}_{\mathrm{i}} \text { ) }\right.\end{array}$ & $\begin{array}{l}0.516 * * * \\
(9.627) \\
\end{array}$ & $\begin{array}{l}0.403 * * * \\
(5.173) \\
\end{array}$ & & & $\begin{array}{l}0.455 * * * \\
(10.93) \\
\end{array}$ \\
\hline $\begin{array}{l}\text { Total alighting from } \\
\text { complementary routes } \\
\left(\sum \text { ALIGHT }_{k 2}\right)\end{array}$ & $\begin{array}{l}0.189 * * * \\
(2.00)\end{array}$ & $\begin{array}{l}0.106 \\
(1.45)\end{array}$ & $\begin{array}{l}0.105 \\
(1.362)\end{array}$ & $\begin{array}{l}0.171 * * * \\
(2.021)\end{array}$ & $\begin{array}{l}0.090 \\
(0.666)\end{array}$ \\
\hline $\begin{array}{l}\text { Total Rides on } \\
\text { competing routes } \\
\left(\sum \mathrm{R}_{\mathrm{j}}\right){ }^{*} \mathrm{OVPOPPC}_{\mathrm{ij} 2} \\
\end{array}$ & $\begin{array}{l}-0.197 * * * \\
(-2.416)\end{array}$ & $\begin{array}{l}-0.042 \\
(-0.996)\end{array}$ & $\begin{array}{l}-0.053 \\
(-0.898)\end{array}$ & $\begin{array}{l}-0.146 \\
(-1.477)\end{array}$ & $\begin{array}{l}-0.0107 \\
(-0.750)\end{array}$ \\
\hline $\begin{array}{l}\text { Crosstown route dummy } \\
\text { (CROSTWND })\end{array}$ & $\begin{array}{l}-1.355 \\
(-0.034) \\
\end{array}$ & $\begin{array}{l}-88.969 \\
(-1.529)\end{array}$ & & $\begin{array}{l}-22.39 * * \\
(-1.863) \\
\end{array}$ & $\begin{array}{l}-83.16 * * * \\
(-2.33) \\
\end{array}$ \\
\hline $\begin{array}{l}\text { Feeder route dummy } \\
\left(\text { FEEDERD }_{i}\right)\end{array}$ & $\begin{array}{l}-66.34 * * \\
(-1.844) \\
\end{array}$ & $\begin{array}{l}-92.24 \\
(-1.561) \\
\end{array}$ & $\begin{array}{l}-45.27 * * * \\
(-2.262) \\
\end{array}$ & \begin{tabular}{|l|}
$-33.84 * * *$ \\
$(-2.824)$ \\
\end{tabular} & $\begin{array}{l}-37.812 \\
(-1.047) \\
\end{array}$ \\
\hline Fare zone 1 dummy & $\begin{array}{l}120.51 * * * \\
(4.612) \\
\end{array}$ & $\begin{array}{l}64.40 * * * \\
(4.385) \\
\end{array}$ & $\begin{array}{l}44.273 * * * \\
(3.144) \\
\end{array}$ & \begin{tabular}{|l}
$22.095 * * *$ \\
$(3.02)$ \\
\end{tabular} & \begin{tabular}{|l}
$47.276 * * *$ \\
$(2.04)$
\end{tabular} \\
\hline fare zone 2 dummy & $\begin{array}{l}146.00 * * * \\
(4.85) \\
\end{array}$ & $\begin{array}{l}170.89 * * * \\
(3.748) \\
\end{array}$ & $\begin{array}{l}34.268 * * * \\
(1.979)\end{array}$ & $\begin{array}{l}27.154 * * * \\
(3.004) \\
\end{array}$ & \begin{tabular}{|l}
$68.77^{* * *}$ \\
$(2.561)$ \\
\end{tabular} \\
\hline fare zone 3 dummy & $\begin{array}{l}-2.821 \\
(-0.08) \\
\end{array}$ & $\begin{array}{l}17.519 \\
(0.336) \\
\end{array}$ & $\begin{array}{l}11.274 \\
(0.568) \\
\end{array}$ & $\begin{array}{l}13.095 \\
(1.342) \\
\end{array}$ & \begin{tabular}{|l}
24.867 \\
$(0.865)$ \\
\end{tabular} \\
\hline Constant & $\begin{array}{l}-188.79 \\
(-6.41)^{* * *} \\
\end{array}$ & $\begin{array}{l}-409.14 \\
(-8.95)^{* * *} \\
\end{array}$ & $\begin{array}{l}-105.61 \\
(-5.76)^{* * *}\end{array}$ & $\begin{array}{l}-65.709 \\
(-6.95)^{* * *} \\
\end{array}$ & $\begin{array}{l}-126.65 \\
(-5.03)^{* * *} \\
\end{array}$ \\
\hline$R^{2}$ & 0.76 & 0.73 & 0.64 & 060 & 0.74 \\
\hline Mean of Dependent & 129.96 & 225.86 & 72.88 & 31.61 & 97.41 \\
\hline & 183 & 175 & 173 & 171 & 162 \\
\hline
\end{tabular}

Numbers in Parentheses are calculated $t$ statistics.

*** Significant at the five percent level;

** Significant at the ten percent level. 
fare zone. While the same amount of service generates less ridership in other time periods. An 100 seats produces about 22 rides in the afternoon peak and night period, 19 rides in the evening. It should be noted that these ridership generating rates are for each fare zone, the total ridership for the whole line should be the summation of ridership in every fare zone the bus route goes through.

Population in the transit service area is significant in all time periods. It indicates that the number of persons in the service area determines inbound demand, and that most inbound riders board transit from places of residence. The coefficients of the population at different time periods cannot be directly compared, since the service hours for different time periods are different. To make them comparable, these coefficients have to be transformed into hourly basis, i.e., the coefficients for each time period need to be divided by the number of hours of service.

The transformed hourly coefficients are shown in Table 6.1a. The coefficients for the population on the hourly basis are the largest in the morning peak period, and decrease as the time approaches the evening period (Table 6.1a). An 1000 more persons can generate 6.5 more boarding rides per hour in the morning peak hours, 2.4 rides per hour in the mid-day and afternoon peak periods, 1.25 rides per hour in the evening period, and 1.55 rides per hour at night. This is the inbound model, the trip generating rate for afternoon peak period is lower than the morning peak. One should be cautious to use the hourly coefficients in the night period, because different routes have different hours of operation during that time period. An average of four hours is used here to calculate the hourly coefficients for the night time period. Because the 
night period includes early morning trips, the trip generating rate is higher at night than in the evening.

TABLE 6.1a Coefficients for Population in Inbound Demand Models

\begin{tabular}{||l|r|r|r|r|l||}
\hline & AM Peak & Mid-day & PM Peak & Evening & Night \\
\hline $\begin{array}{l}\text { Coefficients for } \\
\text { Total Population }\end{array}$ & 0.0134 & 0.017 & 0.0049 & 0.0025 & 0.0062 \\
\hline $\begin{array}{l}\text { Hourly Coefficients } \\
\text { of Population }\end{array}$ & 0.0067 & 0.0024 & 0.00245 & 0.00125 & 0.00155 \\
\hline
\end{tabular}

The income variable, represented by the number of households with income less than $\$ 25,000$, is highly significant in the mid-day, afternoon peak and evening period, but not significant in the morning peak and night period. This indicates that the peak commuting riders are more choice riders, while off-peak riders are more likely to be captive riders with low income. Transit riders at night are a combination of late evening and early morning riders, late evening riders are more transit dependent while early morning riders are morning commuter riders, the mixture of these two kinds of riders may be the cause of not being statistically significant.

Park-and-ride lots are divided into two categories: large park-and-ride lots provided by Tri-Met (PARKTRI) and small park-and-ride lots shared with participated churches. These two kinds of park-and-ride lots have different usage rates: Tri-Met lots are heavily used while the church lots are used less intensively, but the data for parking lot usage are not available. The lack of usage data creates the need to stratify the parkand-ride lots. The model results show that Tri-Met park-and-ride lots are significant 
while the church lots are not significant in explaining variations of transit ridership. The church lots are not included in the final model.

Alightings from the complementary routes contribute positively to the ridership on the routes of interest, indicating there are some transfers between complementary routes and routes of interest. The coefficients of the ridership on competing routes is negative, showing the more ridership on the competing routes, the less ridership on the route of interest. Both variables have the expected sign and are significant in the morning peak period, but are not highly significant in other time periods.

Transit demand is significantly different for different fare zones after controlling for other variables. Fare zone 2 has the most ridership, fare zone 1 comes the second, while fare zone 3 has the least. This is consistent with what is expected. People living in fare zones 1 and 2 are closer to the major employment center (downtown), and are relatively well served. Furthermore, by self-selection residents who chose to live in these inner cities are more pro-transit than those who live in the suburbs. All these factors contribute to significantly more transit ridership in fare zones 1 and 2 than in fare zone 3 . Since these are models for inbound routes, and most riders travel to downtown Portland, the number of boarding rides in the fareless square (fare zone 0 ) is significantly less than in fare zones 1 and 2 .

Most Tri-Met park-and-ride lots are located in fare zone 3. After controlling for parking lot capacity and other variables, the coefficient of the fare zone 3 dummy is negative for the morning peak and mid-day periods, the two periods that have parking lot variables. Coefficients of fare zone 3 in other time periods, without considering 
park-and-ride lots, are positive but are still less than those of fare zones 1 and 2.

Transit ridership is less on crosstown and feeder bus routes after controlling for other variables. Other radial route types (city radial, suburban radial, regional trunk, etc.) were also tested as dummy variables, but were found to be not significant. They are grouped into one category -- radial routes and are treated as a base.

The goodness of fit for demand equations is satisfactory. The $R^{2}$ at different time periods ranges from 0.60 to 0.75 , with the highest in the morning peak period, and the lowest in the evening period.

\section{Supply Equations}

Transit supply is affected by four important variables at the route level: ridership in the previous planning year, ridership at the current planning period, total population in the transit service area, and employment density.

Ridership in the previous planning year (1989) is highly significant in explaining transit service supply across all time periods. Ridership in 1989 is the total ridership for the entire route by different time periods, because it is not available at the fare zone level. Based on the ridership in 1989 alone, the most inbound service is provided in the morning peak and evening period, and the least in the midday and afternoon peak period. One hundred rides in 1989 at a whole route are provided about 50 seats at each zone in the morning peak and evening periods (Table 6.2), and about 31, 29 and 46 seats in the mid-day, afternoon peak and night period.

Current ridership at each fare zone is highly significant in explaining inbound 
service supply in the morning peak, mid-day and afternoon peak period. It is not significant in the evening and night periods (Table 6.2). This indicates that the service supply in the peak hours and mid-day period is responsive to current demand, while service supply in the evening and night periods is based on the policy headways and is not responsive to the current ridership. The bigger coefficients in the afternoon peak and evening period represent service supply in those time periods in the inbound direction is mainly returning buses after taking worker home, inbound ridership at these two time periods is smaller than in the morning peak and mid-day periods.

Taking both ridership in 1989 and current ridership into account, it can be shown that for the same amount of transit ridership, different levels of service is provided in different time periods. More service per ride is provided in the mid-day, afternoon peak and evening period than in the morning peak periods in the inbound direction. This shows the effect of the policy headway in the off-peak periods and returning trips in the afternoon peak period.

Inbound transit service supply is also driven by the employment density. Employment density is significant in all time periods. The coefficients among different time periods can not be directly compared with each other because of the variations of service hours in different time periods. After being transformed into the hourly basis, coefficients of the employment density become $0.17,0.08,0.13$ and 0.08 in the morning peak, mid-day, afternoon peak and evening period, respectively. In other words, one hundred employees per acre are provided 17 seats per hour in the morning peak period and 8 seats per hour in the mid-day and evening period, while 13 seats per 
hour are provided in the afternoon peak period. It should be noted, however, the employment is a total daily number. Employment by different time period of a day is not available.

TABLE 6.2 Supply Equations for Inbound Direction

\begin{tabular}{|c|c|c|c|c|c|}
\hline \multicolumn{6}{|c|}{ Dependent Variable $=$ Total Seats $\left(\operatorname{LOS}_{\mathrm{iz}}\right)$} \\
\hline Independent Variables & AM Peak & Mid-day & PM Peak & Evening & Night \\
\hline $\begin{array}{l}\text { Ridership at Current } \\
\text { Planning Period }\left(\mathrm{R}_{\mathrm{iz}}\right)\end{array}$ & $\begin{array}{l}0.162^{* * *} \\
(2.059)\end{array}$ & $\begin{array}{l}0.493 * * * \\
(2.472)\end{array}$ & $\begin{array}{l}0.619 * * * \\
(2.004)\end{array}$ & $\begin{array}{l}0.688 \\
(1.56)\end{array}$ & $\begin{array}{l}0.167 \\
(0.869)\end{array}$ \\
\hline $\begin{array}{l}\text { Ridership in } 1989 \\
\left(\mathrm{R} 89_{\mathrm{i}}\right)\end{array}$ & $\begin{array}{l}0.505^{* * *} \\
(18.95) \\
\end{array}$ & $\begin{array}{l}0.311^{* * *} \\
(9.509) \\
\end{array}$ & $\begin{array}{l}0.286 * * * \\
(10.00)\end{array}$ & $\begin{array}{l}0.491 * * * \\
(7.933)\end{array}$ & $\begin{array}{l}0.464 * * * \\
(10.22)\end{array}$ \\
\hline Population ( $\mathrm{POP}_{\mathrm{iz}}$ ) & $\begin{array}{l}-0.0047 * * * \\
(-2.982)\end{array}$ & $\begin{array}{l}-0.022 * * * \\
(-3.755)\end{array}$ & $\begin{array}{l}-0.0072 * * * \\
(-2.889)\end{array}$ & $\begin{array}{l}-0.0048 * * * \\
(-2.547)\end{array}$ & $\begin{array}{l}-0.0017 \\
(-0.358)\end{array}$ \\
\hline $\begin{array}{l}\text { Employment Density } \\
\left(\text { EMPDEN }_{i z}\right)\end{array}$ & $\begin{array}{l}0.344 * * * \\
(3.105) \\
\end{array}$ & $\begin{array}{l}0.584^{* * *} \\
(2.082) \\
\end{array}$ & $\begin{array}{l}0.259 * * * \\
(2.42) \\
\end{array}$ & $\begin{array}{l}0.161 * * \\
(1.916) \\
\end{array}$ & \\
\hline $\begin{array}{l}\text { Crosstown Dummy } \\
\left.\text { (CROSTWND })_{i}\right)\end{array}$ & $\begin{array}{l}-127.37 * * * \\
(-4.763)\end{array}$ & $\begin{array}{l}29.802 \\
(0.378)\end{array}$ & & $\begin{array}{l}37.668 * * * \\
(1.984)\end{array}$ & $\begin{array}{l}-35.266 \\
(-0.598)\end{array}$ \\
\hline $\begin{array}{l}\text { Feeder Route Dummy } \\
\left(\text { FEEDERD }_{\mathrm{i}}\right)^{2}\end{array}$ & $\begin{array}{l}93.736 * * * \\
(3.518)\end{array}$ & $\begin{array}{l}173.35 * * * \\
(2.173)\end{array}$ & $\begin{array}{l}71.566 * * * \\
(2.481)\end{array}$ & $\begin{array}{l}52.039 * * * \\
(2.436)\end{array}$ & $\begin{array}{l}-13.867 \\
(-0.218)\end{array}$ \\
\hline Constant & $\begin{array}{l}131.52 * * * \\
(7.959)\end{array}$ & $\begin{array}{l}470.55 * * * \\
(8.584) \\
\end{array}$ & $\begin{array}{l}169.59 * * * \\
(8.586)\end{array}$ & $\begin{array}{l}143.20 * * * \\
(9.651)\end{array}$ & $\begin{array}{l}162.8^{* * *} \\
(4.606)\end{array}$ \\
\hline $\mathrm{R}^{2}$ & 0.88 & 0.77 & 0.83 & 0.81 & 0.62 \\
\hline $\begin{array}{l}\text { Mean of Dependent } \\
\text { Variable }\end{array}$ & 367.24 & 885.95 & 332.37 & 241.29 & 444.71 \\
\hline
\end{tabular}

Numbers in Parentheses are calculated $t$ statistics.

*** Significant at the five percent level;

** Significant at the ten percent level.

It is interesting to note that coefficients for population are consistently negative across all time periods and statistically significant. This can be mostly explained by the fact that Tri-Met is under great political pressure to provide service to a broader area. 
The broad area coverage cause transit service to extend to low density suburban areas. Those areas have less population inside the transit service areas, but the transit service is no less than in the urban areas because of the policy to run all buses the entire length of a route. Therefore, by controlling for the ridership, there exists a negative relationship between population and service supply.

The route typology also contributes to the transit service supply. The coefficients for feeder bus routes are significant and positive, that indicates that after controlling for ridership and other variables, feeder bus routes have more service than the radial routes. This implies that service is over-supplied for feeder bus routes. The coefficient for the crosstown route dummy variable is negative in the morning peak and night periods and positive in other time periods, indicating the crosstown routes are under-supplied in the morning peak period and over-supplied in other time periods after controlling for ridership and other variables.

The overall goodness of fit of the supply equations is better than the demand equations. The $\mathrm{R}^{2} \mathrm{~s}$ are above 0.77 for the morning, midday, afternoon and evening periods, ranges from 0.88 in the morning to 0.77 in the mid-day. But the $R^{2}$ is lower for the night model, it is only 0.62 .

\section{Equations for Competing Routes}

The equations for competing routes are used to describe how the ridership on competing routes responds to service changes on the routes of interest. Three variables are included to explain the variations of the ridership on the competing routes: service 
frequency on competing routes, the product of the level of service (seats) on the route of interest and the percentage of population in the overlap areas between the route of interest and its competing routes, the number of population in the overlap areas, and the total population on the competing routes (Table 6.3).

The frequency on competing routes is the total number of buses per hour on the competing routes. It is positive and highly significant in all time periods. The major reason for using total frequency is that more frequent service reduces average waiting time. It is the transit frequency that affect riders' choice of choosing one route over the other if the vehicle is not over-crowded, which is usually the case on most transit routes in most of time periods.

The coefficients of the service supply on the route of interest are negative. If more service is supplied on the route of interest, it may attract some riders from its competing routes, which cause less ridership on the competing routes. The coefficients are adjusted by the strength of the relationship between two competing routes, which is represented by the percentage of population in the overlap areas. The stronger the relationship (the larger value of population percentage in the overlap area) between two competing routes, the larger impact (or the larger absolute value of the coefficients) of the service of the subject routes on the competing routes.

As is expected, the coefficients of population on the competing routes are positive, while the coefficients of population on the overlap areas are negative, both variables are highly significant across all time periods. The variable of population on the competing routes takes into account the double counting of population served by 
more than one transit route. The negative sign of the coefficients shows this double counting effect. It indicates that the larger population in the overlap area the smaller the ridership on the competing routes, because a large overlap area offers more residents a choice among competing routes.

The $R^{2}$ for the equations of competing routes ranges from 0.61 to 0.75 . Given only four variables, the goodness of fit is quite good. In addition, this equation is used to assist estimating ridership on the route of interest and the net effect of service changes. A small $\mathrm{R}^{2}$ is not a big concern.

TABLE 6.3 Equations for Competing Routes for Inbound Direction

\begin{tabular}{|c|c|c|c|c|c|}
\hline \multicolumn{6}{|c|}{ Dependent Variable $=$ Total Ridership on Competing Routes $\left(\mathrm{R}_{\mathrm{j} 2}\right)$} \\
\hline Independent Variables & AM Peak & Mid-day & PM Peak & Evening & Night \\
\hline $\begin{array}{l}\text { Frequency on } \\
\text { Competing Routes } \\
\left(\text { FRQ }_{\mathrm{j} 2}\right)\end{array}$ & $\begin{array}{l}8.692 * * * \\
(3.034)\end{array}$ & $\begin{array}{l}43.157 * * * \\
(7.391)\end{array}$ & $\begin{array}{l}9.965 * * * \\
(6.929)\end{array}$ & $\begin{array}{l}4.945 * * * \\
(3.845)\end{array}$ & $\begin{array}{l}11.299 * * * \\
(2.315)\end{array}$ \\
\hline $\operatorname{LOS}_{\mathrm{iz}} * \mathrm{OVPOPPC}_{\mathrm{ijz}}$ & $\begin{array}{l}-0.182 \\
(-1.272) \\
\end{array}$ & $\begin{array}{l}-0.098 \\
(-1.068) \\
\end{array}$ & $\begin{array}{l}-0.025 \\
(-0.599) \\
\end{array}$ & $\begin{array}{l}-0.038 \\
(-0.344) \\
\end{array}$ & $\begin{array}{l}0.075 \\
(0.623) \\
\end{array}$ \\
\hline $\begin{array}{l}\text { Population in the } \\
\left.\text { Overlap Area } \text { (OVPOPPC }_{\mathrm{ij} 2}\right)\end{array}$ & $\begin{array}{l}-0.019 * * * \\
(-7.918)\end{array}$ & $\begin{array}{l}-0.026 * * * \\
(-7.695)\end{array}$ & $\begin{array}{l}-0.0066 * * \\
(-6.87)\end{array}$ & $\begin{array}{l}-0.0043 * * \\
(-6.076)\end{array}$ & $\begin{array}{l}-0.014 * * * \\
(-9.998)\end{array}$ \\
\hline $\begin{array}{l}\text { Population on the } \\
\text { Competing Routes } \\
\left(\mathrm{POP}_{\mathrm{j} z}\right)\end{array}$ & $\begin{array}{l}0.0181 * * * \\
(14.51)\end{array}$ & $\begin{array}{l}0.022 * * * \\
(11.78)\end{array}$ & $\begin{array}{l}0.0060 * * * \\
(12.26)\end{array}$ & $\begin{array}{l}0.0037 * * * \\
(9.739)\end{array}$ & $\begin{array}{l}0.012 * * * \\
(12.82)\end{array}$ \\
\hline Constant & $\begin{array}{l}31.347 \\
(0.774) \\
\end{array}$ & $\begin{array}{l}36.813 \\
(0.639) \\
\end{array}$ & $\begin{array}{l}21.14 \\
(0.946) \\
\end{array}$ & $\begin{array}{l}3.82 \\
(0.275) \\
\end{array}$ & $\begin{array}{l}-1.523 \\
(-0.057) \\
\end{array}$ \\
\hline $\mathrm{R}^{2}$ & 0.65 & 0.67 & 0.66 & 0.61 & 0.75 \\
\hline
\end{tabular}

Numbers in Parentheses are calculated t statistics;

*** Significant at the five percent level;

** Significant at the ten percent level. 


\section{MODELS FOR THE OUTBOUND DIRECTION}

The common characteristics of outbound routes are that most transit riders are from places of employment and transit service is provided to facilitate trips from work places to home. The characteristics of employment and non-residential land use patterns are important factors that influence boarding rides for the outbound direction.

Like the discussion of inbound models in Section I, this section only analyzes the initial impact of variables from the individual equations, it does not take into account the feedback effects from other equations.

\section{Demand Equations}

The major variables that affect transit demand in the outbound direction are service quantity, employment density, population downstream, income, and alightings from complementary routes. The model for the morning peak period has a different structure from the other time periods, because in the morning peak period, outbound transit trips are home-to-work. It is the characteristics of the place of residence that affects boarding rides. Therefore, the employment density and population downstream, two variables that affect boarding rides at the place of employment, cannot be used in the outbound model for the morning peak period.

The level of service variable is positive and significant across all time periods. The coefficients are the largest for the afternoon peak and mid-day periods, while the evening, night and morning peak models have smaller coefficients (Table 6.4). One hundred more seats can generate about 33, 27 and 23 initial rides in each fare zone in 
TABLE 6.4 Demand Equations for Outbound Direction

\begin{tabular}{|c|c|c|c|c|c|}
\hline \multicolumn{6}{|c|}{ Dependent Variable $=$ Boarding Riders $\left(\mathrm{R}_{\mathrm{i}}\right)$} \\
\hline Ind. Variables & AM Peak & Mid-day & PM Peak & Evening & Night \\
\hline $\begin{array}{l}\text { Total seats supply } \\
\text { (LOS }{ }_{\mathrm{iz}} \text { ) }\end{array}$ & $\begin{array}{l}0.164 * * * \\
(7.908)\end{array}$ & $\begin{array}{l}0.272 * * * \\
(9.195)\end{array}$ & $\begin{array}{l}\begin{array}{l}0.332 * * * \\
(6.376)\end{array} \\
\end{array}$ & $\begin{array}{l}0.226 * * * \\
(11.19)\end{array}$ & $\begin{array}{l}0.161 * * * \\
(7.981)\end{array}$ \\
\hline $\begin{array}{l}\text { Employment Density } \\
\left(\text { EMPDEN }_{i}\right)\end{array}$ & & $\begin{array}{l}2.342 * * * \\
(10.89) \\
\end{array}$ & $\begin{array}{l}2.616 * * * \\
(11.97) \\
\end{array}$ & $\begin{array}{l}0.589 * * * \\
(11.16)\end{array}$ & $\begin{array}{l}0.721 * * * \\
(9.734) \\
\end{array}$ \\
\hline $\begin{array}{l}\text { Population } \\
\text { Downstream } \\
\left.\text { POPDWN }_{\mathrm{i}}\right)\end{array}$ & & $\begin{array}{l}0.0035 * * * \\
(2.626)\end{array}$ & $\begin{array}{l}0.0052 * * * \\
(5.471)\end{array}$ & $\begin{array}{l}0.00066 * * \\
(2.236)\end{array}$ & $\begin{array}{l}0.00055 \\
(1.185)\end{array}$ \\
\hline $\begin{array}{l}\text { Population } \\
\left(\text { (POPBF }_{i}\right)\end{array}$ & $\begin{array}{l}0.00525 * * * \\
(3.812)\end{array}$ & & & & \\
\hline $\begin{array}{l}\text { Households with } \\
\text { income less than } \\
\$ 25,000 \\
\left(\text { INCLS } 25 B_{i z}\right)\end{array}$ & $\begin{array}{l}0.0056 \\
(0.957)\end{array}$ & $\begin{array}{l}0.061 * * * \\
(6.599)\end{array}$ & & $\begin{array}{l}0.0099 * * * \\
(4.746)\end{array}$ & $\begin{array}{l}0.016 * * * \\
(4.925)\end{array}$ \\
\hline $\begin{array}{l}\text { Total alighting from } \\
\text { complementary } \\
\text { routes }\left(\sum \text { ALIGHT }_{k} \text { ) }\right.\end{array}$ & $\begin{array}{l}0.191 * * * \\
(2.673)\end{array}$ & $\begin{array}{l}0.166 * * * \\
(2.632)\end{array}$ & $\begin{array}{l}0.148 * * * \\
(3.276)\end{array}$ & $\begin{array}{l}0.039 \\
(0.942)\end{array}$ & $\begin{array}{l}0.0664 \\
(0.988)\end{array}$ \\
\hline $\begin{array}{l}\text { Total ridership on } \\
\text { competing routes } \\
\left(\sum \mathrm{R}_{\mathrm{j} 2}\right)^{*} \text { OVPOPPC }\end{array}$ & $\begin{array}{l}-0.016 \\
(-0.503)\end{array}$ & $\begin{array}{l}-0.041 * * * \\
(-2.468)\end{array}$ & $\begin{array}{l}-0.135 * * * \\
(-5.81)\end{array}$ & $\begin{array}{l}-0.079 * * * \\
(-3.819)\end{array}$ & $\begin{array}{l}-0.0409 * * \\
(-1.83)\end{array}$ \\
\hline $\begin{array}{l}\text { Crosstown Dummy } \\
\text { (CROSTWND) }\end{array}$ & & $\begin{array}{r}76.067 \\
(1.317) \\
\end{array}$ & $\begin{array}{l}167.29 * * * \\
(3.513) \\
\end{array}$ & $\begin{array}{l}20.485 \\
(1.618) \\
\end{array}$ & $\begin{array}{l}56.539 * * * \\
(2.983) \\
\end{array}$ \\
\hline $\begin{array}{l}\text { Feeder Dummy } \\
\text { (FEEDERD) }\end{array}$ & $\begin{array}{l}-47.597 * * * \\
(-2.344) \\
\end{array}$ & $\begin{array}{l}0.863 \\
(0.014) \\
\end{array}$ & $\begin{array}{l}-21.035 \\
(-0.447) \\
\end{array}$ & $\begin{array}{l}5.061 \\
(0.356) \\
\end{array}$ & $\begin{array}{l}15.558 \\
(0.653) \\
\end{array}$ \\
\hline $\begin{array}{l}\text { Fareless Zone } \\
\text { Dummy (ZONE 0) }\end{array}$ & $\begin{array}{l}71.728 * * * \\
(4.172)\end{array}$ & & & & \\
\hline Constant & $\begin{array}{l}-78.534 * * * \\
(-6.422) \\
\end{array}$ & $\begin{array}{l}-339.16 * * * \\
(-9.025) \\
\end{array}$ & $\begin{array}{l}-174.8 * * * \\
(-6.375) \\
\end{array}$ & $\begin{array}{l}-72.37 * * * \\
(-8.653) \\
\end{array}$ & $\begin{array}{l}-94.02 * * * \\
(-7.358) \\
\end{array}$ \\
\hline $\mathrm{R}^{2}$ & 0.53 & 0.75 & 0.65 & 0.70 & 0.69 \\
\hline Mean of Dep. Var. & 61.55 & 237.67 & 139.08 & 45.598 & 66.389 \\
\hline $\mathrm{N}$ & 166 & 168 & 184 & 174 & 149 \\
\hline
\end{tabular}

Numbers in Parentheses are calculated t statistics;

*** Significant at the five percent level;

** Significant at the ten percent level. 
the afternoon peak, mid-day, and evening period, respectively, but only about 16 rides in the night and morning peak periods. This is generally what is expected. Outbound rides are concentrated in the afternoon peak period, and are small in the morning peak and night periods.

Places of employment are major sources of boarding riders in the outbound direction. Employment density is the most important factor that determines the transit ridership. It is the most highly significant variable in the outbound models. It generates the highest ridership in the afternoon peak period and the second highest in the mid-day period. It generates less ridership in the evening and night periods.

Population downstream is another major factor that determines boarding rides for outbound direction. Population downstream is the total population in downstream fare zones. For example, population downstream in the fare zone 0 is the total population in zones 0,1 , 2 and 3; while population downstream in the fare zone 2 is total population in zones 2 and 3. 1000 population downstream can generate 5 rides in the afternoon peak period, about 4 rides in the mid-day period, and 0.66 and 0.55 rides in the evening and night periods. This variable is highly significant in the afternoon peak, mid-day and evening periods, but not statistically significant in the night period.

Population rather than population downstream is used in the morning peak period, because most morning trips are home-to-work trips, it is the population rather than population downstream that determines the boarding rides in a fare zone. The total population is significant in explaining variations of boarding rides in the morning peak period.

Income factor is also significant in the mid-day, evening and night periods. The reason of including household with income less than $\$ 25,000$ in this three time periods is that not all outbound trips are work-to-home trips. There may be some other trips that made by rides from places of residence. Income factor is not significant in the morning peak period and not 
included in the afternoon peak model, this is because the peak transit commuters are mostly choice riders, and income is not an important determinant for choice riders' mode choice (TriMet, 1993).

The ridership on complementary and competing routes are more significant than that in inbound models. The reason of this difference is not clear. Coefficients of alighting from complementary routes are positive across all time periods and significant in the morning peak, mid-day and afternoon peak periods. The coefficients show that the average 19 percent of ridership transfer from complementary routes to the route of interest in the morning and afternoon peak period, and about 17 percent riders transferring in the mid-day periods. There are fewer transfers in the evening and night periods.

Ridership on the competing routes negatively contribute to the ridership on the route of interest. Coefficients of this variable have the expected sign in all time periods and highly significant in the mid-day, afternoon peak and evening time periods.

The fare zone dummy variable is only used in the morning peak period. It is positive and significant for the fareless zone. The significant fareless zone dummy indicates there are some transfers in the downtown area. This model did not use alightings from inbound routes as an input for the outbound ridership, because downtown is the destination of many inbound riders, including alighting in downtown from all inbound routes as an input to explain boarding rides on outbound routes will introduce noise. But there does exist some transfers in the downtown area for outbound routes, the fare zone dummy variable captures these transferring activities in the morning peak hours. But the fareless zone dummy is not used in other time periods. The high employment density in the downtown area would otherwise confound the fareless zone dummy variable.

The route typology dummy variables show there exists some ridership difference 
between different route types after controlling for other variables. In general, crosstown routes have significantly high ridership than the radial routes in the night period, and feeder routes have significant less ridership than the radial routes in the morning peak period, but they have no significant difference in other time periods. Caution is needed to interpret these results, because other variables are different, the coefficients of route dummy variables are the effects after controlling for other variables. Radial routes serve into downtown, the large employment density in downtown area can explain a large part of the variations of transit ridership on radial routes. Crosstown routes do not serve into downtown, the smaller employment density along their service area can explain less variations of their ridership, the remaining variations are captured in the crosstown dummy variable. Therefore, the coefficient for crosstown dummy variable is positive, even though the crosstown routes may have the similar ridership as radial routes. Similarly, the difference of employment density between radial routes and feeder routes also reduce the effects of feeder route dummy variable. Even though the difference between observed ridership on radial routes and feeder routes are large, after controlling for other variable, the route type effect becomes small.

The goodness of fit is similar to the demand equations for the inbound direction. The $R^{2} s$ are over 0.65 for the mid-day, afternoon peak, evening, and night, ranges from 0.65 for the afternoon peak model, to 0.75 for the mid-day model. The $\mathrm{R}^{2}$ is smaller for the morning peak period, it is only 0.53 .

\section{Supply Equations}

Service supply for outbound direction is mainly determined by the ridership in 1989, current ridership, population and route typology. The ridership in 1989 is the most significant variable across all time periods. The coefficients range from 0.365 in the mid-day period to 
0.709 in the evening period. Based on the ridership in 1989 alone, service quantity for the outbound direction is provided the most in the evening period, and the least in the mid-day period. One hundred rides in 1989 at a whole route are provided about 71,47 and 46 seats at each zone in the evening, morning peak and night periods (Table 6.5), and about 37 and 37 seats in the afternoon peak and mid-day periods.

TABLE 6.5 Supply Equations for Outbound Direction

\begin{tabular}{|c|c|c|c|c|c|}
\hline \multicolumn{6}{|c|}{ Dependent Variable $=$ Total Seats $\left(\operatorname{LOS}_{\mathrm{iz}}\right)$} \\
\hline Independent Variables & AM Peak & Mid-day & PM Peak & Evening & Night \\
\hline $\begin{array}{l}\text { Ridership at Current } \\
\text { Planning Period }\left(\mathrm{R}_{\mathrm{iz}}\right)\end{array}$ & $\begin{array}{l}0.528 * * * \\
(2.176)\end{array}$ & $\begin{array}{l}0.106 \\
(1.07)\end{array}$ & $\begin{array}{l}0.172 * * * \\
(5.139)\end{array}$ & $\begin{array}{l}-0.062 \\
(-0.456)\end{array}$ & $\begin{array}{l}0.231 \\
(0.821)\end{array}$ \\
\hline $\begin{array}{l}\text { Ridership in } 1989 \\
\left(\mathrm{R} 89_{\mathrm{i}}\right)\end{array}$ & $\begin{array}{l}0.464 * * * \\
(16.8)\end{array}$ & $\begin{array}{l}0.365 * * * \\
(16.89)\end{array}$ & $\begin{array}{l}0.376 * * * \\
(28.56)\end{array}$ & $\begin{array}{l}0.709 * * * \\
(19.09)\end{array}$ & $\begin{array}{l}0.474 * * * \\
(10.50)\end{array}$ \\
\hline Population ( $\mathrm{POP}_{\mathrm{iz}}$ ) & $\begin{array}{l}-0.0067 * * * \\
(-3.793)\end{array}$ & $\begin{array}{l}-0.0082^{* * *} \\
(-2.842)\end{array}$ & $\begin{array}{l}-0.0011 \\
(-1.504)\end{array}$ & $\begin{array}{l}0.00053 \\
(0.666)\end{array}$ & $\begin{array}{l}0.0033 \\
(1.397)\end{array}$ \\
\hline $\begin{array}{l}\text { Crosstown Route } \\
\text { Dummy } \\
\left(\text { CROSTWND }_{i}\right)\end{array}$ & & $\begin{array}{l}-52.099 \\
(-0.702)\end{array}$ & $\begin{array}{l}-91.39 * * * \\
(-3.715)\end{array}$ & $\begin{array}{l}-21.563 \\
(-1.331)\end{array}$ & $\begin{array}{l}-59.141 \\
(-0.977)\end{array}$ \\
\hline $\begin{array}{l}\text { Feeder Route Dummy } \\
(\text { FEEDERD })_{i}\end{array}$ & $\begin{array}{l}130.09 * * * \\
(3.826)\end{array}$ & $\begin{array}{l}43.286 \\
(0.619)\end{array}$ & $\begin{array}{l}9.932 \\
(0.455)\end{array}$ & $\begin{array}{l}22.044 \\
(1.082)\end{array}$ & $\begin{array}{l}26.274 \\
(0.414)\end{array}$ \\
\hline Constant & $\begin{array}{l}123.37 * * * \\
(6.56) \\
\end{array}$ & $\begin{array}{l}403.27 * * * \\
(10.57) \\
\end{array}$ & $\begin{array}{l}138.39 * * * \\
(12.27)\end{array}$ & $\begin{array}{l}116.3 * * * \\
(11.37) \\
\end{array}$ & $\begin{array}{l}120.3 * * * \\
(3.688) \\
\end{array}$ \\
\hline $\mathrm{R}^{2}$ & 0.81 & 0.80 & 0.90 & 0.84 & 0.63 \\
\hline $\begin{array}{l}\text { Mean of Dependent } \\
\text { Variable }\end{array}$ & 336.99 & 894.25 & 353.07 & 267.75 & 437.93 \\
\hline
\end{tabular}

* Numbers in Parentheses are calculated t statistics;

*** Significant at the five percent level;

** Significant at the ten percent level.

Current ridership at each fare zone is highly significant in explaining service supply in the morning peak and afternoon peak period. It is not significant in the mid- 
day, evening and night periods (Table 6.5). It indicates that service supply is more responsive to current demand in the peak hours, and less responsive to current demand in the off-peak period. It is consistent with the Tri-Met's service standard that during the peak hours, service is planned based on the demand, while service in the off-peak period is scheduled based on the policy headway (Tri-Met, 1989).

Like the inbound supply models, the coefficients for population are consistently negative in the morning peak, mid-day and afternoon peak periods and statistically significant in the morning peak, mid-day periods. They are not significant in the afternoon peak, evening and night periods. This may be explained by the same way as in the inbound models. That is, due to the service expansion to low-density areas, the population inside the service areas is small but the service is no less because of the policy to run all buses the entire length of a route. So the service supply is negatively correlated with population after controlling for ridership. Unlike the inbound model the employment density is not included in the outbound models because it is highly correlated with the current ridership.

The positive coefficients of the feeder route dummy variable indicate the feeder routes are generally over-supplied after controlling for the ridership. But the feeder route is only significant for the morning peak hours. The negative coefficients for the crosstown route dummy variable indicate the crosstown routes are under-supplied after controlling for ridership and other variables, especially in the afternoon peak hours.

The overall goodness of fit of supply equations is quite good given only so few variables. The $R^{2}$ s are $0.81,0.80,0.90$ and 0.84 for the morning, midday, afternoon 
and evening periods. Like the inbound supply equation the $\mathrm{R}^{2}$ is low for the night model, it is 0.63 .

\section{Equations for Competing Routes}

Four variables are included to explain the variations of the ridership on competing routes: transit frequency in all competing routes, level of service on the route of interest, the percentage of population in the overlap areas between the route of interest and its competing routes, and the fareless zone dummy variable. These variables have the expected sign (Table 6.6). More frequent service on the competing routes generates more ridership on those routes. But higher level of service on the subject routes will draw rides away from its competing routes and result in less ridership on its competing routes. Furthermore, the more population in the overlap area will increase the competing effects.

The fareless zone dummy variable is used as an independent variable in this equation because more than half of outbound riders board transit in the fareless zone (See Table 4.4 in Chapter 4), and most competing activities occur in this fareless zone. The large positive and significant coefficients of the fareless zone dummy variable reinforce this observation.

The $R^{2} s$ for the equations for competing routes are between 0.71 and 0.82 . They are better than the inbound models, because most competing activities occur in the fareless zone, adding a fareless zone dummy variable explains a large variance of the ridership for competing routes. 
TABLE 6.6 Equations for Competing Routes for Outbound Direction

\begin{tabular}{|c|c|c|c|c|c|}
\hline \multicolumn{6}{|c|}{ Dependent Variable $=$ Total Ridership on Competing Routes $\left(R_{j}\right)$} \\
\hline Independent Variables & AM Peak & Mid-day & PM Peak & Evening & Night \\
\hline $\begin{array}{l}\text { Frequency on } \\
\text { Competing Routes } \\
\left(\mathrm{FRQ}_{\mathrm{j} z}\right)\end{array}$ & $\begin{array}{l}17.674 * * * \\
(5.86)\end{array}$ & $\begin{array}{l}83.513^{* * *} \\
(16.21)\end{array}$ & \begin{tabular}{|l}
$27.658 * * *$ \\
$(9.102)$
\end{tabular} & $\begin{array}{l}16.247 * * * \\
(12.00)\end{array}$ & $\begin{array}{l}36.974 * * * \\
(14.22)\end{array}$ \\
\hline $\begin{array}{l}\text { Seats Supplied on the } \\
\text { Route of Interest } \\
\left(\operatorname{LOS}_{\mathrm{i}}\right)^{*} \text { OVPOPPC }_{\mathrm{ij} z}\end{array}$ & $\begin{array}{l}-0.102 \\
(-0.848)\end{array}$ & $\begin{array}{l}-0.030 \\
(-0.154)\end{array}$ & $\begin{array}{l}-0.396 \\
(-1.574)\end{array}$ & $\begin{array}{l}-0.0032 \\
(-0.021)\end{array}$ & $\begin{array}{l}-0.212 * * \\
(-1.862)\end{array}$ \\
\hline $\begin{array}{l}\text { Percentage of } \\
\text { Population in the } \\
\text { Overlap Arisa } \\
\left(\text { OVPOPPC }_{\mathrm{ij} 2}\right)\end{array}$ & $\begin{array}{l}-35.492 \\
(-0.656)\end{array}$ & $\begin{array}{l}-366.79 * * \\
(-1.665)\end{array}$ & $\begin{array}{l}-220.34 \\
(-1.508)\end{array}$ & $\begin{array}{l}-81.468 \\
(-1.632)\end{array}$ & $\begin{array}{l}-26.305 \\
(-0.407)\end{array}$ \\
\hline Fareless Zone Dummy & $\begin{array}{l}260.09 * * * \\
(8.62)\end{array}$ & $\begin{array}{l}1429.1 * * * \\
(12.98)\end{array}$ & $\begin{array}{l}1398.2 * * * \\
(15.64)\end{array}$ & $\begin{array}{l}334.54 * * * \\
(12.29)\end{array}$ & $\begin{array}{l}387.29 * * * \\
(9.451)\end{array}$ \\
\hline Constant & $\begin{array}{l}-51.15 * * * \\
(-2.7)\end{array}$ & $\begin{array}{l}-163.37 * * * \\
(-2.367)\end{array}$ & $\begin{array}{l}-72.213 \\
(-1.236)\end{array}$ & $\begin{array}{l}-47.58 * * * \\
(-2.673)\end{array}$ & $\begin{array}{l}-88.747 * * * \\
(-3.956)\end{array}$ \\
\hline$\overline{R^{2}}$ & 0.77 & 0.82 & 0.71 & 0.71 & 0.77 \\
\hline $\begin{array}{l}\text { Mean of Dependent } \\
\text { Variable }\end{array}$ & 223.17 & 891.15 & 539.74 & 166.11 & 2224.39 \\
\hline
\end{tabular}

Numbers in Parentheses are calculated $t$ statistics.

*** Significant at the five percent level;

** Significant at the ten percent level.

\section{THE COMPARISON BETWEEN A SINGLE-EQUATION MODEL AND A}

\section{SIMULTANEOUS-EQUATIONS MODEL}

The major difference between a single-equation and a simultaneous-equations model is that the single-equation model does not consider cross-equation interactions, there is only one-way relationship between dependent and independent variables and no feedback effects between them. While in a system of simultaneous equations, all the endogenous variables are determined simultaneously. A change in any endogenous 
variable will affect all other endogenous variables and itself. For example, considering a relationship between transit ridership and level of service, in a single-equation model, ridership is determined by the level of services. A change of level of service will cause changes on ridership, but the subsequent changes of ridership will have no further impact on the level of service. A simultaneous-equations model considers the transit ridership and the level of service simultaneously. A service change will affect ridership, the subsequent ridership changes will also affect service, the service change will further affect ridership, and so on. This iteration process is shown in Figure 6.1. The iteration process will not stop until it converges, i.e., until both endogenous variables reach an equilibrium point and there are no further changes in either ridership or service.

For example, assume there is one unit of level of service (one seat) increase on a route $\mathrm{i}$. This route has a competing route which are 100 percent overlaid with a competing route. Using the coefficients from the morning peak inbound model, the iteration process is shown in Table 6.7.

In the first iteration, a seat increase on the route $\mathrm{i}$ increase 0.289 rides on the route $\mathrm{i}$, but it also decrease 0.182 rides on the competing route $\mathrm{j}$. This ridership decrease on route $\mathrm{j}$ will increase $0.0359(=(-0.182) *(-0.197))$ rides on the route $\mathrm{i}$. So the ridership on the route $i$ is $0.3249(0.0359+0.289)$. The ridership increase on route i will increase service supply by 0.0526 seats, and the increased service supply will further increase ridership on the route $i$ and decrease ridership on route $j$, and so on. Table 6.7 shows that after five iterations, the simultaneous equations converge. So the final ridership impact of one unit of service increase on route $i$ will increase 0.3432 
rides on the route $i$ and decrease 0.1923 rides on the competing route $j$, and the net effect is 0.1509 rides.

TABLE 6.7 Iterative Process of Estimating Ridership Impacts of One Unit of Service Change

\begin{tabular}{||l|r|r|r||}
\hline Iterations & $\begin{array}{l}\text { Ridership Changes } \\
\text { on the Route of } \\
\text { Interest }\left(\mathrm{R}_{\mathrm{i}}\right)\end{array}$ & $\begin{array}{l}\text { Ridership Changes on } \\
\text { the Competing Routes } \\
\left(\mathrm{R}_{\mathrm{j}}\right)\end{array}$ & $\begin{array}{l}\text { Neat Ridership } \\
\text { Changes }\left(\mathrm{R}_{\mathbf{i}}+\mathrm{R}_{\mathrm{j}}\right)\end{array}$ \\
\hline 1 & 0.3249 & -0.1822 & 0.1429 \\
\hline 2 & 0.3421 & -0.1918 & 0.1504 \\
\hline 3 & 0.3431 & -0.1923 & 0.1508 \\
\hline 4 & 0.3432 & -0.1923 & 0.1509 \\
\hline 5 & 0.3432 & -0.1923 & 0.1509 \\
\hline
\end{tabular}

\section{This final}

ridership impact is the

total impact of service change, which is different from the initial impact (the coefficient in the equations). For the morning peak inbound model, the initial ridership impact of one

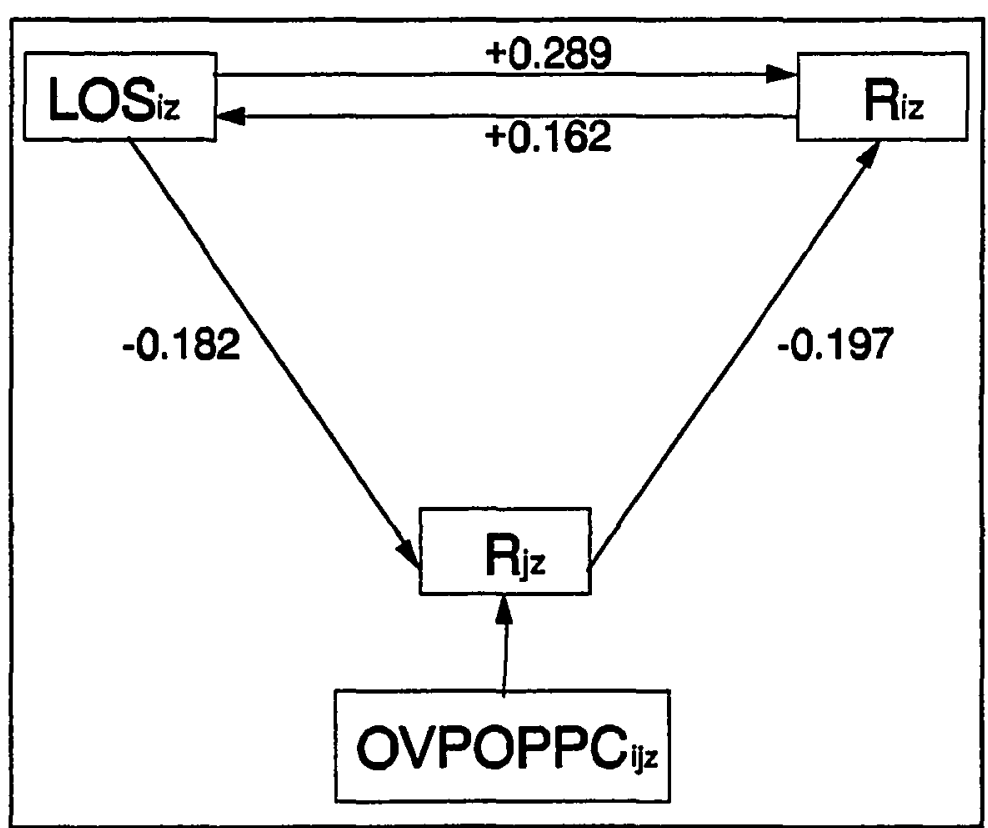

Figure 6.1 Estimated Simultaneous Effects of Endogenous Variables. 
unit service change is 0.289 , but the total impact is 0.3432 . This difference reflects the cross-equation interactions in the simultaneous equation model. This is one of the major differences between a single-equation and a simultaneous-equation model.

The second major difference between the single-equation and a simultaneousequation model is that in a single-equation model, the dependent variable is only determined by variables in that equation. But in a simultaneous-equations model, a change of exogenous variables of one equation will have impacts on the endogenous (dependent) variables in other equations too, even though this variable is not included in that equation. For example, the employment density is only included in the supply equation in the inbound models (Figure 6.2), so a change of employment density will first affect the service supply $\left(\operatorname{LOS}_{\mathrm{i} z}\right)$. The change of service supply will affect the ridership on the route of interest $\left(R_{i z}\right)$ in the demand equation, it will also affect ridership on the competing routes $\left(R_{\mathrm{j} z}\right)$ through the equation for competing routes. The ridership changes on competing routes will further affect ridership on the route of interest $\left(R_{i z}\right)$, and the ridership change on the route of interest will in turn affect the service in the supply equation. Therefore, the change of employment can affect all three endogenous variables: service supply, ridership on the route of interest and ridership on competing routes through cross-equation relationship, although the employment variable is only included in the supply equation.

This iterative process of endogenous variable changes across equations corresponding to an exogenous variable change can be illustrated by a concept of an impact multiplier (Greene, 1993). An impact multiplier is the effect of any exogenous 
variable changes upon all endogenous variables at the current time period. It shows how the initial changes in an exogenous variable impact all the endogenous variables in the whole system.

The third major difference between a single-equation and a simultaneousequation model is that the concept of the net effect of service changes. According to a single-equation model, a service improvement on a route will increase ridership on that route. These ridership increase is assumed as the net effect of that service change. Ridership on other routes are assumed as constant. While in a simultaneous-equation model, a service change on one route is assumed to have impacts on both the subject

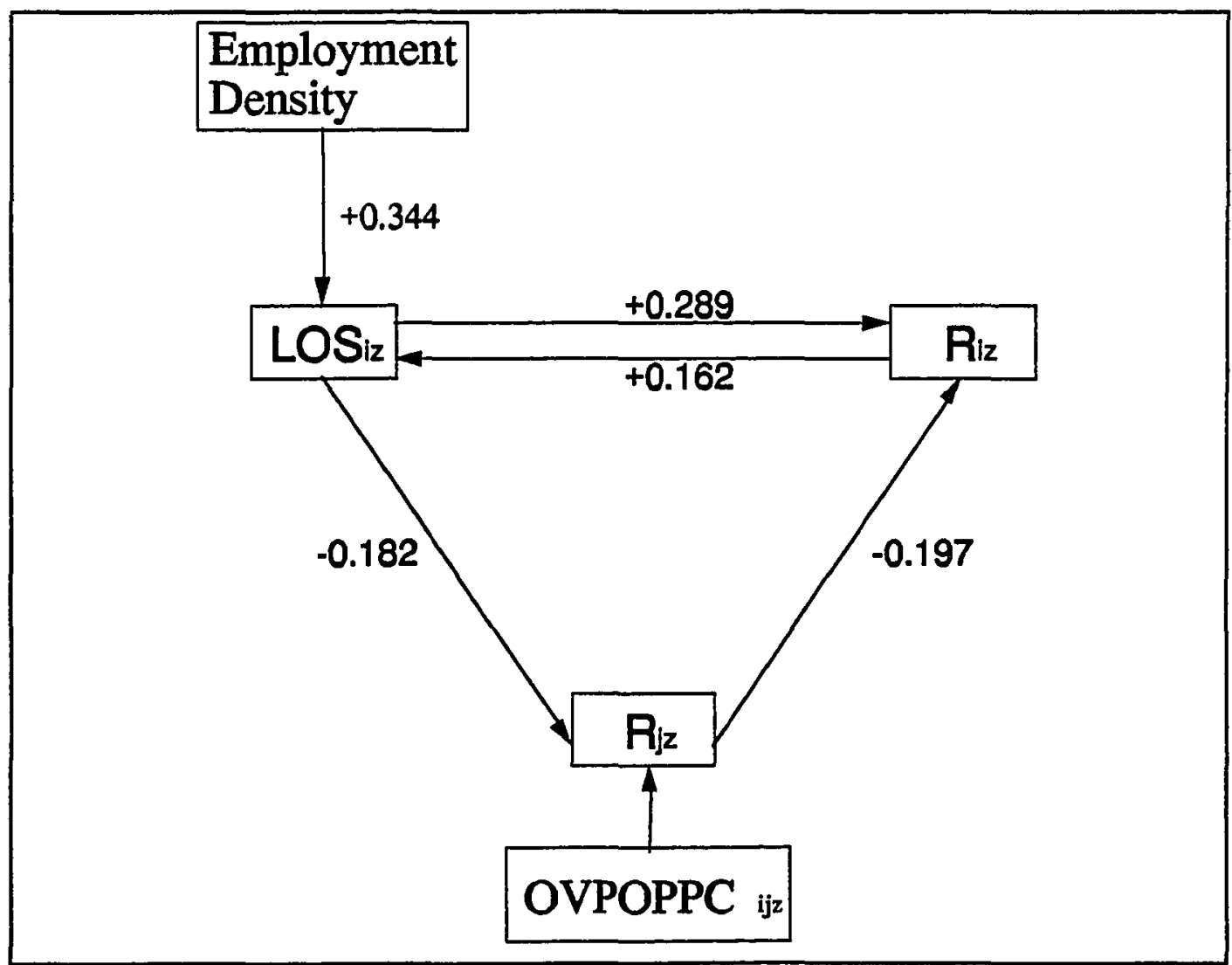

Figure 6.2 The Impacts of Employment changes upon Endogenous Variables 
route with service changes and its competing routes, and the net effect of the service changes is the sum of ridership changes on the subject route and its competing routes.

The net effect is also related with how strong the competing routes relate to the subject route. That is the net effect is related with the population percentage in the overlap area. The more overlap, the more competing effects and the less the net effects. This can be illustrated by an example.

An example using the results from the morning peak inbound model is shown in Table 6.8. It assumes that there is an additional 100 seats increase on a route $i$, the total ridership impact on the route $\mathrm{i}$ and its competing routes $\mathrm{j}$, and the net ridership impact are calculated in Table 6.8.

TABLE 6.8 Net Effects of Service Changes of Additional One Hundred Seats on an Inbound Route in the Morning Peak Period

\begin{tabular}{|r|r|l|r||}
\hline $\begin{array}{l}\text { Percentage of } \\
\text { Population in } \\
\text { Overlap Area (\%) }\end{array}$ & $\begin{array}{l}\text { Ridership Changes } \\
\text { on the Route of } \\
\text { Interest }\left(R_{\mathrm{iz}}\right)\end{array}$ & $\begin{array}{l}\text { Ridership Changes } \\
\text { on Competing } \\
\text { Routes }\left(\mathrm{R}_{\mathrm{j} z}\right)\end{array}$ & $\begin{array}{l}\text { Net Ridership } \\
\text { Changes } \\
\left(\mathrm{R}_{\mathrm{iz}}+\mathrm{R}_{\mathrm{j} \mathrm{z}}\right)\end{array}$ \\
\hline 100 & 34.32 & -19.23 & 15.09 \\
\hline 60 & 32.88 & -15.35 & 17.53 \\
\hline 50 & 31.77 & -11.49 & 20.28 \\
\hline 30 & 31.33 & -9.57 & 21.76 \\
\hline 10 & 30.70 & -5.74 & 24.96 \\
\hline 0 & 30.38 & -1.91 & 28.47 \\
\hline & 30.34 & 0.00 & 30.34 \\
\hline
\end{tabular}

The results from Table 6.8 shows that the stronger the relationship of two 
routes, the smaller the net ridership effect corresponding to a service change. As the percentage of population in the overlap area decrease, the ridership decrease on the competing routes diminishes, but the net effect increases. If the two routes totally overlap, an 100 seat increase on the route $\mathrm{i}$ will increase about 34 rides, but it will reduce about 19 rides, so the net effect is about 15 more rides. If the two routes 50 percent overlap, an 100 seat increase on the route $i$ will increase about 31 rides on that route, and it will also decrease about 10 rides on the competing routes, so the net effect is about 21 more rides.

In contrast, according to the results of a single-equation model, an 100 seat increase will generate about 26 more rides. This increased rides are assumed to be new rides and are net effects of the service changes, regardless of the relationship with other routes. Comparing the results of a single-equation and a simultaneous-equation model, the single-equation model under-estimate the ridership responses on the route with service changes and over-estimate the net effects, if the route has competing routes and the overlap population is over 20 percent.

From the analysis above, it is possible to differentiate between the synergistic effect and competing effect corresponding to service changes on one of the routes. The synergistic effect is represented by the net effects, while the competing effect is represented by the ridership reduction on the competing routes. Both competing and synergistic effects are related with the percentage of population in the overlap area. For the example shown, the synergistic effect of one hundred seats increase is 10 rides while the competing effect is 19 rides if two routes operate on the same road. The 
synergistic effect is smaller than the competing effect, indicating that the major ridership response to service changes is from current riders shifting among routes rather than new rides being generated. If two routes overlap 50 percent, the synergistic effect (19 rides) is larger than the competing effect (about 10 rides).

\section{SUMMARY}

Ten time-specific and direction-specific models has been developed in the morning peak, mid-day, afternoon peak, evening and night time period, and for inbound and outbound direction. The models show that the level of service provided significantly contributes to transit ridership, and this finding is consistently across all time-periods and both directions. In addition to the level of services, inbound demand is mostly determined by the number of persons by places of residence, while outbound demand is mostly determined by the employment density. Park-and-ride lots provided by TriMet are also highly significant to explain variations of transit ridership in the morning peak and mid-day time periods on inbound routes.

The model results indicate a significant spatial variation of transit ridership. For the inbound direction, route segments in the urban areas (fare zones 1 and 2) have larger boarding rides than in suburban areas (fare zone 3), after controlling for other variables. For the outbound direction, transit ridership is concentrated in downtown Portland area, and ridership in the fareless zone is significantly larger than any other fare zone.

Service supply is mainly determined by the ridership in the previous planning 
years and current ridership. It indicates that service supply is affected by the observed ridership at the time of planning. But the planners and schedulers are flexible of adjusting the service level according to ridership fluctuations. Because transit service needs to cover a broad area, service is extended to low density areas. Those low density areas have low ridership and low population coverage inside a quarter mile buffer area around a transit route, therefore, it has relatively higher service level on the per person and per ridership bases.

A simultaneous-equation model has three major advantages over a singleequation model. First of all, a simultaneous-equations model considers transit demand, supply and inter-route relationship simultaneously. An initial service change will affect ridership on the route with service changes and its competing routes, as well as the level of service itself through a cross-equation relationship. The total impact of service changes is not the same as the coefficients in the structural equations. While in a single-equation model, the ridership impact of a service change is determined by the coefficients in that equation. And the ridership changes have no further impact on service supply.

Next, in a simultaneous equation, a variable change in any equations will have impacts on other endogenous variables through an iterative cross-equations effect or an impact multiplier effect. While a variable change in a single-equation model can only affect its dependent variable, there is no cross-equation effects.

Finally, a simultaneous-equation model can estimate the net effects of a service change, while a single-equation model cannot. The model results show that the net 
effect of a service change is small if a route operate on the same road with other competing routes. Most of the ridership increase on the route with service changes are current rides shifting from other existing routes, the new rides generated by the service increase are small. 


\section{CHAPTER 7}

\section{APPLICATIONS OF THE MODELS: \\ SYSTEM LEVEL POLICIES AND ROUTE-LEVEL PLANNING}

The model results can be implemented in many ways. They can be implemented for analysis at the system level and simulation at the route and route segment level. At the system level, the model can be used to assess service planning and land use planning policies. The model can also be used for individual route analysis, such as proposed future transit-intensive corridor analysis, and new route analysis. The models are especially useful for route level "what-if" scenario analysis. This chapter will discuss these potential implementation of the models at both the system and the route level.

\section{SYSTEM LEVEL}

Although the models are developed for the route segment level, some of their results can be applied at the system level. Because the cross-section models were estimated on the average of all route segments, they can be applied as an average to all transit routes systemwide. The model results imply two major applications at the system level: transit service planning and land use planning. 


\section{A. Transit Service Planning}

The results from the route-segment models have important implications for system level service planning. The results reveal that there is a significant spatial and temporal differences of transit demand. These spatial and temporal variations of transit demand imply service supplies needs to be spatially and temporally differentiated.

Temporal implications of service planning. The coefficients of level of service in different time periods (Tables 6.1 and 6.4) shows that service supply in different time periods will result in different ridership. Service increases in the peak hours and mid-day period will result in more ridership than service increase in the evening and night periods. However, the transit users in the evening and night periods are more likely to be captive riders as indicated by the significant income variable in those time periods. Therefore, there is a trade-off between planning more transit service in the peak hours to increase service efficiency and planning more service in the evening and night periods to serve the disadvantaged.

Spatial implications of service planning. The significant fare zone dummy variables in the models indicate a strong spatial variation in transit demand. Urban areas (fare zones 1 and 2) have larger transit uses than suburban areas (fare zone 3 ) for the inbound direction (Tables 6.1 and 6.4). There are many reasons of these spatial differences, such as distance to downtown employment center, employment destinations and self-selection process as discussed in Chapter 6. An important implication of this results to service planning is that transit service increases in different areas may result in different ridership responses. 
To estimate a segment-specific coefficients of level of service, interaction variables of fare zone dummy with level of service can be substikuted for the zone dummy in the model. The model is then re-estimated. The estimation result for the morning peak inbound model is shown in Table 7.1. It indicates that the service supply in zone 2 has the largest ridership responses, followed by zone 3, while zone 0 and 1 have less responses. If transit service increases are used to increase coverage in fare zone 3 , the resulting ridership will be less than the same service increases in fare zone 2.

TABLE 7.1 Coefficients for Interaction Variables of Fare Zone Dummies with LOS $_{\mathrm{iz}}$ for Inbound Routes in the Morning Peak Period

\begin{tabular}{|l|l|l|l|l||}
\hline \hline Dependent Variable $=$ Boarding Rides $\left(\mathrm{R}_{\mathrm{iz}}\right)$ \\
\hline Interaction Variables & $\begin{array}{l}\text { LOS }_{\mathrm{iz}} * \\
\text { Zone 0 }\end{array}$ & $\begin{array}{l}\text { LOS }_{\mathrm{iz}} * \\
\text { Zone 1 }\end{array}$ & $\begin{array}{l}\text { LOS }_{\mathrm{iz}} * \\
\text { Zone 2 }\end{array}$ & $\begin{array}{l}\text { LOS }_{\mathrm{iz}} * \\
\text { Zone 3 }\end{array}$ \\
\hline Coefficients & 0.10119 & 0.28166 & 0.42598 & 0.3317 \\
\hline
\end{tabular}

Implications of competing effects. Another important implementation of the models for transit service planning at the system level is the competing effect. Increasing service at the system level cause the redistribution of existing riders among different transit routes, the net increase of transit ridership corresponding to service increases will be small. This implies that the increase of new express route service on the existing routes or adjacent to existing routes may cause shifting of riders from other routes, only a small part of the ridership are new riders. 


\section{B. Land Use Planning}

There is a strong effort to link land use planning and transportation planning in the Portland metropolitan area. The major objective is to constrain population growth inside the Urban Growth Boundary (UGB), and increase population density along major transit corridors. It is reasoned that the population density can support frequent transit service, and more frequent service can attract more people to use transit.

The spatial variations of transit ridership can be used to assess the effect of population growth. Population growth in the urban areas and suburban areas will have significantly different impacts on transit uses as illustrated by the significant fare zone dummy variables.

A more detailed model that interacts fare zone dummies with the population variable reveals the different coefficients of population in different fare zones (Table 7.2). The coefficient of population in fare zone 2 is the largest, and is the least in fare zone 3. For a same 1000 population increase, there will be a 16.5 ride increase in zone $1,18.7$ rides in zone 2 and only 5.8 rides in zone 3.

TABLE 7.2 Coefficients for Interaction Variable of Fare Zone Dummy with Population for Inbound Routes in the Morning Peak Period

\begin{tabular}{|l|l|l|l|}
\hline \hline Dependent Variable $=$ Boarding Rides $\left(\mathrm{R}_{\mathrm{i}}\right)$ \\
\hline Variables & $\begin{array}{l}\text { Population } * \\
\text { Zone 1 }\end{array}$ & $\begin{array}{l}\text { Population } * \\
\text { Zone 2 }\end{array}$ & $\begin{array}{l}\text { Population * } \\
\text { Zone 3 }\end{array}$ \\
\hline Coefficients & 0.0165 & 0.0187 & 0.0058 \\
\hline
\end{tabular}

If large population growth in the future occurs mainly in the suburban areas 
(fare zone 3), the growing population will not have the same impact on transit uses as in the urban areas. Therefore, the transit ridership will not be expected to increase as the same pace as population growth for the system as a whole.

Furthermore, if the future population growth is mainly in suburban areas, there may be a stronger political pressure of increasing transit services to serve suburban residents. These models offer an important tool for transit policy makers and service planners to analyze possible decision results, and to assist decision-making based on the trade-offs of providing more fixed services to broader areas at the cost of less efficiency of service, or to have more efficient transit service under stronger political pressure. The model results imply the need to search for other non-traditional transit services to serve suburban areas.

\section{ROUTE LEVEL}

The route level transit ridership estimation model is designed to serve as an analysis tool for individual transit routes and route segments. They are especially useful for "what-if" scenario analysis on existing routes and transit intensive corridors, and for new route analysis as well.

\section{A. Existing Route Analysis}

Transit planners are interested in estimating ridership responses to service changes, because service changes are the major area transit planners have some control. The service changes include changing service frequency, extending or reducing hours 
of service, expanding or shortening route length. These are some of the potential implementation fields at the route level.

Changes of service frequency will change the total level of service supply as represented by the total seats in the simultaneous-equation models. According to the models the change of seats in the demand equation will first affect the ridership on that route. At the same time, the seats change will also affect the ridership on the competing routes, the ridership changes on the route of interest and its competing routes will in turn affect the service supply. And further service changes will affect further ridership. This interactive process need to be iterated several times before the final results of ridership responses can be known. At the implementation stage of this study which will be conducted in the Summer of 1994, a program will be developed to implement this iterative process automatically.

For example, suppose the headway of one route changes from 20 minutes to 15 minutes in the morning peak periods, and assume the increased buses are standard buses and have 44 seats per bus. The total seat changes can be calculated in the following way:

$$
\begin{aligned}
{\Delta \text { LOS }_{i z}} & =\Delta \frac{\text { SERVICE TIME }_{\mathrm{iz}}}{\text { HEADWAY }_{\mathrm{iz}}} * \text { SEATS PER BUS } \\
& =\left(\frac{2 * 60}{15}-\frac{2 * 60}{20}\right) * 44 \\
& =(8-6) * 44 \\
& =88
\end{aligned}
$$

This service change will generate different ridership on that route and different net rides, depending on the relationship of this route with other competing routes. For 
example, if the route with service change overlap 50 percent with other routes, according to Table 6.8 , the increased 88 seats will increase about $28(0.3133 * 88)$ boarding rides on the subject route, they also decrease about $8(-0.0957 * 88)$ boarding rides on the competing routes. So the net effect of the headway changes from 20 minutes to 15 minutes is $20(28-8)$ more boarding rides in each fare zone.

Extending or reducing hours of service is the most likely option of service changes in the night period. Extending or reducing hours of service, like extending service from 9:00 pm to $10: 00 \mathrm{pm}$, or reducing service from 11:00 pm to 9:00 pm, and keeping the frequency unchanged, will affect the total seats supplied at the night period. The total seat changes can be calculated in the Equation (7.2). The calculated total seat changes will affect ridership through the iterative process discussed above.

$$
\Delta \text { LOS }_{\mathrm{iz}}=\frac{\Delta\left(\text { SERVICE TIME }_{\mathrm{iz}}\right)}{\text { HEADWAY }_{\mathrm{iz}}} * \text { SEATS PER BUS }_{\mathrm{iz}}
$$

For example, if a route extending service from 9:00 pm to $11: 00 \mathrm{pm}$, with the headway of 30 minutes, and the vehicle is a standard bus with 44 seats. The increased the level of service is calculated as follows:

$$
\begin{aligned}
\Delta \operatorname{LOS}_{i z} & =\frac{(2 * 60)}{30} * 44 \\
& =176 \text { (seats) }
\end{aligned}
$$

The increased service supply can be applied into the night model, and the ridership response can then be calculated.

Expanding or shortening route length will affect total population, income, or 
park-and-lot capacity, depending on the route configuration and the length of route expanded or shortened. A GIS technique needs to be used to digitize and buffer the expanded part of the route, and to allocate demographic data into the route buffer. The changes of all these variables on the expanded or shortened part will affect the ridership responses of the route, which can be calculated by applying the new values of those variables into the model.

\section{B. New Route Analysis}

To apply the models to new routes, the new route needs to be digitized first. It is then buffered by a quarter mile distance using GIS, and all socioeconomic and demographic data such as population, employment, income, high school students enrollment and park-and-ride lots are allocated into the buffered areas. GIS is also needed to identify and analyze the relationship of this new route with other routes, and to calculate the percentage of population in the overlap areas. The generated data will then be applied to the model for estimation.

There is no data for ridership in the previous planning year for the new route in the supply equation. Based on the planner's practice, the expected ridership of new routes is based on a similar route, the previous year's ridership can be drawn from a similar route or the average of similar routes.

Another way to overcome this data shortage is to ignore the supply equation and to estimate the demand equation and the equation for competing routes only, assuming the service will not change in the first experiment year. This assumption is not invalid 
according to the observation in Tri-Met service areas, where many new routes take an average of about a year to build its stable passenger basis and service planning is not based on the observed ridership at the first year.

However, caution is needed to apply the models to new transit routes. First of all, it takes time for a new route to stabilize its ridership. It will over-predict the ridership of a new route at the early stage of the route operation when the ridership is not stabilized. The model results are applicable only when the ridership is stabilized.

Secondly, the models are calibrated based on the existing routes, where there may be a self-selection process, i.e., people who currently use transit because there is an existing transit service so they choose to live there. For a new route area, the selfselection process may be the opposite, people choose to live in an area without transit service because they do not care about using transit. Therefore, even these two areas may have similar population, income and other demographic variables, these two groups of population may be different in the attitude and real behavior toward transit uses. Using the models calibrated on the existing routes to predict ridership on the new route may result in over-estimation.

\section{Transit-Intensive Corridor Analysis}

There is planning in the Portland metropolitan area for transit intensive corridors. These proposed corridors will be provided frequent service (about ten minutes a bus in the peak hours) and filled with high density land uses. By increasing level of service and land use density, the agency expects a high transit uses on these 
transit intensive corridors. The models can be used to estimate the ridership responses on these proposed corridors by considering the service increase and population increase simultaneously.

Several scenarios can be developed for these transit intensive corridors. Ridership can be estimated assuming service changes only, land use density changes only, or the combination of the two. For example, assuming headway is changed to 15 minutes, 10 minutes or five minutes, and the land use density does not change, what is the ridership response? What if only the population density changes? And what if both the level of service and residential density changes at different level?

Because the models are time and direction specific, to estimate the total daily ridership, all ten models have to be estimated and aggregated into one day ridership.

For example, assume there is an 1000 person increase in each fare zone except in zone 0 along the route 56 , and the service is planned to increase by reducing headway from 24 minutes of headway to 17 minutes. The current population density and the percentage of population in the overlap area with other competing routes in each fare zone are shown in Table 7.3. Transit planners are interested in the ridership responses of these population and service changes.

First, assume only service changes and other variables are constant, the ridership responses in each fare zone can be estimated using coefficients in Table 7.1 and taking into account of the population percentage in the overlap areas (OVPOPPC), the ridership increase on route $56\left(\Delta R_{i z}\right)$ and the net effects ( $\Delta$ Net $R_{i z}$ ) for the inbound direction in the morning peak period are calculated in Table 7.3. The ridership increase 
on route 56 is the largest in zone 2 , but the net ridership increase is the largest in zone 3 , because there is essentially no competing effect in zone 3 .

TABLE 7.3 Ridership Impacts of Headway Change From 24 min. to $17 \mathrm{~min}$.

\begin{tabular}{|r|r|r|r|r|r||}
\hline Zone & POP. Density & OVPOPPC (\%) & $\Delta \mathrm{LOS}_{\mathrm{iz}}$ & \multicolumn{1}{|l|}{$\Delta \mathrm{R}_{\mathrm{iz}}$} & $\Delta \mathrm{Net}_{\mathrm{iz}}$ \\
\hline 0 & 11.43 & 1.00 & 88 & 8.80 & 0.00 \\
\hline 1 & 4.99 & 0.99 & 88 & 25.88 & 10.73 \\
\hline 2 & 5.81 & 0.78 & 88 & 40.79 & 28.48 \\
\hline 3 & 3.04 & 0.02 & 88 & 31.04 & 30.80 \\
\hline line & & & & 106.51 & 70.01 \\
\hline
\end{tabular}

Next, assume only land use density changes, and for convenience and comparison, and assume population increase in zones 1,2 and 3 is the same, 1000 more people, and no population change in zone 0 . All other variables are constant. How many ridership will this population increase generate? To estimate ridership changes, Table 7.2 is used to estimate the initial impact on ridership, but the total ridership impact has to consider cross-equation effects. After several iterations the total impact of 1000 population increase is shown in Table 7.4. A same number of population increase can generate more than double the ridership in zones 1 and 2 than in zone 3.

Finally, assume both the population and service increase at the same time, what is the ridership responses? To estimate the total impact of both population changes and service changes, simply sum up the ridership changes responding to respective population changes and service changes. It is shown in Table 7.5. 
TABLE 7.4 Ridership Impacts of 1000 Person Increase on Line 56

\begin{tabular}{|c|c|c|c|c|c|}
\hline Fare Zone & $\Delta \mathrm{POP}_{\mathrm{iz}}$ & $\begin{array}{l}\text { Current POP. } \\
\text { Density }\end{array}$ & $\begin{array}{l}\text { New POP. } \\
\text { Density }\end{array}$ & $\Delta \mathrm{R}_{\mathrm{iz}}$ & $\Delta$ Net $R_{i z}$ \\
\hline 0 & 0 & 11.43 & 11.43 & 0 & 0 \\
\hline 1 & 1000 & 4.99 & 7.62 & 17.30 & 16.83 \\
\hline 2 & 1000 & 5.81 & 6.36 & 20.14 & 19.70 \\
\hline 3 & 1000 & 3.04 & 4.31 & 6.14 & 6.14 \\
\hline line & $3,000.00$ & & & 43.58 & 42.67 \\
\hline
\end{tabular}

TABLE 7.5 Ridership Impacts of Headway Change And Population Changes

\begin{tabular}{|c|c|c|c|c|c|}
\hline Zone & $\triangle \mathrm{POP}_{\mathrm{iz}}$ & $\begin{array}{l}\text { New Population } \\
\text { Density }\end{array}$ & $\begin{array}{l}\text { New } \\
\text { Headway }\end{array}$ & $\Delta \mathrm{R}_{\mathrm{iz}}$ & $\Delta$ Net $R_{i z}$ \\
\hline 0 & 0 & 11.43 & $17 \mathrm{~min}$ & 8.80 & 0.00 \\
\hline 1 & 1000 & 7.62 & $17 \mathrm{~min}$ & 43.18 & 27.56 \\
\hline 2 & 1000 & 6.36 & $17 \mathrm{~min}$ & 60.93 & 48.18 \\
\hline 3 & 1000 & 4.31 & $17 \mathrm{~min}$ & 37.18 & 36.94 \\
\hline line & 3000 & & $17 \mathrm{~min}$ & 150.09 & 112.68 \\
\hline
\end{tabular}

\section{Application Process of Route-Level Patronage Estimate}

The models can be used for route-level patronage estimate whenever any or all of the variables is altered. There are five general steps required for the application of the models in route-level patronage estimate.

Step 1. define the route and its service area;

Step 2. allocate socioeconomic and demographic data to the route's service area, and calculate the value of each variable in each fare zone;

Step 3. define the level of service to be provided on the route for each fare zone; 
Step 4. identify complementary and competing routes, and estimate the percentage of population in the overlap area with competing routes;

Step 5. estimate the patronage at the fare zone level and aggregate to the route level.

\section{A. Define the Route and Route Service Area}

The first step in applying the models is to digitize the route configuration in a machine-readable format map, define its service area, and segment the route with fare zones. The route's service area is defined as a quarter mile around the route, it is a half-mile-wide band.

GIS is a most efficient tool in this process. The TIGER line file or the Portland Regional Land Information Systems (RLIS, designed by METRO) can be used as the base map, the route configuration can be digitized based on the base map. The route service area is then defined using the buffer function in Arc/Info. The route buffer is segmented by overlaying it with the fare zone coverage.

\section{B. Spatial Data Allocation}

The second step is to allocate demographic and land use data to the route's service area. The allocation method is discussed in Chapter 3. The census block is recommended for population allocation if the block-level data are available. If the block-level data are not available as in most years, the block group or census tract data can be used. The allocation method based on land use types is a preferred choice, 
because the RLIS database is updated yearly. The land use categories can be derived from RLIS database. The population and employment data are then allocated to route's service area based on the proportion of residential and non-residential land areas inside the route buffer.

Income data are allocated to the route service area from the census data at the block group level, as discussed in Chapter 3. Some assumptions have to be made to estimate income in years that no income data is available at the block group level, like $1991,1992,1994$, etc. The first assumption could be that income does not change in short time periods (within five years), the income data in 1990 census can also be applied to later years from 1991 to 1995 . The second assumption could be that the income changes proportionally over the years. This means the percentage of households with less than median income is constant. Under this two assumptions the income data from 1990 need not to be adjusted. It should be noted, however, these two assumptions simplified the income data but may not be valid in the fast growing area, where household income has to be estimated using other methods.

Other data like park-and-ride lot capacity or usage, and high school student enrollment, can be updated yearly, and can be easily allocated to the route's service area, as discussed in Chapter 3.

\section{Define the Level of Service}

The level of service is defined as a combination of service time, headway and number of seats per bus. Service time is the number of minutes in service in a time 
period, like morning peak, mid-day, or afternoon peak. Headway is the number of minutes between two buses, and number of seats per bus is the total seat capacity in a bus vehicle. Once these three variables are given, the total level of service can be calculated using the formula shown in Equation 5.7.

\section{Inter-Route Analysis}

This step is to analyze the relationship of the route of interest with other routes, both complementary routes and competing routes. The strength of the competing routes is represented by the average percentage of population in the overlap area. The alighting on the complementary routes are aggregated in a fare zone, and the boarding rides on the competing routes are also aggregated in fare zones.

\section{E. Ridership Estimation}

The final step is to apply the generated data to the models in different time periods and directions. Because the models are simultaneous models, the ridership estimation is an iterative process. Several iterations is needed until the system is converged, i.e., until the ridership, level of service and ridership on competing routes are in equilibrium. Ridership on a route is the summation of ridership on the fare zones.

\section{SUMMARY}

The models developed in this study can be implemented both at the system level 
and at the route or route segment level. Transit service planning and land use planning policies can be analyzed at the system level. There are two important policy implications. The first one is that the different spatial distributions of transit service and population growth will have different impacts on transit uses. Service increase and population growth in urban areas (fare zone 1 and 2) will have higher impact on transit uses than in suburban areas. The second implication is that the transit service increase will cause ridership redistribution among routes. The new ridership (or the net ridership changes) will be small corresponding to transit service increases, if most of the route overlap with other competing routes.

The models are especially useful for route-level what-if scenario analysis. They are suitable for estimating ridership responses to service changes in different forms, such as frequency changes, changes of hours of service, changes of route configurations. They can be also used for new route analysis with some cautions. The models are not only suitable for single variable changes but also appropriate for multiple variable changes. They can be used to analyze proposed transit intensive corridors, and estimate possible ridership responses corresponding to changes in the level of service and land use density. 


\section{CHAPTER 8 \\ CONCLUSIONS AND \\ IMPLICATIONS FOR FUTURE RESEARCH}

Transit managers are under increasing pressure to provide efficient and effective transit services (Nickerson et al, 1983). Therefore, it is vital for transit agencies to have appropriate analytical tools to perform service-planning activities. Many quantitative models have been developed in recent years, including the large Urban Transportation Planning System models, cross-sectional, time-series regression models and the combination of cross-sectional and time-series models. Nevertheless, few transit agencies rely solely on the mathematical models and more on subjective judgement (Stopher and Mulhall, 1992). Slow adoption of these mathematical models may be due to the complexity of the mathematical models, or that the models have not reached the level of reliability and accuracy sufficient for the needs of transit planners.

This study has identified three major problems in the route-level transit patronage estimate modeling: lack of data consistency, ignoring of the simultaneous effects of transit demand and supply, and not taking account of interrelationships among transit lines. These three problems have been the major causes of inaccuracy in routelevel demand models.

The major focus of this dissertation has been to address these three problems 
in developing a route-level transit patronage model. The data consistency issue has been dealt with by utilizing GIS to allocate socioeconomic and demographic data to individual route service areas -- a quarter mile distance around a transit line. The results of data allocation show that various allocation methods would result in different allocation accuracy. But even a simple allocation based solely on the area percentage coverage would be an improvement of no allocation at all. An appropriate data allocation could significantly reduce measurement errors, and increase the validity, accuracy and consistency of spatial and attribute data in route-level demand modeling.

The empirical evidence indicates that simultaneity exists between transit demand and supply, and there is a strong interrelationship among related routes in a transit network. Transit demand is affected by the level of service supplied, while the service supply is influenced by the past ridership and current demand changes. A service change on a subject route not only affect the ridership on that route, it also affects the ridership on its competing routes that share the same road or on closely parallel roads.

An important finding of the simultaneous-equations models is that a service improvement will increase boarding rides on the subject route, but it may cause boarding ride decrease on its competing routes, so the net effects of that service increase is smaller than the boarding ride increase on the subject route. The magnitude of the net effects depends on the strength of the relationship with competing routes. The more the two routes overlap, the more competing effects and the less of the net effects of service changes. This is an important contribution of this dissertation.

These empirical results show that a simultaneous-equations model has its 
advantages over a single-equation model. It considers the cross-equation effects or feedback effects among endogenous variables. A change of one variable will affect all endogenous variables in the whole system through cross-equation relationships. A service change will affect ridership on the subject route and its related route, the change of ridership will in turn influence service supply. While in a single-equation model, the relationship between ridership and level of service is one-way, i.e., ridership is determined by the level of service. If services are increased on a route, the ridership is increased accordingly. Furthermore, all the ridership increase on that route is assumed to be new riders, and ridership on other routes are assumed unchanged. The empirical work in this study reveals that this is not the case. Failing to consider the cross-route effects would result in biased estimation both at the route level and at the system level. An OLS estimation of the demand equation has shown that a singleequation model over-estimates the net effects of a service increase at the system level, and under-estimates the ridership on the route with service changes.

The time- and direction-specific models developed in this study have revealed that there is a different demand patterns for different time periods and different directions. In other words, demand for transit service has a spatial and temporal variation. Inbound demand is largely determined by the number of residents and their characteristics at places of residence, while outbound demand is largely determined by employment density at places of employment. A large portion of demand comes from the urban areas that are closer to downtown Portland, while ridership in suburban areas is much less than the urban areas. This implies that extending and/or increasing 
services to suburban areas would be less efficient and less cost-effective. This spatial variations of transit demand also implies that influence factors have different impacts on transit demand. For example, population density in urban areas have more important impacts on transit uses than population density in suburbs. Therefore, increasing population density in suburban areas may not have the same effects of increasing population density in urban areas.

The temporal variations of transit demand indicate that transit services in offpeak periods are in general over-supplied controlling for ridership and compared with services in peak periods. It implies that increasing service in off-peak periods will be less efficient. However, the off-peak riders are more likely to be captive riders while peak riders are more likely to be choice commuters. This confirms the trade-off in transit planning policy between increasing service efficiency and increasing accessibility of disadvantaged.

This research represents an important extension of previous work in the area. It has made an important contribution in incorporating GIS technology in route-level transit demand modeling. GIS has been found to be a powerful and efficient tool in spatial data integration and inter-route relationship analysis. This research has made a major effort to address the service and ridership impacts on parallel and intersecting routes and to incorporate it into a simultaneous-equations model with transit demand and supply. This study is the first research to discuss the net effects of a service increase at the route level. 
A simultaneous-equation model has been recognized to have an advantage of estimating transit demand, supply and cross-route effects simultaneously in this study. However, it should also be recognized that a simultaneous-equations system model is very sensitive to specification errors, especially for a three-stage-least-squares and other full-information estimation methods. A specification error in one equation will impact other equations.

This research restricts the model function form as being linear. The linear form of the regression model assumes the linear relationship between transit ridership and its determinant variables. This assumption has rarely been challenged and tested empirically. It may be a valid assumption for demographic variables such as number of population, household and high school student enrollment, with transit patronage changes proportional to the changes of these variables. However, this restriction may be questionable when applied to transit service. At a very low level of service, increasing transit service will be more likely to attract transit riders, because choice riders are more influenced by transit service. However, if the existing level of service is high, increasing service may not generate much more transit patronage. In other words, the parameter of transit service may not be a constant, it may vary depending on the existing level of service. The relationship between transit ridership and transit service may not be linear. But a strong theory is needed to justify a specific non-linear function form.

Like other cross-sectional model, this study has assumed that all observation units are homogeneous. In other words, it assumes that the coefficients of variables are 
the same across all observations on each segment and on every routes. The significant dummy variables indicate that this may not be the case. It implies that for the same variable there may exist different coefficients for different zones at different route or route types. Although the zone dummy and route type dummy variables are used to capture the spatial differences, it should be noted, however, the effect of dummy variables only affects the intercept term, it cannot explain the between-unit variance (Sayrs, 1989). One conventional way to capture the various coefficients across observation units is to use the interaction term of the dummy variable and other variables, such as zone dummy interacts with population, or zone dummy with the level of service as illustrated in Chapter 7. The problem of this approach is that there are many variables, an assumption is needed to determine which variable(s) should be interacted with the dummy variables. If all variables are to be interacted with dummy variables, there will be too many variables in the model. In addition, there is a potentially strong correlations among interaction variables, because they are interacted with the same dummy variables.

Future research needs to consider model functional forms and about the homogeneity of observation unit. A non-parametric analysis is a good alternative in this regard. A non-parametric analysis differs from the traditional parametric model in that the parametric model has to specify a function form like a linear regression model, while the non-parametric analysis does not need to make any assumption about the functional form. The function form in a non-parametric analysis is unknown (Ullah, 1988; and Stock, 1989). The unknown function can be estimated using a non- 
parametric technique such as the kernel estimation. The response or regression coefficients vary from observation to observation in the non-parametric analysis. In the case of route-level demand modeling, if the basic observation is the route segment, the non-parametric estimation can estimate individual coefficients for different variables at different observations. For example, there would be different coefficients for population and the level of service in zones 1,2 , and 3 of route $A$, as well as on route $B, C$, and so on. Every observation has its own coefficients, and the function is not necessarily the same for each observation, neither a linear function nor a fixed non-linear form is assumed. It is truly flexible and depends on individual observations. It would be valuable to estimate a non-parametric model and compare the results with the linear simultaneous model discussed in this study.

Another potential improvement is to estimate the model at the transit stop level if reliable stop level data are available. Stop level estimation can reduce some aggregation errors in some variables like on time performance, and increase the accuracy of the measurement of variables. But the allocation of demographic variables like population and income to individual stop may cause some difficulties and errors, especially when the data are not available at the block level.

Finally, this study has only estimated cross-sectional models. These models can not capture the temporal variation of transit demand and supply over longer period of time. They are applicable to a short time period and in the relatively stable environment. they cannot answer questions like what if gas price rises dramatically, and what if there is a transit worker strike. Future research needs to take the temporal 
variation of transit demand and supf'y over time into account. A transfer function is more appropriate in this regard.

In spite of limitations of the linear model, this research has advanced substantially the state-of-the-art of transit route-level modeling. It is ready for implementation, and can be used in several ways. The model results can be implemented as transit service planning policy and land use policy at the system level. They can also be used as individual route analysis, such as transit-intensive corridor analysis and new route analysis. The model is especially useful for route-level "what-if" scenario analysis. 


\section{REFERENCES}

Agrawal, D.C. 1978, "The Factors Affecting Mass Transit Ridership: An Analysis," Transit Journal, pp. 55-66

Alperovich, G., M. A. Kemp and K. M. Goodman, 1977, "An Econometric Model of Bus Transit Demand and Supply," The Urban Institute Working Paper No. 5032-1-4, Washing, D.C.

American Public Transit Association, 1991, "Effects of Fare Changes on Bus Ridership," Washington, D.C.

Blakemore, M. J., 1984, "Generalization and Error in Spatial Data Bases," Cartographica 21, pp. 131-39

Cherwony, W. and L. Polin, 1977, "Forecasting Patronage on New Transit Routes," Traffic Quarterly, pp. 287-195

Curtin, John. F., 1968, "Effects of Fares on Transit Riding," Highway Research Record 213

Dial, R. B., G. S. Rutherford, and L. Quillian, 1979, Transit Network Analysis: INET, Urban Mass Transportation Administration, Report No. UMTA-UPM-20-79-3, U.S. Department of Transportation, Washington, D.C.

Ecosometrics, Inc., 1976, Methods of Predicting Rural Transit Demand, Prepared for Pennsylvania Department of Transportation

Dueker, Kenneth J. and Ric Vrana, 1992, "Dynamic Segmentation Revisited: A Milepoint Linear Data Model," Journal of the Urban and Regional Information Systems Association, 4(2):94-105

Dueker, Kenneth J. and Ric Vrana, 1991, "GIS Application in Urban Public Transportation: A Case Study of Tri-Met, Portland, Oregon," Proceedings of the 1991 Geographic Information Systems for Transportation Symposium, March 5-8, 1991, Orlando, Florida

Ferguson, Erik, 1991, "Temporal Effects of Incidents on Transit Ridership in Orange 
County, California," Transportation Research Record 1297

Ferreri, M. G. 1979, "Transit Price Elasticities Revisited," Transit Journal, pp. 65-71

Flowerdew, R., 1991, "Spatial Data Integration," in: Mahuire D J, M F Goodchild, D W Rhind (eds.) Geographic Information Systems: Principles and Application, Vol 1. Longman, London, pp. 375-387

Foerster, J. F. and N. Imlay, 1989, "Using Early Performance to Project Transit Route Ridership: Comparison of Methods," Transportation Research Record 1209

Gaudry M. 1975, "An Aggregate Time-Series Analysis of Urban Transit Demand: the Montreal Case," Transportation. Research. 9, 249-258.

Harmatuck D. 1975, "The Effects of A Service Interruption on Bus Ridership Levels in a Middle-Sized Community," Transportation Research 9, 43-54.

Horowitz, Alan J. 1984, "Simplifications for Single-Route Transit Ridership Forecasting Models," Transportation, 12, PP. 261-275

Horowitz, Alan J. and D. N. Metzger, 1985, "Implementation of Service Area Concepts in Single-Route Ridership Forecasting," Transportation Research Record 1037.

Horowitz, Alan J. 1987, "Extension of Stochastic Multipath Trip Assignment to Transit Networks," Transportation Research Record 1108

Hunt, David T., Stephen E. Still, J. Douglas Carroll, and Alan O. Kruse, 1986, "A geodemographic model for bus service planning and marketing," Transportation Research Record 1051

Kyte, Michael, G. J. Stoner, and J. Cryer, 1988, "A time-series analysis of public transit ridership in Portland, Oregon, 1971-1982," Transportation Research-A, Vol. 22A, N0. 5, pp. $345-59$

Lago, Armando, 1991, "Forecasting incremental ridership impacts form bus route service changes," Final Report, Project 40-2A, Washington, D.C., National Research Council, Transportation Research Board, National Cooperative Transit Research and Development Program

Lam, William and John Morrall, 1982, "Bus passenger walking: distances and waiting times: A Summer-winter comparison," Transportation Quarterly, Vol. 36, No. 3, pp. 407-421 
Lindquist, Peter S. 1990, "Zone modification method for systemwide mass transit ridership forecasting, " Transportation Research Record 1285

Lycan, Richard, 1993, "Income Estimates for Census blocks for Oregon and Proximity to EPA TRI Sites," Center for Population Research and Census and Department of Geography, Portland State University, Oregon, unpublished

Maddala, G.S. 1989, Introduction to Econometrics, New York: Macmillan Publication Company

Mayworm, Patrick, Armado M. Lago, J. Matthew McEnroe, 1980, "Patronage Impacts of Changes in Transit Fares and Services," Ecosometrics, Inc.

McLeod, Malcolm S. Jr., Kevin J. Flannelly, Laura Flannelly, and Robert W. Behnke, 1991, "Multivariate time-series model of transit ridership based on Honolulu," Transportation Research Record 1297

Multisystems, Inc. 1982, Route-Level Demand Models: A Review, Urban Mass Transportation Administration, U.S. Department of Transportation, DOT-1-82-6

Naylor, T. H., T. G. Seaks and D. W. Wichevn, 1972, "Box-Jenkins methods: an alternative to economic forecasting," International Statistical Review 40(2):123-137

Nelson, Charles R. 1973, Applied Time Series Analysis: For Managerial Forecasting, San Francisco: Holden Day

Nickerson, A. H., A. H. Meyburg, and M.A. Turnquist, 1983, "Ridership Estimation for Short-Term Transit Planning," Transit Research, Vol. 17B, No. 3, pp. 233-244

Nihan N. L. and Holmesland K. O. 1980, "Use of Box and Jenkins time-series techniques in traffic forecasting," Transportation 9, 125-143.

Okunieff, Paula and APTS Map and Spatial Database Working Group, 1994, "An Overview of the Map and Spatial Database User Requirements Document for Advanced Public Transportation systems (APTS)," Presented at the 1994 Geographic Information Systems for Transportation Symposium, April 11-13, 1994, Norfolk, Virginia, unpublished

Papacostas, C. S. 1987, Fundamentals of Transportation Engineering, Englewood Cliffs, New Jersey: Prentice-Hall, Inc.

Peng, Zhongren and Kenneth J. Dueker, 1993, "Error and Accuracy in Spatial Data Allocations," GIS/LIS '93 Proceedings, Minneapolis 
Prashker, Joseph, 1988, "Multipath capacity limited transit assignment using UTPS package," Institute of Transportation Studies, University of California, Irvine, UCI-ITS-WP-88-13

Pindyck, Robert S. and Daniel L. Rubinfeld, 1991, Econometric Models \& Economic Forecasts, New York: McGraw-Hill, Inc

Puller, David \& Kate Beard, 1990, "Specifying and tracking errors from map overlay," in GIS/LIS '90 Proceedings, Anaheim, California, Vol. 1, pp. 79-87

Sayrs, Lois W. 1989, Pooled Time Series Analysis, Newbury Park, CA: SAGE publications

Stock, James H., 1989, "Nonparametric policy analysis," Journal of the American Statistical Association, Vol. 84, No. 406, pp. 567-575

Stopher, Peter and Shawna Mulhall, 1992, "Route level patronage forecasting methods: a survey of transit operators," Presented at the 71st Annual Meeting, transportation Research Board, Washington, D.C.

Tri-Met, 1993, "Market Segmentation Study," prepared by Gilmore Research Group

Tri-Met, 1989, "Tri-Met Service Standards," Portland, Oregon

Tri-County Metropolitan Transit District, 1983, Bus Route Demand Models: Portland Prototype Study, Urban Mass Transportation Administration, U.S. Department of Transportation, DOT-1-83-37

Ullah, Aman, 1988, "Non-parametric estimation of econometric functionals, " Canadian Journal of Economics, Vol. XXI, No. 3, pp.625-658

Wang, G. H., 1981, "An intervention analysis of interrupted urban transit time-series data: Two case studies," 1981 Proceedings of the Business and Economic Statistics Section, 424-429. American Statistical association, Chicago, Illinois.

Wang, G., Ma Ling W. and Skinner D., 1982, "Modeling monthly transit ridership: Empirical evidence from seven U.S. transit authorities," U. S. Department of Transportation, Transportation Systems Center, Cambridge, MA.

Yuratovac, D. G., 1981, "Bus Route-Level Demand Modeling," Transportation Research Record No. 994, pp. 8-12, Washington, D.C. 
APPENDIX A Sample of Route-Segment Level Data Base*

171

\begin{tabular}{|c|c|c|c|c|c|c|c|c|c|c|}
\hline A & $\bar{A}$ & B & C & $\bar{D}$ & $E$ & $\mathbf{F}$ & $\mathbf{G}$ & $\mathrm{H}$ & 1 & $\mathbf{J}$ \\
\hline 1 & \multirow[b]{2}{*}{ Line } & \multirow[b]{2}{*}{ Dir } & \multirow[b]{2}{*}{ Zone } & \multirow[b]{2}{*}{ Route Type } & \multicolumn{6}{|c|}{ Boarding Rides } \\
\hline 2 & & & & & AMPK & Day & \multicolumn{3}{|c|}{ PMPK EVN Night } & Total \\
\hline 3 & 10 & 0 & 0 & Radial & 25 & 186 & 175 & 49 & 18 & 453 \\
\hline 4 & 10 & 1 & 0 & Radial & 27 & 65 & 26 & 2 & 6 & 126 \\
\hline 5 & 10 & 0 & 1 & Radial & 99 & 75 & 35 & 23 & 4 & 236 \\
\hline 6 & 10 & 1 & 1 & Radial & 96 & 108 & 41 & 8 & 36 & 289 \\
\hline 7 & 110 & 0 & 0 & Radial & 68 & 342 & 298 & 39 & 20 & 767 \\
\hline 8 & 110 & 1 & 0 & Radial & 3 & 31 & 47 & 0 & 0 & 81 \\
\hline 9 & 110 & 0 & 1 & Radial & 33 & 144 & 39 & 10 & 9 & 235 \\
\hline 10 & 110 & 1 & & Radial & 167 & 220 & 55 & 12 & 61 & 515 \\
\hline 11 & 110 & 0 & 2 & Radial & 14 & 64 & 47 & 13 & 10 & 148 \\
\hline 12 & 110 & 1 & 2 & Radial & 134 & 146 & 27 & 15 & 74 & 396 \\
\hline 13 & 110 & 0 & 3 & Radial & 0 & 4 & 14 & 2 & 0 & 20 \\
\hline 14 & 110 & 1 & 3 & Radial & 34 & 47 & 8 & 9 & 27 & 125 \\
\hline 15 & 12 & 0 & 0 & Trunk & 127 & 784 & 639 & 113 & 148 & 1811 \\
\hline 16 & 12 & 1 & 0 & Trunk & 29 & 336 & 118 & 31 & 33 & 547 \\
\hline 17 & 12 & 0 & 1 & Trunk & 10 & 32 & 15 & 10 & 9 & 76 \\
\hline 18 & 12 & 1 & 1 & Trunk & 16 & 61 & 5 & 3 & 15 & 100 \\
\hline 19 & 12 & 0 & 2 & Trunk & 23 & 130 & 36 & 9 & 21 & 219 \\
\hline 20 & 12 & 1 & 2 & Trunk & 464 & 346 & 101 & 49 & 189 & 1149 \\
\hline 21 & 12 & 0 & 3 & Trunk & 16 & 64 & 34 & 14 & 28 & 156 \\
\hline 22 & 12 & 1 & 3 & Trunk & 190 & 261 & 92 & 34 & 236 & 813 \\
\hline 23 & 112 & 0 & 0 & Radial & 79 & 619 & 363 & 105 & 186 & 1352 \\
\hline 24 & 112 & 1 & 0 & Radial & 5 & 1 & 1 & 2 & 16 & 25 \\
\hline 25 & 112 & 0 & 1 & Radial & 36 & 233 & 62 & 25 & 51 & 407 \\
\hline 26 & 112 & 1 & 1 & Radial & 125 & 331 & 105 & 44 & 117 & 722 \\
\hline 27 & 112 & 0 & 2 & Radial & 69 & 290 & 77 & 47 & 92 & 575 \\
\hline 28 & 112 & 1 & 2 & Radial & 366 & 681 & 179 & 128 & 327 & 1681 \\
\hline 29 & 115 & 0 & 0 & Radial & 160 & 716 & 406 & 152 & 222 & 1656 \\
\hline 30 & 115 & 1 & 0 & Radial & 12 & 154 & 74 & 46 & 27 & 313 \\
\hline 31 & 115 & 0 & 1 & Radial & 35 & 179 & 66 & 36 & 52 & 368 \\
\hline 32 & 115 & 1 & 1 & Radial & 382 & 844 & 258 & 139 & 271 & 1894 \\
\hline 33 & 15 & 0 & 0 & Radial & 55 & 508 & 398 & 136 & 143 & 1240 \\
\hline 34 & 15 & 1 & 0 & Radial & 1 & 26 & 12 & 8 & 0 & 47 \\
\hline 35 & 15 & 0 & 1 & Radial & 69 & 189 & 128 & 32 & 60 & 478 \\
\hline 36 & 15 & 1 & 1 & Radial & 300 & 531 & 121 & 53 & 191 & 1196 \\
\hline 37 & 15 & 0 & 2 & Radial & 81 & 193 & 74 & 33 & 40 & 421 \\
\hline 38 & 15 & 1 & & Radial & 397 & 506 & 144 & 89 & 231 & 1367 \\
\hline 39 & 15 & 0 & 3 & Radial & 3 & 19 & 19 & 3 & 14 & 58 \\
\hline 40 & 15 & 1 & 3 & Radial & 40 & 163 & 83 & 57 & 58 & 401 \\
\hline 41 & 17 & 0 & & Radial & 227 & 676 & 239 & 98 & 252 & 1492 \\
\hline 42 & 17 & 1 & 0 & Radial & 39 & 92 & 49 & 9 & 26 & 215 \\
\hline 43 & 17 & 0 & & Radial & 23 & 93 & 25 & 10 & 43 & 194 \\
\hline 44 & 17 & 1 & & Radial & 246 & 660 & 228 & 45 & 125 & 1304 \\
\hline 45 & 17 & 0 & & Radial & 5 & 11 & 11 & 5 & 4 & 36 \\
\hline 46 & 17 & 1 & & Radial & 53 & 113 & 22 & 9 & 73 & 270 \\
\hline 47 & & & & & & & & & & \\
\hline 48 & & & & et is on & Urb & Stt & s, Pc & ind $s$ & te I & rsity \\
\hline 49 & & & & & & & & & & \\
\hline
\end{tabular}


APPENDIX A Sample of Route-Segment Level Data Base (continued)

172

\begin{tabular}{|c|c|c|c|c|c|c|c|c|}
\hline $\bar{A}$ & $K$ & $L$ & $\bar{M}$ & $N$ & 0 & $\mathbf{P}$ & $\overline{\mathbf{Q}}$ & $\mathbf{R}$ \\
\hline 1 & \multirow{2}{*}{\multicolumn{2}{|c|}{$\begin{array}{l}\text { Allighting Fron } \\
\text { AMPK Day }\end{array}$}} & Complen & nentary & Routes & Population in & Population on & POP \% in \\
\hline 2 & & & PMPK & EVN & Night & Overlap area & Competing Routes & Ovlap area \\
\hline 3 & 4 & 37 & 20 & 1 & 3 & 43786 & 44902 & 0.9751 \\
\hline 4 & 17 & 39 & 8 & 1 & 5 & 43786 & 44902 & 0.9751 \\
\hline 5 & 26 & 203 & 81 & 32 & 30 & 10840 & 26241 & 0.4131 \\
\hline 6 & 40 & 132 & 35 & 12 & 12 & 10840 & 26241 & 0.4131 \\
\hline 7 & 0 & 0 & 0 & 0 & 0 & 15557 & 24991 & 0.6225 \\
\hline 8 & 0 & 0 & 0 & 0 & 0 & 15557 & 24991 & 0.6225 \\
\hline 9 & 5 & 51 & 8 & 10 & 8 & 2598 & 4892 & 0.5311 \\
\hline 10 & 10 & 25 & 15 & 5 & 3 & 2598 & 4892 & 0.5311 \\
\hline 11 & 22 & 140 & 52 & 29 & 30 & 6563 & 39250 & 0.1672 \\
\hline 12 & 27 & 102 & 41 & 11 & 31 & 6563 & 39250 & 0.1672 \\
\hline 13 & 0 & 0 & 0 & 0 & 0 & 4549 & 11057 & 0.4114 \\
\hline 14 & 0 & 6 & 9 & 5 & 2 & 4549 & 11057 & 0.4114 \\
\hline 15 & 0 & 0 & 0 & 0 & 0 & 13254 & 13254 & 1.0000 \\
\hline 16 & 0 & 0 & 0 & 0 & 0 & 13254 & 13254 & 1.0000 \\
\hline 17 & 0 & $\mathbf{0}$ & 0 & 0 & 0 & 6372 & 11712 & 0.5441 \\
\hline 18 & 0 & $\mathbf{0}$ & 0 & 0 & 0 & 6372 & 11712 & 0.5441 \\
\hline 19 & 0 & 0 & 0 & 0 & 0 & 3835 & 14011 & 0.2737 \\
\hline 20 & 3 & 52 & 30 & 4 & 6 & 3835 & 14011 & 0.2737 \\
\hline 21 & 5 & 24 & 26 & 9 & 14 & 0 & 0 & 0.0001 \\
\hline 22 & 7 & 25 & 3 & 1 & 4 & 0 & 0 & 0.0001 \\
\hline 23 & 0 & 0 & 0 & 0 & 0 & 30440 & 32435 & 0.9385 \\
\hline 24 & 0 & 0 & 0 & 0 & 0 & 30440 & 32435 & 0.9385 \\
\hline 25 & 16 & 66 & 21 & 7 & 18 & 16375 & 17815 & 0.9192 \\
\hline 26 & 1 & 8 & 5 & 2 & 1 & 16375 & 17815 & 0.9192 \\
\hline 27 & 106 & 269 & 96 & 49 & 99 & 40025 & 73368 & 0.5455 \\
\hline 28 & 130 & 180 & 55 & 32 & 77 & 40025 & 73368 & 0.5455 \\
\hline 29 & 0 & 0 & 0 & 0 & 0 & 7062 & 8610 & 0.8202 \\
\hline 30 & 0 & 0 & 0 & 0 & 0 & 7062 & 8610 & 0.8202 \\
\hline 31 & 0 & 0 & 0 & 0 & 0 & 23029 & 27888 & 0.8258 \\
\hline 32 & 16 & 37 & 14 & 10 & 13 & 23029 & 27888 & 0.8258 \\
\hline 33 & 0 & 0 & 0 & 0 & 0 & 0 & 0 & 0.0001 \\
\hline 34 & 0 & 0 & 0 & 0 & 0 & 0 & 0 & 0.0001 \\
\hline 35 & 18 & 19 & 8 & 7 & 4 & 5860 & 16604 & 0.3529 \\
\hline 36 & 2 & 13 & 17 & 8 & 0 & 5860 & 16604 & 0.3529 \\
\hline 37 & 35 & 164 & 51 & 29 & 51 & 5739 & 29247 & 0.1962 \\
\hline 38 & 23 & 175 & 37 & 11 & 48 & 5739 & 29247 & 0.1962 \\
\hline 39 & 67 & 151 & 56 & 27 & 46 & 3334 & 3660 & 0.9109 \\
\hline 40 & 141 & 162 & 82 & 38 & 93 & 3334 & 3660 & 0.9109 \\
\hline 41 & 4 & 37 & 20 & 1 & 3 & 49443 & 49443 & 1.0000 \\
\hline 42 & 17 & 39 & 8 & 1 & 5 & 49443 & 49443 & 1.0000 \\
\hline$\overline{43}$ & 0 & 3 & 0 & 0 & 0 & 15611 & 21543 & 0.7246 \\
\hline 44 & 3 & 17 & 4 & 2 & 2 & $1561 \mathrm{l}$ & 21543 & 0.7246 \\
\hline 45 & 13 & 83 & 27 & 14 & 24 & 4813 & 36889 & 0.1305 \\
\hline 46 & 0 & 1 & 0 & 0 & 0 & 4813 & 36889 & 0.1305 \\
\hline
\end{tabular}


APPENDIX A Sample of Route-Segment Level Data Base (continued)

\begin{tabular}{|c|c|c|c|c|c|c|c|c|c|c|c|}
\hline A & $\mathbf{S}$ & $\mathbf{T}$ & $\mathbf{U}$ & $\mathbf{V}$ & $w$ & $\mathbf{X}$ & $\mathbf{Y}$ & $z$ & AA & $\mathbf{A B}$ & AC \\
\hline 1 & \multicolumn{6}{|c|}{ Borading Rides on Competing Routes } & \multicolumn{5}{|c|}{ Frequancy on Competing Routes } \\
\hline 2 & AMPK & DAY & PMPK & EVN & Night & Total & AMPK & DAY & PMPK & EVN & Night \\
\hline 3 & 871 & 5326 & 4358 & 1261 & 1403 & 13328 & 32 & 25 & 31 & 24 & 17 \\
\hline 4 & 309 & 1178 & 382 & 122 & 184 & 2193 & 36 & 24 & 31 & 22 & 16 \\
\hline 5 & 238 & 1136 & 622 & 246 & 319 & 2625 & 16 & 12 & 14 & 12 & 8 \\
\hline 6 & 459 & 1426 & 392 & 154 & 247 & 2729 & 14 & 12 & 14 & 11 & 7 \\
\hline 7 & 310 & 2076 & 2227 & 467 & 612 & 5692 & 20 & 15 & 25 & 13 & 11 \\
\hline 8 & 45 & 230 & 135 & 17 & 34 & 461 & 25 & 16 & 20 & 14 & 11 \\
\hline 9 & 41 & 280 & 92 & 51 & 68 & 532 & 4 & 4 & 6 & 4 & 4 \\
\hline 10 & 298 & 355 & 87 & 23 & 220 & 983 & 6 & 4 & 5 & 4 & 4 \\
\hline 11 & 165 & 751 & 251 & 124 & 133 & 1424 & 11 & 11 & 15 & 12 & 7 \\
\hline 12 & 1213 & 1812 & 473 & 260 & 813 & 4571 & 14 & 11 & 12 & 9 & 8 \\
\hline 13 & 11 & 42 & 9 & 10 & 20 & 92 & 7 & 8 & 10 & 9 & 6 \\
\hline 14 & 71 & 178 & 50 & 22 & 112 & 433 & 10 & 8 & 9 & 6 & 6 \\
\hline 15 & 143 & 639 & 507 & 124 & 131 & 1544 & 9 & 8 & 8 & 8 & 5 \\
\hline 16 & 13 & 39 & 26 & 11 & 41 & 130 & 9 & 8 & 9 & 8 & 5 \\
\hline 17 & 74 & 316 & 149 & 52 & 66 & 657 & 9 & 8 & 8 & 8 & 5 \\
\hline 18 & 310 & 553 & 177 & 71 & 213 & 1324 & 9 & 8 & 9 & 8 & 5 \\
\hline 19 & 60 & 181 & 37 & 13 & 27 & 318 & 5 & 4 & 4 & 3 & 3 \\
\hline 20 & 276 & 627 & 130 & 40 & 168 & 1241 & 5 & 4 & 4 & 2 & 2 \\
\hline 21 & 0 & 0 & 0 & 0 & 0 & 0 & 0 & 0 & 0 & 0 & 0 \\
\hline 22 & 0 & 0 & 0 & 0 & 0 & 0 & 0 & 0 & 0 & 0 & 0 \\
\hline 23 & 478 & 2257 & 1580 & 430 & 432 & 5177 & 21 & 17 & 22 & 14 & 9 \\
\hline 24 & 198 & 796 & 301 & 59 & 113 & 1467 & 23 & 17 & 20 & 15 & 9 \\
\hline 25 & 157 & 304 & 102 & 40 & 47 & 650 & 18 & 13 & 19 & 13 & 6 \\
\hline 26 & 278 & 357 & 92 & 20 & 139 & 886 & 19 & 13 & 17 & 12 & 7 \\
\hline 27 & 117 & 515 & 167 & 72 & 62 & 933 & 24 & 18 & 24 & 18 & 12 \\
\hline 28 & 972 & 989 & 277 & 91 & 407 & 2736 & 26 & 18 & 22 & 16 & 14 \\
\hline 29 & 49 & 187 & 101 & 39 & 27 & 403 & 4 & 2 & 3 & 3 & 1 \\
\hline 30 & 5 & 46 & 37 & 8 & 3 & 99 & 4 & 2 & 3 & 3 & 1 \\
\hline 31 & 66 & 214 & 76 & 35 & 89 & 480 & 11 & 6 & 10 & 6 & 4 \\
\hline 32 & 432 & 1024 & 375 & 115 & 212 & 2158 & 8 & 7 & 9 & 7 & 5 \\
\hline 33 & 0 & 0 & 0 & 0 & 0 & 0 & 0 & 0 & 0 & 0 & 0 \\
\hline 34 & 0 & 0 & 0 & 0 & 0 & 0 & 0 & 0 & 0 & 0 & 0 \\
\hline 35 & 115 & 596 & 241 & 103 & 134 & 1189 & 14 & 12 & 14 & 12 & 8 \\
\hline 36 & 608 & 908 & 264 & 94 & 433 & 2307 & 15 & 12 & 14 & 12 & 8 \\
\hline 37 & 117 & 417 & 158 & 71 & 109 & 872 & 9 & 8 & 10 & 9 & 6 \\
\hline 38 & 734 & 1094 & 340 & 193 & 590 & 2951 & 10 & 8 & 9 & 8 & 6 \\
\hline 39 & 0 & 3 & 2 & 0 & 0 & 5 & 9 & 8 & 8 & 9 & 5 \\
\hline 40 & 89 & 153 & 54 & 35 & 71 & 402 & 9 & 8 & 8 & 8 & 5 \\
\hline 41 & 687 & 3330 & 1868 & 727 & 837 & 7449 & 35 & 29 & 34 & 26 & 19 \\
\hline 42 & 209 & 753 & 244 & 76 & 177 & 1459 & 37 & 28 & 34 & 25 & 17 \\
\hline 43 & 74 & 274 & 99 & 55 & 97 & 599 & 9 & 6 & 9 & 6 & 5 \\
\hline 44 & 462 & 1086 & 383 & 203 & 339 & 2473 & 8 & 7 & 9 & 7 & 5 \\
\hline 45 & 109 & 681 & 223 & 133 & 180 & 1326 & 8 & 6 & 8 & 7 & 4 \\
\hline 46 & 659 & 1341 & 421 & 225 & 483 & 3129 & 8 & 6 & 8 & 6 & 4 \\
\hline
\end{tabular}


APPENDIX A Sample of Route-Segment Level Data Base (continued)

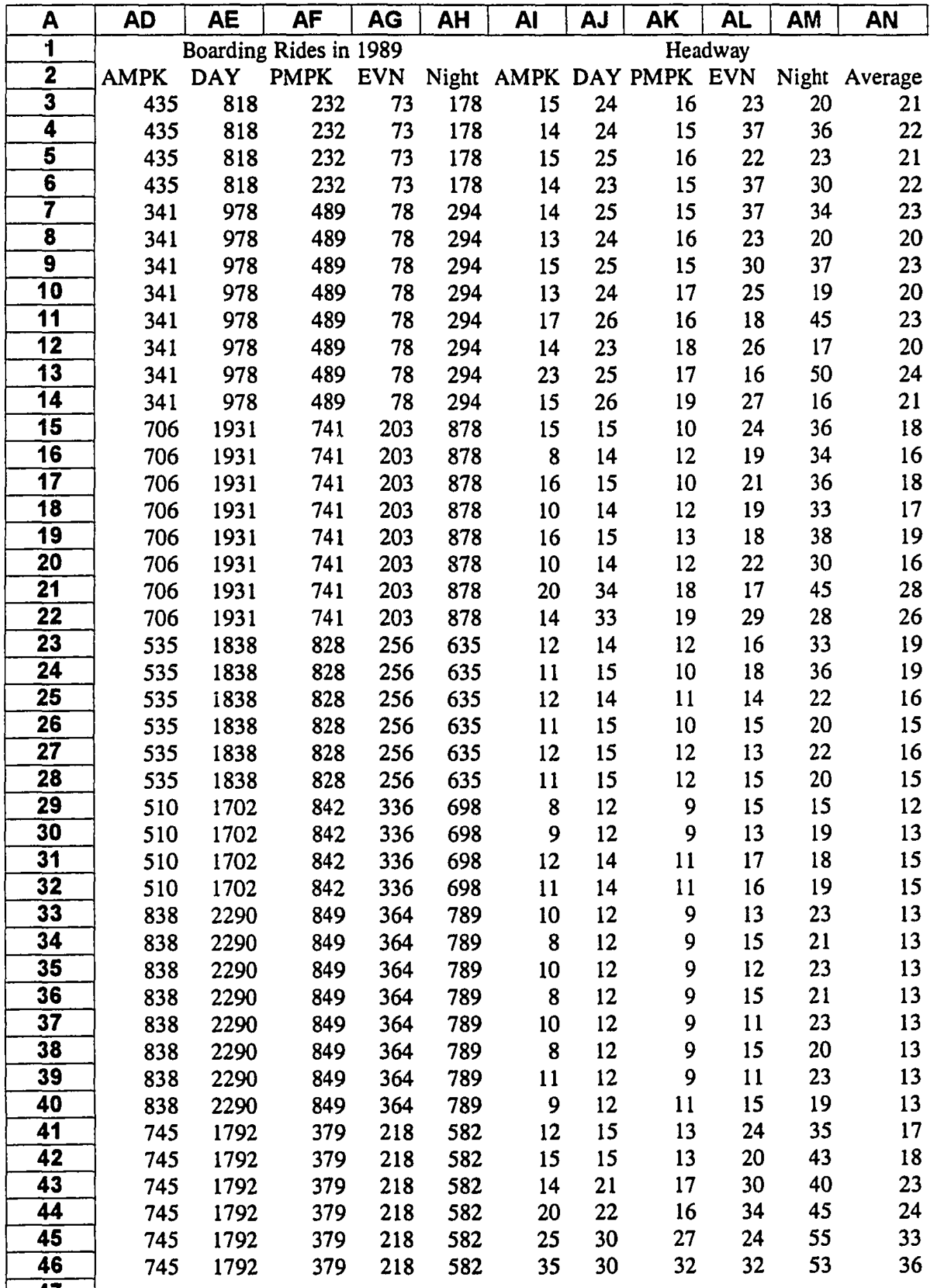


APPENDIX A Sample of Route-Segment Level Data Base (continued)

175

\begin{tabular}{|c|c|c|c|c|c|c|c|c|c|c|c|}
\hline $\mathbf{A}$ & $\overline{A O}$ & AP & $\mathbf{A Q}$ & AR & AS & AT & $\mathbf{A U}$ & $\mathbf{A V}$ & AW & $A X$ & AY \\
\hline 1 & \multicolumn{4}{|c|}{ Average Seat per Bus } & & \multicolumn{6}{|c|}{ Serving Time (Minutes) } \\
\hline 2 & AMPK & DAY & PMPK & EVN & Night & AMPK & DAY & PMPK & EVN & Night & Total \\
\hline 3 & 43 & 43 & 43 & 43 & 43 & 120 & 420 & 120 & 120 & 61 & 841 \\
\hline 4 & 43 & 43 & 43 & 43 & 43 & 120 & 420 & 120 & 120 & 88 & 868 \\
\hline 5 & 43 & 43 & 43 & 43 & 43 & 120 & 420 & 120 & 120 & 46 & 826 \\
\hline 6 & 43 & 43 & 43 & 43 & 43 & 120 & 420 & 120 & 120 & 98 & 878 \\
\hline 7 & 43 & 43 & 43 & 43 & 43 & 120 & 420 & 120 & 120 & 116 & 896 \\
\hline 8 & 43 & 43 & 43 & 43 & 43 & 120 & 420 & 120 & 120 & 61 & 841 \\
\hline 9 & 43 & 43 & 43 & 43 & 43 & 120 & 420 & 120 & 120 & 134 & 914 \\
\hline 10 & 43 & 43 & 43 & 43 & 43 & 120 & 420 & 120 & 120 & 73 & 853 \\
\hline 11 & 43 & 43 & 43 & 43 & 43 & 120 & 420 & 120 & 59 & 130 & 49 \\
\hline 12 & 43 & 43 & 43 & 43 & 43 & 120 & 420 & 120 & 120 & 84 & 64 \\
\hline 13 & 43 & 43 & 43 & 43 & 43 & 120 & 349 & 120 & 120 & 108 & 11 \\
\hline 14 & 43 & 43 & 43 & 43 & 43 & 120 & 420 & 120 & 120 & 93 & 873 \\
\hline 15 & 52 & 52 & 57 & 47 & 57 & 120 & 420 & 120 & 120 & 243 & 1023 \\
\hline 16 & 55 & 54 & 52 & 58 & 51 & 120 & 420 & 120 & 120 & 242 & 1022 \\
\hline 17 & 53 & 53 & 55 & 51 & 53 & 120 & 420 & 120 & 20 & 357 & 1137 \\
\hline 18 & 48 & 52 & 53 & 59 & 50 & 120 & 420 & 120 & 120 & 348 & 1128 \\
\hline 19 & 50 & 53 & 56 & 55 & 57 & 120 & 420 & 120 & 120 & 357 & 1137 \\
\hline 20 & 52 & 55 & 52 & 57 & 53 & 120 & 420 & 120 & 120 & 360 & 1140 \\
\hline 21 & 54 & 55 & 55 & 52 & 55 & 120 & 420 & 120 & 120 & 365 & 1145 \\
\hline 22 & 53 & 54 & 52 & 58 & 56 & 120 & 420 & 120 & 120 & 359 & 1139 \\
\hline 23 & 52 & 53 & 54 & 60 & 54 & 120 & 420 & 120 & 120 & 352 & 1132 \\
\hline 24 & 57 & 53 & 58 & 51 & 54 & 120 & 420 & 120 & 120 & 98 & 1078 \\
\hline 25 & 52 & 53 & 53 & 53 & 54 & 120 & 420 & 120 & 120 & 78 & 1158 \\
\hline 26 & 55 & 53 & 58 & 51 & 55 & 120 & 420 & 120 & 120 & 3 & 1133 \\
\hline 27 & 5 & 54 & 54 & 53 & 53 & 120 & 420 & 120 & 120 & 382 & 1162 \\
\hline 28 & 55 & 52 & 56 & 53 & 54 & 120 & 420 & 120 & 120 & 363 & 1143 \\
\hline 29 & 43 & 43 & 43 & 43 & 43 & 120 & 420 & 120 & 120 & 316 & 1096 \\
\hline 30 & 43 & 43 & 43 & 43 & 43 & 120 & 420 & 120 & 120 & 322 & 1102 \\
\hline 31 & 43 & 43 & 43 & 43 & 43 & 120 & 420 & 120 & 1 & 2 & 1152 \\
\hline 32 & 43 & 43 & 43 & 43 & 4 & 120 & 420 & 120 & 1 & 3 & 1173 \\
\hline 33 & 43 & 43 & 43 & 43 & 43 & 120 & 420 & 120 & 120 & 307 & 1087 \\
\hline 34 & 43 & 43 & 43 & 43 & 43 & 120 & 420 & 120 & 120 & 301 & 1081 \\
\hline 35 & 43 & 43 & 43 & 43 & 43 & 120 & 420 & 120 & 120 & 352 & 1132 \\
\hline 36 & 43 & 43 & 4 & 4 & 4 & 1 & 420 & 120 & 1 & 14 & 1124 \\
\hline 37 & 43 & 43 & 4. & 4 & 43 & 120 & 420 & 120 & 120 & 66 & 1146 \\
\hline 38 & 43 & 43 & 43 & 43 & 43 & 120 & 420 & 120 & 120 & 360 & 1140 \\
\hline 39 & 43 & 43 & 43 & 43 & 43 & 120 & 420 & 120 & 120 & 360 & 1140 \\
\hline 40 & 43 & 43 & 43 & 43 & 43 & 120 & 420 & 120 & 120 & 351 & 1131 \\
\hline 41 & 43 & 43 & 43 & 43 & 43 & 120 & 420 & 120 & 120 & 223 & 1003 \\
\hline 42 & 43 & 43 & $4 ?$ & 43 & 43 & 120 & 420 & 120 & 120 & 10 & 990 \\
\hline 43 & 43 & 43 & 43 & 43 & 43 & 120 & 420 & 120 & 120 & 362 & 1142 \\
\hline 44 & 43 & 43 & 43 & 43 & 43 & 120 & 420 & 120 & 120 & 364 & 1144 \\
\hline 45. & 43 & 43 & 43 & 43 & 43 & 120 & 420 & 120 & 120 & 302 & 1082 \\
\hline$\overline{46}$ & 43 & 43 & 43 & 43 & 43 & 120 & 420 & 120 & 12 & 2 & 113 \\
\hline
\end{tabular}


APPENDIX A Sample of Route-Segment Level Data Base (continued)

176

\begin{tabular}{|c|c|c|c|c|c|c|c|c|}
\hline A & $\mathbf{A Z}$ & BA & BB & $B C$ & BD & $\mathbf{B E}$ & $\mathbf{B F}$ & BG \\
\hline 1 & Park-lot & Population & Popu- & Employ- & AREA & HH with & HH \% wit & High School \\
\hline 2 & Capacity & Downstream & lation & ment & (Acres) & INC $<25$ & INC $<25 k$ & Students \\
\hline 3 & 0 & 17159 & 6838 & 77922 & 550.75 & 3041 & 0.7284 & 0 \\
\hline 4 & 0 & 0 & 6838 & 77922 & 550.75 & 3041 & 0.7284 & 0 \\
\hline 5 & 0 & 10321 & 10321 & 15232 & 1011.65 & 31 & 0.1134 & 0 \\
\hline 6 & 0 & 0 & 10321 & 15232 & 1011.65 & 31 & 0.1134 & 0 \\
\hline 7 & 0 & 31329 & 2954 & 68145 & 331.45 & 1309 & 0.7875 & 0 \\
\hline 8 & 0 & 0 & 2954 & 68145 & 331.45 & 1309 & 0.7875 & 0 \\
\hline 9 & 0 & 28375 & 9509 & 10782 & 959.14 & 2731 & 0.5848 & 1350 \\
\hline 10 & 0 & 0 & 9509 & 10782 & 959.14 & 2731 & 0.5848 & 1350 \\
\hline 11 & 0 & 18866 & 12125 & 2884 & 1210.41 & 2940 & 0.5331 & 0 \\
\hline 12 & 0 & 0 & 12125 & 2884 & 1210.41 & 2940 & 0.5331 & 0 \\
\hline 13 & 0 & 6741 & 6741 & 629 & 1223.66 & 938 & 0.3858 & 0 \\
\hline 14 & 0 & 0 & 6741 & 629 & 1223.66 & 938 & 0.3858 & 0 \\
\hline 15 & 0 & 26466 & 6627 & 76689 & 526.51 & 3033 & 0.7372 & 0 \\
\hline 16 & 0 & 0 & 6627 & 76689 & 526.51 & 3033 & 0.7372 & 0 \\
\hline 17 & 0 & 19839 & 4403 & 10159 & 614.22 & 1798 & 0.6902 & 1403 \\
\hline 18 & 0 & 0 & 4403 & 10159 & 614.22 & 1798 & 0.6902 & 1403 \\
\hline 19 & 320 & 15436 & 14708 & 9904 & 1788.34 & 2715 & 0.4172 & 0 \\
\hline 20 & 320 & 0 & 14708 & 9904 & 1788.34 & 2715 & 0.4172 & 0 \\
\hline 21 & 0 & 728 & 728 & 258 & 87.00 & 209 & 0.6732 & 0 \\
\hline 22 & 0 & 0 & 728 & 258 & 87.00 & 209 & 0.6732 & 0 \\
\hline 23 & 0 & 26367 & 5687 & 67673 & 411.01 & 2768 & 0.6841 & 0 \\
\hline 24 & 0 & 0 & 5687 & 67673 & 411.01 & 2768 & 0.6841 & 0 \\
\hline 25 & 0 & 20680 & 2252 & 9259 & 426.12 & 580 & 0.4348 & 0 \\
\hline 26 & 0 & 0 & 2252 & 9259 & 426.12 & 580 & 0.4348 & 0 \\
\hline 27 & 0 & 18428 & 18428 & 7408 & 3158.39 & 2979 & 0.3496 & 1527 \\
\hline 28 & 0 & 0 & 18428 & 7408 & 3158.39 & 2979 & 0.3496 & 1527 \\
\hline 29 & 0 & 17195 & 3531 & 70411 & 340.36 & 1681 & 0.8580 & 0 \\
\hline 30 & 0 & 0 & 3531 & 70411 & 340.36 & 1681 & 0.8580 & 0 \\
\hline 31 & 0 & 13664 & 13664 & 14282 & 1009.46 & 6111 & 0.6333 & 1723 \\
\hline 32 & 0 & 0 & 13664 & 14282 & 1009.46 & 6111 & 0.6333 & 1723 \\
\hline 33 & 0 & 26311 & 1806 & 50191 & 224.85 & 688 & 0.8768 & 0 \\
\hline 34 & 0 & 0 & 1806 & 50191 & 224.85 & 688 & 0.8768 & 0 \\
\hline 35 & 0 & 24505 & 7805 & 8928 & 659.36 & 3053 & 0.7016 & 762 \\
\hline 36 & 0 & 0 & 7805 & 8928 & 659.36 & 3053 & 0.7016 & 762 \\
\hline 37 & 0 & 16700 & 13772 & 2875 & 1294.40 & 3047 & 0.4980 & 0 \\
\hline 38 & 0 & 0 & 13772 & 2875 & 1294.40 & 3047 & 0.4980 & 0 \\
\hline 39 & 865 & 2928 & 2928 & 4469 & 555.50 & 733 & 0.5362 & 0 \\
\hline 40 & 865 & 0 & 2928 & 4469 & 555.50 & 733 & 0.5362 & 0 \\
\hline 41 & 0 & 23176 & 7505 & 83779 & 622.22 & 3336 & 0.7258 & 0 \\
\hline 42 & 0 & 0 & 7505 & 83779 & 622.22 & 3336 & 0.7258 & 0 \\
\hline 43 & 0 & 15671 & 12272 & 19535 & 1157.23 & 5998 & 0.6709 & 478 \\
\hline 44 & 0 & 0 & 12272 & 19535 & 1157.23 & 5998 & 0.6709 & 478 \\
\hline 45 & 0 & 3399 & 3399 & 7203 & 1618.20 & 1024 & 0.5966 & 0 \\
\hline 46 & 0 & 0 & 3399 & 7203 & 1618.20 & 1024 & 0.5966 & 0 \\
\hline
\end{tabular}

